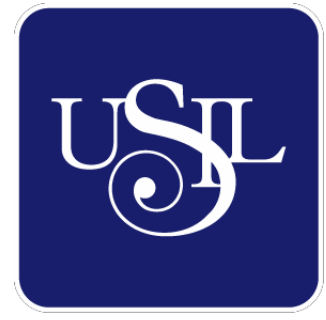

UNIVERSIDAD

SAN IGNACIO

DE LOYOLA

FACULTAD DE HUMANIDADES

Carrera de Arte y Diseño Empresarial

\title{
EVASIÓN DE IMPUESTOS GENERADA POR LA INFORMALIDAD COMERCIAL AMBULATORIA EN LOS ALREDEDORES DEL MERCADO SAN FRANCISCO UBICADO EN EL DISTRITO DE VILLA MARIA DEL TRIUNFO
}

Tesis para optar el Título Profesional de Licenciado en Arte y Diseño Empresarial

ANGIE ANTONELLA SARDA TALLEDO

Asesor:

Mtro. Rafael Ernesto Vivanco Álvarez

Lima - Perú

2019 
Dedicado a mis padres por haberme

ayudado en todo el tiempo

de mi carrera y en esta titulación. 
Agradezco a todas las personas

que me apoyaron en todo este proceso

para la realización de mi tesis y mi implementación. 


\section{Resumen}

La presente investigación permitió llevar a cabo un estudio sobre "Evasión de impuestos generada por la informalidad comercial ambulatoria en los alrededores del Mercado San Francisco ubicado en el distrito de Villa María del Triunfo". El distrito de Villa María del Triunfo con una población de 448,545 habitantes (INEI 2015), cuenta con 7000 ambulantes aproximadamente (Municipalidad de VMT).

La informalidad comercial, se define como trabajo fuera de la ley, es un sector económico que no está en las estadísticas oficiales, por lo tanto no queda registrado en ningún papel ya que los pagos que se hacen, son en efectivo en consecuencia no pagan impuestos, ni a la municipalidad, ni a la SUNAT. Los comerciantes informales están obligados así como cualquier otro ciudadano a pagar los impuestos porque todos utilizamos los servicios públicos; al evadir sus tributos perjudican no solo al estado, sino a todo el país en general. El Estado al no recibir esos tributos, ya no podrá contar con los recursos necesarios para hacer más obras y tendrá que crear más impuestos perjudicando a los que sí contribuyen. Los informales deben de tener en cuenta que el pago de impuestos, no es una reducción de sus entradas, sino que es una contribución para el desarrollo del país. Asimismo, las instituciones del Estado deben ser transparentes en la forma como manejan los recursos para que los contribuyentes acepten la carga tributaria impuesta para ellos.

Se buscó saber por qué el comerciante ambulante no se formaliza, si es por factores internos personales, el desempleo o lo hacen de forma premeditada ya que al evadir impuestos ellos tienen más ingresos. Además hay factores externos para que los comerciantes informales no se formalicen como las políticas de formalización y tributación y sus costos que muchas veces no están al alcance de los comerciantes informales. También, se trató el tema como un problema social y los riesgos a los que se enfrentan por estar en las calles expuestos a la persecución y confiscación de sus mercaderías. Estar dentro del sector informal implica estar al margen de las cargas tributarias y normas legales, pero también implica no tener el respaldo y todo lo que el estado puede otorgar. 
Se buscó, concientizar a la gente en general para que al comprar lo realicen en lugares formales, mostrándoles las obras que el Estado deja de hacer por la evasión de impuestos de los comerciantes informales.

\begin{abstract}
The present investigation describes about the study done on the "tax evasion generated by the informal street commerce in the surroundings of the San Francisco Market located in the Villa María del Triunfo district". This district counts with a population of 448,545 inhabitants (INEI 2015), has approximately 7,000 street vendors (Municipality of VMT).

The informal commerce, defined as work outside the law, is an economic activity that is not register in the official statistics, therefore it is not recorded on any paper since the payments are in cash which result in the seller not paying taxes neither to the municipality, nor to the SUNAT. Informal merchants should, as well as any other citizen, pay taxes because we all use public services and by evading doing so they harm not only the district, but the entire country. The district, by not receiving these taxes, will no longer be able have the necessary resources to do more public work and would have to increase the current tax amount, affecting to those who do contribute. These people involved on informal commerce must understand that taxes are not a reduction of their income, but is a contribution to the development of the country. Likewise, the state institutions must be transparent in the way they manage the resources so that the population can have information about the works done with their taxes.
\end{abstract}

This study searched for an explanation about why the street seller is not formalized, if it is due to personal internal factors, unemployment or they do it on purpose since by evading taxes they will have more income. There are also external factors that could explain why informal traders are not formalized, such as formalization and tax policies and their costs, which are often not affordable by these informal traders. Also, the issue can be described as a social problem because of the risks they face for being on the streets exposed to the confiscation of their merchandise. Being within the informal sector implies being outside the tax burdens 
and legal norms, but it also implies not having the support and everything the district and the state can offer.

This project wanted to make people aware about this social issue so that when they do shopping they should do it in formal local places, and showing them the works that the state stops doing because the tax evasion of the informal trading. 


\section{Introducción}

La informalidad es un problema que viene de mucho tiempo atrás, ligado a la economía peruana y del que no hay visos de solución. Muchos gobiernos han tratado de acabar con este trabajo fuera de la ley y muchos estudios se han hecho sobre el tema, pero el problema todavía continúa.

En el presente trabajo, se investigará la evasión de impuestos generada por la informalidad comercial ambulatoria en los alrededores del Mercado San Francisco ubicado en el distrito de Villa María del Triunfo el cual se viene dando desde hace casi 20 años aproximadamente y se analizará por qué los comerciantes informales no buscan formalizarse, ya sea a través de la municipalidad o a través de la SUNAT, porque esperan tantos años para hacerlo y qué trabas encuentran en el camino.

Cada ambulante es un mundo aparte, cada uno, tiene sus problemas y sus historias de cómo comenzó en este trabajo informal, ellos también en ese camino arrastran a su familia a la informalidad, muchos están conformados por familias completas.

Este problema a través de los años y con varios gobiernos municipales, no ha tenido solución y más bien ha ido en aumento. Esto se debe a varios factores migración interna, desempleo, falta de autoridad de los gobernantes locales, corrupción municipal, etc. El comercio informal ambulatorio, afecta a todo el país ya que los informales al evadir sus impuestos, no se pueden realizar más obras.

Se verá también el rol de la sociedad ante esta problemática, que puede hacer el ciudadano de a pie para ayudar a que este problema no continúe, todos estos temas y más trataremos de analizar en esta investigación. 


\section{INDICE}

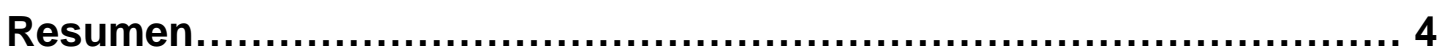

Introducción....................................................................... 5

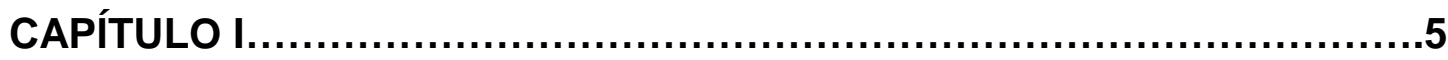

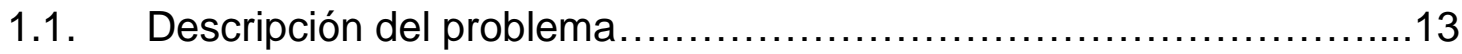

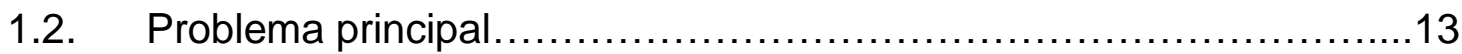

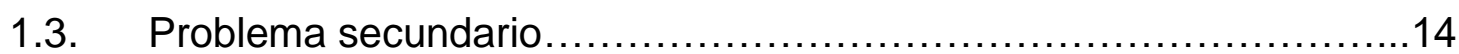

\section{CAPÍTULO II 14}

2.1. Justificación de la investigación.......................................16

2.2. Objetivo Principal....................................................

2.3. Objetivos Secundarios.............................................................17

\section{CAPÍTULO III}

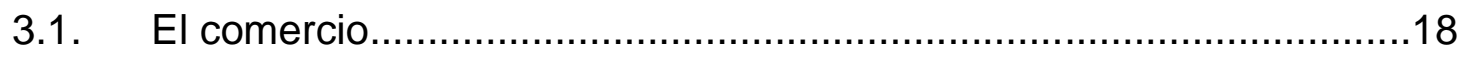

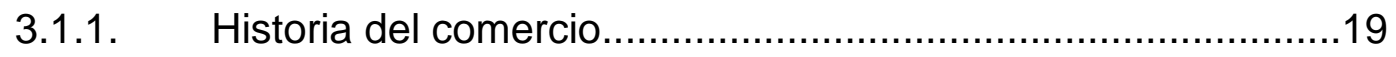

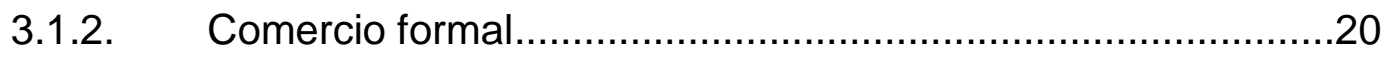

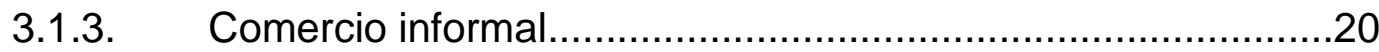

A. Causas del comercio informal.............................................26

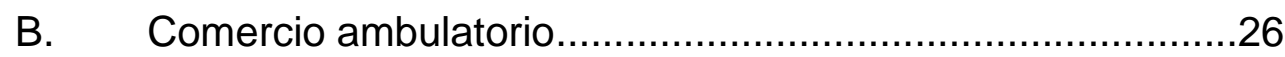

C. Clases de comercio ambulatorio...........................................27

3.1.4. Los ambulantes como problema social.................................28

3.1.5. Comercio ambulatorio principales zonas informales en Lima...29

3.2. Distrito de Villa María del Triunfo......................................................

3.2.1. Historia y antecedentes.....................................................

3.2.2. Los ambulantes en el distrito de Villa María del Triunfo...........31

3.2.3. Principales rubros del comercio informal................................31

A. Comida 

B. Ropa y zapatos
C. Otros

3.2.4. Problemas que afrontan los comerciantes informales. .33
A. Confiscación y pérdidas materiales
B. Incremento de la delincuencia
C. Riesgos ocupacionales de los comerciantes informales

3.2.5. Rol de la sociedad ante esta problemática ............................35

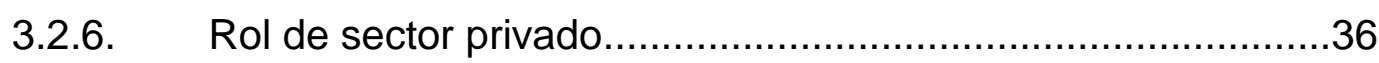

3.3. Influencia de la migración en la informalidad comercial......................36

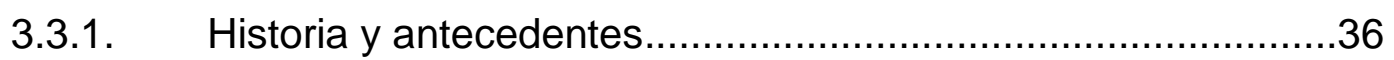

3.4. Estadísticas de los ingresos por trabajo informal...............................37

3.5. Mercado San francisco de Villa María del Triunfo...............................38

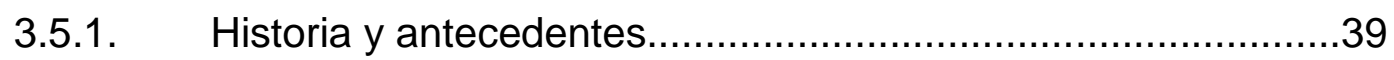

3.5.2. Problemática de los Ambulantes alrededor del Mercado.........40

3.6. Municipalidad de Villa María del Triunfo.............................................41

3.6.1. Leyes municipales y ordenanzas...........................................41

3.6.2. Requisitos para formalizarse ................................................ 42

3.6.3. Acciones tomadas hacia los ambulantes informales ..............43

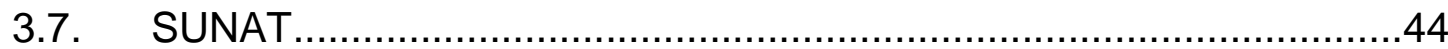

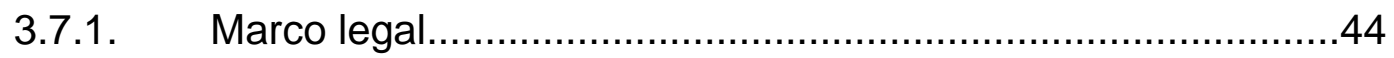

3.7.2. Acciones gubernamentales contra la informalidad comercial..46

3.7.3. Proceso para formalizarse...................................................48

3.7.4. Evasión de Impuestos generada por la informalidad comercial

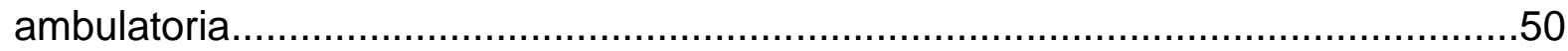

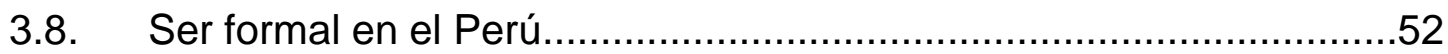

3.8.1. Importancia de ser comerciante formal................................52

3.8.2. Costos y tiempos para constituir un negocio...........................54

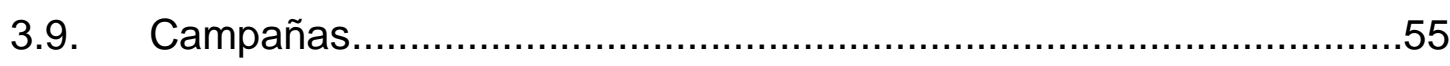

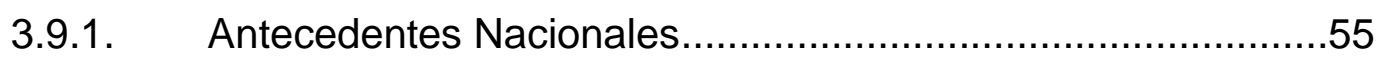

3.9.2. Antecedentes Internacionales.............................................56

4.0. Diseño gráfico como instrumento de información....................................58

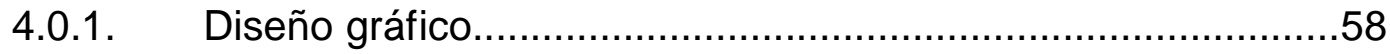


4.0.2. Diseño de información (infografía)....................................59

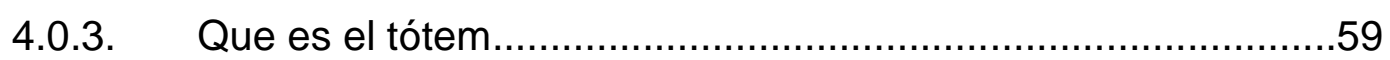

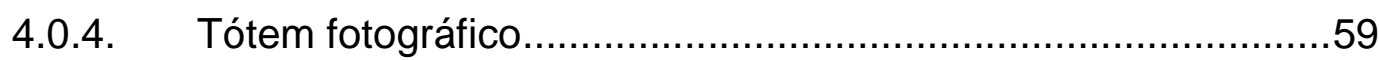

CAPÍTULO IV.............................................................................................60

4.1. Estructura del Proyecto......................................................60

4.1.1. Concepto del proyecto..................................................60

4.1.2. Nombre del proyecto...................................................60

4.1.3. Fundamentación del proyecto......................................60

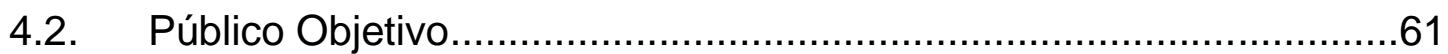

4.2.1. Actores involucrados en el problema..................................61

4.2.2. Fundamentación del público objetivo elegido.........................62

4.2.3. Descripción del público objetivo..........................................62

4.3. Levantamiento de información..................................................63

4.3.1. Fotografías de la situación del problema.............................66

4.3.2. Entrevistas a los protagonistas del problema .....................66

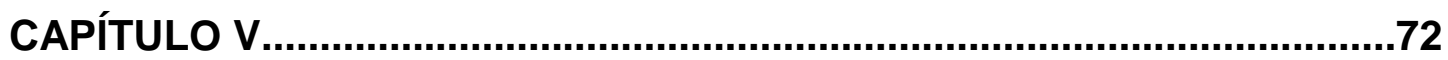

5.1. Análisis del Diseño en general............................................72

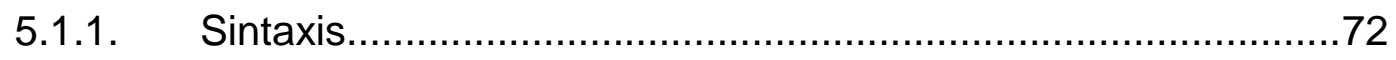

5.1.2. Estética.................................................................. 73

5.1.3. Simbología.............................................................. 73

5.1.4. Pragmatismo...............................................................

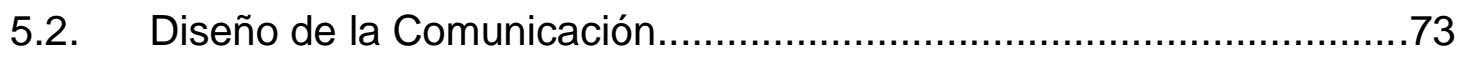

5.2.1. Fundamentación del diseño.........................................73

5.2.2. Propuesta gráfica......................................................... 73

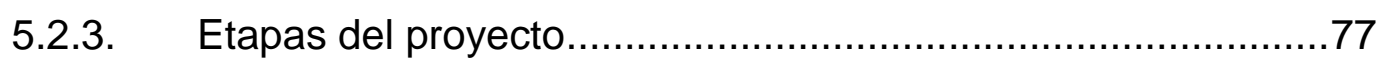

CAPÍTULO VI.......................................................................................78

6.1. Análisis de los resultados...................................................... 78

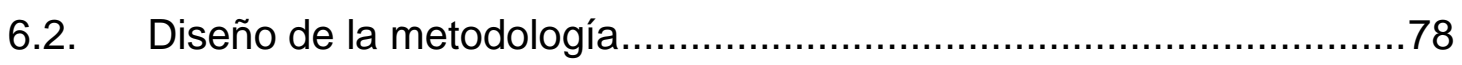

6.3. Evaluación de la metodología..............................................79 
6.4. Registro de la implementación...............................................81

6.5. Documentos que acrediten evaluación de pares...............................85

CAPÍTULO VII............................................................................................90

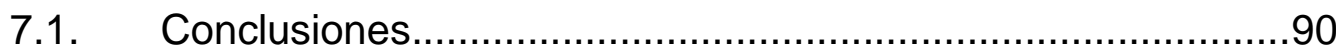

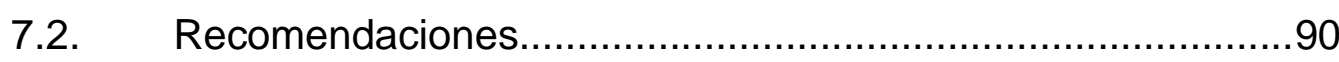

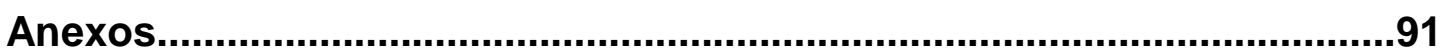

Referentes bibliográficos..................................................................112 


\section{Lista de Tablas}

Figura 1. Remuneración mensual promedio por sector formal e informal.............37

Figura 2. Participación del sector informal en el Perú............................. 37

Figura 3. Perú: ingreso por trabajo per cápita mensual...........................38

Figura 4. Unidades productivas según grafo de informalidad.....................38 


\section{Lista de Figuras}

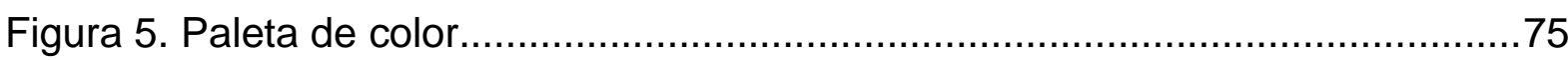

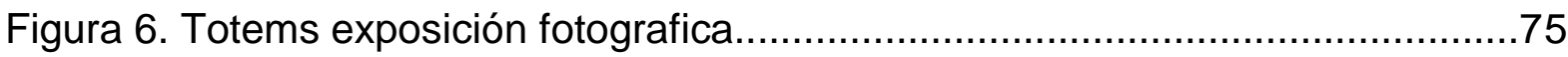

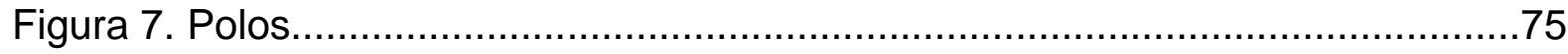

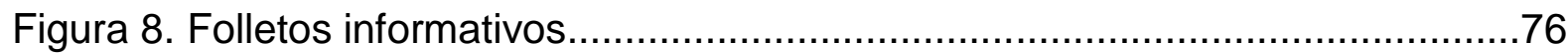

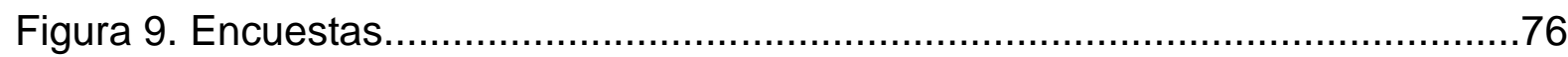

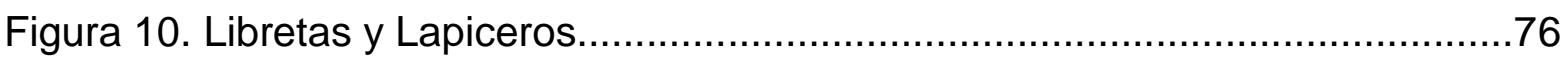

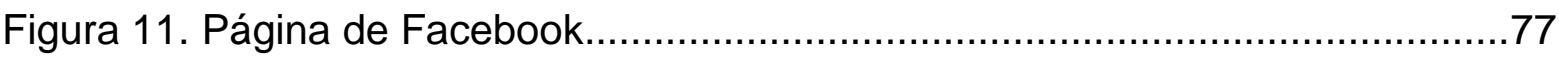

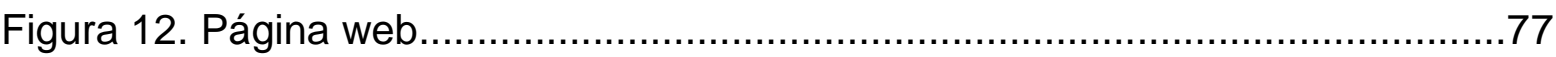




\section{CAPÍTULO I}

\subsection{Descripción del problema}

La informalidad comercial se define como trabajo fuera de la ley, la cual puede empezar de forma inesperada, al no encontrar el informal muchas oportunidades de trabajo. Este trabajo los expone a muchos riesgos en la calle, persecución por parte de los fiscalizadores, robos por parte de la delincuencia, problemas de salud, entre otros. Los informales no tienen ningún documento legal que los proteja, no existen para el sistema bancario y evaden impuestos lo que es perjudicial para el estado. Es un sector económico que no está en las estadísticas oficiales, por lo tanto no queda registrado en ningún papel ya que los pagos que se hacen, son en efectivo y no pagan impuestos a la municipalidad ni a la SUNAT.

En distintos países se define con diferentes nombre a la informalidad comercial por ejemplo economía informal, economía subterránea, economía paralela o simplemente mercado negro, pero significan lo mismo. En lugares como Asia, ha habido un impresionante crecimiento económico en escasos años, sin embargo, hay pocas vacantes de empleo en el sector formal, obligando a las personas a buscar trabajo informalmente como modo de ganar dinero para poder vivir para ellos y sus familias, enfrentando malas condiciones de trabajo, sin seguridad, falta de beneficios y falta de crecimiento laboral. En Norteamérica, la informalidad ha existido desde hace varios años debido generalmente a la migración de extranjeros provenientes en su mayoría de México y Centroamérica. En zonas como América Latina y el caribe casi el $50 \%$ de trabajadores trabaja en situación de informalidad (Banco Mundial, 2014). El Perú es uno de los países donde hay más trabajo informal en América Latina, llegando a un 73.3\% de informalidad comercial en el año 2017, trabajan de esa manera, porque los costos para formalizarse son elevados y ellos trabajan con un bajo capital (INEI, 2017).

Los comerciantes informales, saben a lo que se exponen en las calles y por eso muchos de ellos piensan en algún momento en formalizarse y poder salir de la 
informalidad en la que se encuentran. Sin embargo, encuentran dificultades a la hora de formalizarse ya que no cuentan con el dinero necesario, ni el tiempo suficiente para poder pagar el costo que se le pide para ser legal. Se puede esperar semanas e incluso meses para que consigan permisos y autorizaciones para la instalación de su negocio. Asimismo no solo son los trámites y permisos los que cuestan sino también se debe gastar para el alquiler de una tienda o un puesto en un mercado, el comprar las vitrinas o muebles para su local, gastos de agua, luz, etc. (Entrevistas a ambulantes, 2019). Pero en muchos casos los comerciantes informales se acostumbran por años a trabajar de esa manera ganando bien, sin pagar impuestos, ni local, ni luz, ni agua, ni otros gastos que se necesitan cuando uno ya es formal, por lo que se puede observar, es necesario analizar el problema de la evasión de impuestos generada por la Informalidad Comercial en los alrededores del Mercado San Francisco ubicada en el distrito de Villa María del Triunfo.

El propósito es que se conozca, todos los problemas que acarrea al Estado la evasión de impuestos generada por los comerciantes informales, que sepan que tramites deben hacer para formalizarse ya sea con la Municipalidad o con la SUNAT y los beneficios que obtendrán al ser formales.

\subsection{Problema principal}

Evasión de impuestos generada por la informalidad comercial ambulatoria en los alrededores del mercado San Francisco ubicado en el distrito de Villa María del Triunfo.

\subsection{Problema secundario}

Desconocimiento de las leyes tributarias que ocasionan la evasión de impuestos generada por la informalidad comercial ambulatoria en los alrededores del mercado San Francisco ubicado en el distrito de Villa María del Triunfo.

Falta de desarrollo de infraestructura pública por la evasión de impuestos generada por la informalidad comercial ambulatoria en los alrededores del mercado San Francisco ubicado en el distrito de Villa María del Triunfo. 


\section{CAPÍTULO II}

\subsection{Justificación de la investigación}

La informalidad comercial es un problema que viene desde hace mucho tiempo atrás y se da en el Perú y el Mundo, debido principalmente a los altos costos para formalizarse. Los comerciantes informales, generalmente desconocen los trámites tributarios que deben realizar para formalizarse, ya sea con la Municipalidad o con la SUNAT.

El vender en la calle sin licencia, ocasiona enfrentamientos con los inspectores municipales los cuales tratan de desalojarlos y requisarles sus mercaderías para que no regresen a trabajar, esto afecta a su capital ocasionándoles pérdidas económicas. Asimismo, el trabajar en las calles puede provocarles enfermedades ocupacionales y los hace víctimas de la delincuencia y de la inseguridad que ha crecido de manera alarmante en los últimos años en el Perú.

El no formalizarse, ocasiona que se produzca una evasión tributaria, la cual es perjudicial para el país ya que sin esos tributos no se pueden construir más pistas, colegios, hospitales y obras en general así también, no posibilita que el estado tenga los recursos para dar los servicios básicos a los pobladores y en especial a los que tienen menos. La evasión tributaria contribuye a generar más déficit fiscal el cual produce la generación de nuevos tributos, por lo tanto afecta a todos los ciudadanos y a los comerciantes formales que sí cumplen con sus obligaciones. Si el Estado no contara con suficientes recursos pedirá préstamos externos los cuales se pagarían con intereses, esto ocasionaría mayores gastos al Estado, para lo cual toda la sociedad tendría que pagar más impuestos ocasionados por los que no pagan sus obligaciones tributarias. Asimismo, se retrasaría el desarrollo económico del país, porque el Estado no podría redistribuir el dinero a partir de lo que se tributa.

El motivo de esta investigación, es que los comerciantes informales conozcan las leyes tributarias para formalizarse y que la comunidad en general tome 
conciencia que la evasión tributaria es perjudicial para todos y que se debe comprar sólo al comerciante formal ya que esto beneficiará al Perú.

\subsection{Objetivo Principal}

Evidencia la evasión de impuestos generada por la informalidad comercial ambulatoria en los alrededores del mercado San Francisco ubicado en el distrito de Villa María del Triunfo.

\subsection{Objetivo Secundario}

Señalar el desconocimiento de las leyes tributarias que ocasionan la evasión de impuestos generada por la informalidad comercial ambulatoria en los alrededores del mercado San Francisco ubicado en el distrito de Villa María del Triunfo.

Mostrar la falta de desarrollo de infraestructura pública por la evasión de impuestos generada por la informalidad comercial ambulatoria en los alrededores del mercado San Francisco ubicado en el distrito de Villa María del Triunfo. 


\section{CAPÍTULO III}

\subsection{El comercio}

\subsubsection{Historia del comercio}

La palabra comercio proviene del concepto latino commercium y se refiere al intercambio que se lleva a cabo con el fin de comprar o vender un producto o también se conoce como comercio a la negociación de compra, venta o permuta. Es decir, el comercio es una actividad social y económica en la cual se adquiere un bien y se paga por ese bien. La forma de intercambio en el comercio es generalmente con dinero.

El origen del comercio en la antigüedad se remonta a finales del Neolítico, cuando descubrieron que era la agricultura. Es así que cuando ellos entendieron más como era la agricultura y obtuvieron cada vez mejores cosechas vieron la necesidad de hacer intercambios con otros productos. Esta manera de intercambiar un producto por otro se le llama trueque. El trueque era la forma en que las civilizaciones antiguas comenzaron a comerciar, hasta que los antiguos romanos empezaron a acuñar monedas las cuales eran hechas de oro o plata. El uso del dinero fue un gran avance para la economía, ya que no era necesario que las dos partes que hicieran una transacción tuvieran una mercancía para intercambiar.

En la edad media, surgieron rutas comerciales transcontinentales que intentaban satisfacer la gran demanda de bienes y mercancías en Europa. Alrededor del año 1400, Europa busca nuevas rutas comerciales hacia la India para comercializar sus especias, siendo ganador de ese monopolio Portugal y España, asimismo, el Descubrimiento de América, fue un gran paso en el comercio para los europeos. Antes del siglo XIX, las travesías transatlánticas se hacían con barcos a vela las cuales eran muy lentas y peligrosas, luego con los barcos a vapor estos viajes fueron más rápidos y seguros. Con la revolución industrial, hubo varios cambios en el transporte como el del ferrocarril, los cuales reavivaron el comercio. $Y$ 
finalmente los automóviles y las carreteras los cuales provocaron que las mercancías se puedan transportar al lugar exacto de su consumo. (Paredes, 2016)

En la época de los Incas se sabía que era importante el intercambio de productos para el desarrollo y esto hizo que el comercio creciera a lo largo del imperio incaico y de Sudamérica. El Perú por su ubicación se convirtió en el centro del comercio, en ese tiempo se utilizó el trueque. Con la conquista española hubo un intercambio comercial con Europa, los metales preciosos extraídos de las colonias americanas se convirtieron en la base del expansionismo de España y la consolidación de las economías europeas (Paredes, 2016), en 1568, se acuñaron las primeras monedas en el Perú según el Museo Numismático del Perú. Hubo otras actividades económicas en esta época como la agricultura y la ganadería, se exportó caña de azúcar. Asimismo existían industrias artesanales, como los obrajes, las cuales proporcionaban telas y frazadas para la población y los ejércitos.

Desde 1809 el Virreinato, estuvo en guerra contra los movimientos emancipadores que surgieron en el continente, estos costos de la Guerra de Independencia fueron altos y fueron financiados por la subida de impuestos que desalentaron el consumo. Luego del fin de la dominación española el Perú quedó en depresión la cual duraría más de 25 años (Zeolla, Adelardi, Caprarulo, 2014).

En el gobierno de Ramón Castilla, la producción de guano y salitre se convirtieron en los principales productos de exportación, durante este tiempo los ingresos fiscales del estado peruano estuvo supeditado casi completamente a la exportación del guano. La guerra con Chile desde 1879 a 1883, dejó en crisis la economía del Perú., con el agotamiento del guano de las islas y el salitre, aparece la exportación de cobre y petróleo. Durante los gobiernos posteriores la economía se basó en la exportación de recursos naturales y la penetración intensa de capital internacional.

En la década de los ochenta, la economía en el Perú estuvo muy afectada ya que se enfrentó a muchos problemas, como el fenómeno del niño y el terrorismo (Zeolla, et al. 2014). Desde el año 2000 hasta el presente, la economía peruana ha tenido un gran crecimiento debido a la alta exportación de materias primas. Sin embargo, a pesar de tener un crecimiento económico, la informalidad se ha reducido escasamente, entre 2006 y 2016 el empleo informal pasó de 79\% a 73\%. Al parecer 
la informalidad sería la única salida que tienen los pobres para salir de la pobreza (Inchauste, 2012)

\subsubsection{Comercio Formal}

El comercio formal es aquel que funciona bajo las leyes de comercio del país en donde se realiza y se ampara en los estatutos legales vigentes. El comercio formal necesita de normas más claras y más justas para desarrollar su trabajo. La economía formal está compuesta de empresas y trabajadores que actúan dentro de la legalidad. En la formalidad la propiedad está registrada, las empresas cumplen con los requisitos legales y sus trabajadores se encuentran en las planillas. Según las leyes y las normas vigentes, todos ellos deben pagar impuestos y contribuir al financiamiento del Estado. Los elementos de esta economía, pertenecen al sistema y pueden ser fácilmente supervisados. El sector formal está conformada por grandes corporaciones nacionales y extranjeras que generalmente son privadas (Durand, 2007).

Sin embargo según Durand, 2007 "Que estén dentro del sistema no quiere decir, particularmente para los que tienen poder, que no puedan abusarlo o aprovecharlo. La formalidad da poder y, por lo tanto, privilegio, pero sobre todo para aquellos que lo concentran, las élites económicas y los políticos de turno".

\subsubsection{Comercio informal}

La palabra informalidad se define como una falta de respeto a las normas así también como una falta de seriedad o protocolo. La informalidad comercial es un tipo de transacción no estructurada y que no se rigen por las leyes o normas que regulen sus actividades. El término informalidad se le asigna al antropólogo económico británico Keith Hart, quien lo mostró en 1971 durante la conferencia "Urban Employ in África "en la universidad de Sussex, Inglaterra. El observó en base a sus investigaciones realizadas en Ghana que el sector informal no solo permanecía sino que se había incrementado. La OIT examinó sistemáticamente esas ocupaciones notando que no se las identificaba, registraba, protegía ni regulaba, y este sector no solo incluía trabajos marginales para sobrevivir sino empresas rentables (OIT, 1972). Partiendo desde entonces, este concepto adolecía durante bastante tiempo no solamente de un marco teórico que explicara su carácter estructural, sino también de una falta de acuerdo con respecto a su definición. 
La informalidad comprende el conjunto de ocupaciones económicas autogeneradas por la población, principalmente en zonas urbanas, en gran parte migrantes de las zonas rurales, denominadas informales. Por no adaptarse a los modelos de empresa y empleo que se conocían con anterioridad, y se expresan en la proliferación de vendedores ambulantes en las calles de las principales ciudades y mercados de barrios populares

La informalidad a nivel internacional, el trabajo informal en el mundo es un fenómeno muy desarrollado, con un $60 \%$ de la fuerza laboral comprometida con una proyección ascendente, así que para el 2020 representará el 66\%, según la Organización para la Cooperación y el Desarrollo Económico. Más de 900 millones de trabajadores se pueden considerar informales ya que no cuentan con Seguridad Social y si hablamos del sector agrícola la cifra se eleva a cerca de 2.000 millones, según el informe de la OCDE. También se precisó en este informe que 700 millones de aquellos trabajadores viven en la pobreza extrema y 1200 millones tienen ingresos inferiores a dos dólares diarios.

Jamele Rigolini, gerente sectorial de Desarrollo Humano para los países andinos del Banco Mundial y uno de los autores del reporte "El emprendimiento en América Latina: muchas empresas y poca innovación", afirma que es un síntoma de desequilibrio que existan tantas microempresas con poco potencial de crecimiento y que no generan empleo de calidad. Uno de cada tres emprendedores no contrata empleados y pueden pasar décadas sin crecer.

El ser informal es una elección donde los agentes evalúan los costos y beneficios de ser parcial o completamente informal (Loayza, 1997), observó que el PBI llegó a un 57,4\% en los años del 1990-1993

La informalidad en el Perú, es una particularidad elemental del subdesarrollo y se manifiesta cuando los costos de adaptarse al marco legal y normativo de un país son más que los beneficios que se conseguiría, el cual debe comprenderse como un fenómeno complejo y multifacético. En el Perú se han hecho muchos estudios sobre la economía informal, estos estudios hablan sobre la economía informal en el Perú mostrando que las actividades extralegales y actividades económicas de subsistencias al margen de la ley, la principal causa de su informalidad son los costos de la legalidad el cual se encuentra un enfoque 
monetario el cual es una demanda de dinero que no se explica por transacciones bancarias (De Soto, 1986).

El comercio informal en el Perú, se remonta a 1535 en la recién fundada Ciudad de los Reyes, en ese entonces los que se dedicaban a este trabajo eran los mismos españoles y criollos de pocos recursos económicos. Pese a que no hay documentos exactos, que digan el número de comerciantes que iniciaron el comercio ambulatorio, se sabe que esta actividad tenía un rol muy importante en esa época. Lima se convirtió en el centro de esta actividad ya que muchos mercaderes se vieron beneficiados con las guerras civiles. Tiempo después se incorporaron a este negocio ambulatorio los mestizos, negros y mulatos y a mediados del siglo XVII los indios (Iwasaki, 1989).

En relación a los primeros indicios de comercio ambulatorio, Iwasaki Fernando (1989) que: "Conforme aumentaba el dinamismo urbano, iban definiéndose los personajes: junto al encomendero rico veremos al soldado sin fortuna; el empedernido aventurero contrastará con los curiosos transeúntes y marineros de paso, y los artesanos reconocidos por el cabildo destacarán sobre los artesanos indios o negros que jamás contaron con taller propio por las diferencias de castas. Por eso al lado de los grandes comerciantes que representaban a una firma sevillana, o junto a los mercaderes profesionales con tienda abierta en las calles principales, fueron apareciendo los cajoneros y mercachifles, últimos exponentes de la jerarquía mercantil”. Estos ambulantes eran llamados buhoneros, mercachifles, regatones y también cajoneros por las tienditas de cajones las cuales estaban en toda la calle. Los cabildos eran los municipios de la época colonial., este organismo fue traído por los españoles en la conquista. En las actas de los Cabildos de 1535 a 1539 se pueden encontrar las primeras multas, sanciones y castigos a los comerciantes ambulantes que vendían pan y carne asimismo las primeras reubicaciones de los ambulantes ya que ellos se instalaban en los portales de la plaza de armas (Iwasaki, 1989).

Esta actividad a inicios de la república, en 1915, ya era reglamentada estableciéndose un cobro por el uso del lugar lo cual significó un avance para reclamar el derecho de uso de la vía pública para el comercio (De Soto, 1987). 
Al correr del tiempo, las cosas fueron cambiando, a partir de los años ochenta el comercio ambulatorio creció debido a las pocas oportunidades, el desempleo, el querer ser independientes, fueron los comerciantes de provincia que se adueñaron de este negocio informal. Esto se debió a los migrantes de zonas rurales que se trasladaron a Lima la cual acogió a miles de ambulantes que ocupaban calles enteras para su comercio informal, ante la mirada desinteresada de las autoridades locales de ese tiempo (Vich,2001)

En el comercio informal llamado comúnmente comercio ambulatorio, la gente comenzaba a ocupar la vía pública, la cual es de todos y la utilizaba para sus operaciones comerciales sin contar con licencia, sin dar facturas y sin pagar ningún impuesto, pero en algunos casos estaba favorecida por un régimen de excepción legal, pagando un derecho llamado "sisa" que le hizo disfrutar de una tolerancia municipal (De Soto, 1989). El dinero recibido por concepto de sisa, no es para nada insignificante para las municipalidades y significa como el Instituto Libertad y Democracia, calcula una de sus principales rentas (De Soto, 1989)

Los ambulantes durante años eran la cara de la ciudad, con su bullicio, y empeño pero también eran un desorden suciedad y caos en las calles, aumentando el tráfico de peatones y de vehículos. De esta manera, en la ciudad, en distintas zonas fueron desarrollándose centros de comercio informal creciendo cada vez más el número de ambulantes es así como surgió el ahora Mercado Central y el que fue el Mercado La Parada. Así también creció el emporio comercial de Gamarra. Algunos de estos centros informales ya no existen y otros están en un proceso de reordenamiento pero todos forman parte de la historia de Lima la capital del Perú.

En la alcaldía de Luis Bedoya fue tal vez en donde el comercio ambulatorio tomó mayores dimensiones y se generó un gran caos en calles tan conocidas como el Jirón de la Unión, Avenida Tacna, Plaza San Martín, Avenida Abancay, Parque Universitario entre otras. Bedoya levantó el actual Mercado Central, que en sus inicios funcionaba como mercado mayorista, renovó toda la zona y le dio el rasgo comercial que hasta hoy continúa (La República, 2010)

El Alcalde que le dio guerra a los ambulantes fue Alberto Andrade, él encontró la ciudad en medio del caos, después de una dura batalla logró sacar a los ambulantes de los jirones Lampa, Puno, Apurímac, Bambas y Cusco, además del 
Mercado Central, Mesa Redonda, Tacora, la avenida Abancay, entre otros (Perú 21, 2015)

Después de mucho tiempo la ciudad fue mejorando poco a poco con menos caos en las calles, el comercio ambulatorio se fue ordenando así como el tráfico en las pistas. Pero en la actualidad, las cosas no han cambiado mucho porque al menor descuido de las autoridades, los ambulantes se apoderan de las calles, todavía hasta hoy se sigue atacando el desorden. Actualmente, se han hecho varios estudios intentando medir el sector informal los cuales generan gran confusión y desacuerdos importantes. En este entorno, los variados aportes teóricos que se han dado respecto de la informalidad, pueden abreviarse principalmente en tres enfoques: el estructuralista, el liberal y el contemporáneo:

\section{a. Teoría Estructuralista}

De acuerdo al INEI (2014), en un estudio denominado "Producción y Empleo Informal en el Perú", nos menciona que para la corriente estructuralista, la informalidad es el resultado de la falta de capacidad del sector moderno de la economía capitalista para aprovechar la gran cantidad de mano de obra generada en el mercado de trabajo. De esta manera, una gran masa de mano de obra desempleada tiene como único recurso la autogeneración de empleos de subsistencia de baja productividad.

En ese sentido Carboneto, Hoyle y Tueros (1988), señalan lo siguiente: La cantidad de trabajadores descartada de los empleos de alta productividad e inversión por hombre del sector actual solo en parte, continua como integrada por desempleos abiertos. Para subsistir, estos idean puestos sin tener un adecuado capital, ni tecnología suficiente.

\section{b. Teoría liberal}

Tenemos como el mayor exponente de esta teoría a Hernando de Soto, 1986, quien dice al respecto que "el enfoque liberal no admite otra clase de segmentación que la originada por las barreras institucionales que impiden el funcionamiento de los mecanismos del mercado".

En conclusión, la escuela liberal indica que la informalidad es resultado de los obstáculos burocráticos, porque estas no permiten el habitual funcionamiento de los mecanismos de mercado. Siendo la informalidad, la forzosa consecuencia popular a 
estos endurecidos estados mercantilistas, que permanecen concediendo el derecho de intervenir legalmente en la economía a un elegido grupo.

\section{c. Teoría contemporánea}

En esta teoría, el término informal comprende "las acciones de los agentes económicos que no se adhieren a las normas institucionales establecidas o a los que se niega su protección”. (Fiege 1990).

Por otra parte Castells y Portes (1989), afirman que "todas las actividades generadoras de ingresos, no reguladas por el Estado en entornos sociales, si se encuentran reguladas en otras actividades similares".

José Matos Mar (1985), expresa que la informalidad se caracteriza por la "falta de presencia del Estado".

Hernando de Soto (1986), en su obra "El otro Sendero", expreso que el inicio de la informalidad se debería a una excesiva participación del estado en la sociedad civil y en la actividad económica; en otras palabras, brota como una respuesta frente a la ineficiencia y distorsiones introducidas por el estado dentro de un proceso histórico de una economía mercantilista. De esto se deduce, que lo costos de transacción y legalización resultaban inaccesible para los informales, quienes prefirieron no respetar las leyes, logrando establecerse como una opción de sobrevivencia a través de propia iniciativa económica.

Sumado a esto, es necesario indicar que es Hernando De Soto quien define dos conceptos fundamentales para el análisis, como son los costos de la formalidad y los costos de la informalidad.

Como costos de la formalidad tenemos:

a) Los costos para acceder al sector formal, entregado por la constitución de la personería jurídica, los costos notariales de registro, las licencias y el tiempo tomado en dichos trámites.

b) Los costos de permanencia, en el cual se consideran tres grandes categorías que son: impuestos, regulaciones laborales y ambientales requerimientos burocráticos, papeleo.

De igual modo los costos de la informalidad son: 
a) Las multas que dan al informal cuando su situación es descubierta por las autoridades expertos, estas pueden ser tasas que da el propio Estado o tal vez sobornos entregados a fiscalizadores corruptos.

b) El impedimento de lograr disfrutar completamente las ventajas de los servicios públicos entregados por el Gobierno.

\section{A. Causas del Comercio Informal}

La economía informal en el Perú se origina por muchas razones, una de estas razones es la migración andina a la capital la cual hizo colapsar a los sistemas urbanos y fue produciendo lo que conocemos hoy como mercado informal. (De Soto, 1989)

Otra motivo para la existencia de un sector informal son los elevados costos de la formalidad, tanto para el acceso como para la permanencia. Para establecer su propio negocio una persona necesita contratar los servicios de un abogado y luego esperar semanas o meses en obtener permisos y licencias en un sin fin de oficinas públicas diferentes, asimismo encontrarse con funcionarios corruptos que piden un pago para agilizar los trámites (De Soto, 1989)

Las causas de la informalidad son:

- Falta de buena gobernanza

- Déficit de trabajo decente

- Alta participación de sector primario en estructura productiva

- Elevado costo para cumplir con el marco legal y normativo

- Altas barreras de entrada al sector formal

- Problemas estructurales sociales y culturales

- Déficit de infraestructura y de buenos servicios públicos

- Escasa censura social del fenómeno

(OIT, 2014)

\section{B. Comercio ambulatorio}

Según el Censo de vendedores ambulantes de 1976, ejecutadas por las autoridades a nivel gubernamental, definieron el término comercio ambulatorio como: “. . . actividad económica consistente en la venta, al por menor, de productos nuevos y/o usados o la prestación remunerada de servicios en la vía pública o en el 
interior de mercados y otros lugares de acceso público, sin poseer un establecimiento, kiosco o puesto con características de permanencia"

El comercio ambulatorio de Lima tiene un rol importante en la economía urbana ya que entrega a la clase trabajadora los bienes y servicios que ellos requieren pudiendo ser estos de dudosa calidad. Ser ambulante es una alternativa laboral de emergencia para los que no tienen trabajo, principalmente en el Perú donde no existe un seguro para los desempleados (Osterling, 1981)

Los ambulantes, se inician vendiendo sus productos en ciertas zonas urbano-marginales, luego se instalan como mercados informales o "zonas liberadas", y luego de pasar por un tiempo de conflictos o negociaciones con la municipalidad, acaban estableciéndose en un mercado estable y el gobierno municipal nuevamente tiene el control de la zona recuperada. Este control es la mayoría de las veces por un tiempo, porque hay muchos gobiernos débiles, corruptos y lamentablemente otro grupo de informales vuelve a empezar (Durand, 2007)

\section{Clases de Comercio Ambulatorio}

Según, (De Soto, 1989) tenemos las siguientes clases de Comercio Ambulatorio:

\section{Itinerante}

En esta clase están los vendedores ambulantes que caminan o recorren las calles ofreciendo su mercancía a eventuales clientes que encuentran a su paso. No se encuentran en un lugar fijo, trabajan solos y con poco capital. Este ambulante a medida que va adquiriendo experiencia, va trazándose un itinerario para su recorrido por las calles en búsqueda de clientes. Este recorrido le permite observar cual es el mejor lugar para establecerse, ya que en un lugar fijo los clientes podrán encontrarlo fácilmente.

\section{De un lugar fijo en la vía pública}

Son vendedores que han dejado de caminar por las calles, han ubicado un lugar en la vía pública porque lo han visto conveniente para sus fines posiblemente porque hay un potencial número de clientes que transitan por ese lugar. Estos comerciantes a determinada hora del día se instalan con sus productos para venderlos. Generalmente estos comerciantes no es que no paguen nada por ocupar 
un lugar en la calle, ellos pagan un derecho de piso a los municipales que controlan los espacios de venta en las calles.

\section{De los Mercados informales}

Son mercados construidos informalmente para ambulantes que ya no quieren trabajar en las calles. La finalidad de estos comerciantes es dejar las calles porque allí tienen una serie de limitaciones. La calle, no ofrece seguridad para hacer una inversión a largo plazo

\subsubsection{Los ambulantes como problema social}

El Sociólogo (Gamarra, 2014) dijo que "La problemática de los ambulantes es muy compleja, pues encierra una dimensión social, económica, legal e incluso política, por lo cual amerita un abordaje integral que hasta el momento no se ha dado por parte de nuestras autoridades locales, que simplemente se limitan a organizar desalojos pero sin la planificación adecuada que garantice resultados efectivos y a largo plazo"

A bastantes personas les molesta caminar por la calle y encontrarse con cientos de vendedores ambulantes que invaden y se apropian de las calles, pero también hay algo que sobrecoge a muchos, es ver a los policías, serenazgo o a los fiscalizadores perseguir y arrebatarles su mercadería a los comerciantes ambulantes como si fueran verdaderos criminales, y solo son personas atemorizadas por la persecución y tratando desesperadamente que no le decomisen lo que tanto trabajo les costó obtener, $Y$ es que con respecto a los vendedores ambulantes muchos ven un problema, pero otros ven simplemente un drama social.

El Sr Adrián, vendedor formal nos contó su historia:"Por la necesidad de trabajo, por falta de trabajo se vuelve independiente, en mi caso comenzó como comercio ambulatorio en los tiempos de los 80's iniciamos vendiendo en la calle vendiendo tubérculos, verduras, comenzamos de a poco con un capital de 100 soles". Hay muchos vendedores ambulantes que son el sostén de su familia y han visto la manera de trabajar en las calles como su único medio de obtención de dinero. La Sra. Delia, ambulante nos contó cómo comenzó a trabajar de esta manera " en el principio mi esposo era fabricante de mercadería y allí comenzó, de niña cuando estudiaba vendía en el colegio también para poder estudiar, vendía flores, empanadas, todo eso y de allí me gusto el negocio, luego de eso tomé una 
clase empresarial y allí con todos los consejos me dieron, comencé a seguir adelante con esos métodos que me dieron, comencé a aplicarlo" y ante la pregunta de porque no se formaliza "Bueno por el momento no, porque tengo a mi hija que está estudiando en la universidad y tengo gastos con ellos, pero de acá al otro año que mi hija ya acabe, allí si voy a tener mi propio local y voy a comenzar a trabajar allí."

Para el Señor Pedro Vílchez Representante de la Gerencia de Desarrollo Local de la Municipalidad de Villa María del Triunfo "Porque es un medio de trabajo rápido y fácil, mucha gente agarra sus productos o lo que tiene a la mano y sale y lo vende a la esquina de su casa, ese proceso de formalización es un trabajo que nos compete a nosotros, darle la capacitación, darle la orientación, darle las recomendaciones, mucha gente sale y por la misma necesidad empieza a vender lo que se le ocurre de alguna manera improvisada", "Bueno hay muchas razones, una de ellas es la falta de recursos no, su propio modo de vida, de hacer las cosas, digamos como empíricamente y también la falta de decisión a veces de las autoridades que no toman las riendas para poder encontrar este problema que tienen algunos distritos" y " está complicado en el distrito de villa María, 7000 ambulantes es bastante, imagínese quitar el puesto de trabajo a 7000 personas. ahorita, un dolor de cabeza, así que es un trabajo que se tiene que hacer con mucho cuidado".

Este en un problema social que no se va acabar de la noche a la mañana, y los gobernantes de turno tienen la última palabra para buscar una solución que se va a ir dando poco a poco.

\subsubsection{Comercio ambulatorio principales zonas informales en Lima}

Los distritos de Lima Metropolitana con zonas de mayor concentración de venta ambulatoria son:
a. Cercado
b. La victoria
c. Comas
d. San Juan de Lurigancho
e. San Martin de Porres 
f. Ate

g. Surquillo

h. Rimac

(FAO, 2003)

En Lima Metropolitana existen más de 300,000 ambulantes, de cada 4 personas que se dedican a la venta ambulatoria, 3 son mujeres y 1 es hombre. Las edades de más del 50 \% de ambulantes fluctúan entre 25 y 44 años (INEI, 2013).

\subsection{Distrito de Villa María del Triunfo}

\subsubsection{Historia y antecedentes}

Villa María del Triunfo en el periodo prehispánico, era un gran ecosistema conocido como Loma por tener condiciones ecológicas especiales. Antes que se creara el distrito, dos grupos humanos habían formado: Tablada de Lurín y Villa Poeta José Gálvez Barrenechea en lo que es hoy parte de Villa María del Triunfo. Luego, la Sociedad de Obreros del Sagrado Corazón de Jesús de Surquillo, cuyos integrantes se encontraban en una situación de vida lamentable, fundaron la Sociedad El Triunfo de la Restauración, dirigida a encontrar terrenos para la construcción de viviendas(munivmt.gob.pe)

El distrito de Villa María del Triunfo es uno de los 43 distritos que forman la provincia de Lima y es uno de los más grandes y poblados. Se encuentra localizado en el departamento de Lima, fue fundado el 28 de diciembre de 1961 y creado por la Ley $N^{\circ} 13796$. El distrito es Villa María del Triunfo, limita al norte con el distrito de San Juan de Miraflores; al este, con el distrito de La Molina; al sur, con los distritos de Pachacámac y Lurín; y al oeste, con el distrito de Villa El

Salvador(munivmt.gob.pe)

Villa María del Triunfo tiene una altura de 158 m.s.n.m. unos 70,57 km2 de extensión, 461,200 habitantes y 120,551 hogares (INEI, 2017)

El Distrito de Villa María del Triunfo está conformada por 7 zonas:

a. Nuevo Milenio

b. Villa Poeta Jose Galvez

c. Villa María del Triunfo (Cercado)

d. San Francisco de la Tablada de Lurín

e. Nueva Esperanza 
f. Jose Carlos Mariategui

g. Inca Pachacutec

(munivmt.gob.pe)

\subsubsection{Los ambulantes en el distrito de Villa María del Triunfo}

El Sr Pedro Vílchez de la Municipalidad nos dijo "aproximadamente debemos tener 7000 ambulantes" y ante la pregunta de cuántos son formales nos dijo "aún no lo sabemos eso, estamos recién recopilando la información, lo tenemos todo en archivos tendremos menos de 60 días en esta gestión, y estamos comenzando a armar nuevamente todo"

$Y$ con respecto a las medidas que está tomando la Municipalidad con respecto a los ambulantes el Sr. Pedro Vílchez nos dijo: "Estamos trabajando ahorita, en la elaboración de un proyecto de ordenanza que pretende ordenar y formalizar todo el comercio ambulatorio en todo Villa María del Triunfo, tenemos una ordenanza del 2008 que ya está desfasada, podríamos decirlo y no cumple con las expectativas que tiene la ciudad, la ciudad a crecido demasiado y a crecido de una forma desordenada y ahorita estamos justo trabajando en un proyecto de ordenanza para poder encauzar y establecer unas zonas rígidas, algunas zonas rígidas para que esto no se desarrolle de una manera desordenada".

La Municipalidad de Villa María desde el mes de enero 2019 que comenzó sus funciones está fiscalizando diferentes zonas del distrito que habían sido tomadas por ambulantes, basándose en la Ordenanza Municipal No 0492008/MVMT que los faculta para realizar este ordenamiento del comercio ambulatorio.

\subsubsection{Principales rubros del comercio informal}

\section{A. Comida}

Los rubros de comida se pueden dividir en dos, en el dia y en la noche, ya que en esta estación de verano, la gente tiende a consumir productos dependiendo de la hora.

En el dia:

a. Horno pequeño para hacer pan

b. Carretilla de pan con chorizo 
c. Carretilla de raspadilla

d. Carretilla de choclo sancochado

e. Mesa con ollas de mazamorra morada y arroz con leche

f. Baldes con chicha morada

g. Carretilla de venta de ceviche al paso

h. Carretilla de frutas

i. Cajón de paltas

j. Mesita para venta de queso fresco

k. Carretilla pequeña con cocinita para la venta de huevos de codorniz y codorniz pelado.

En la noche:

a. Carretilla con cocinita y sartén para venta de picarones

b. Carretilla con horno pequeño para pizzas

c. Carretilla con cocina y parrilla para venta de panchos

d. Carretilla con cocina para venta de salchipapas y pollo broaster

e. Carretilla con cocina para venta de mollejita

f. Vitrina rodante con porciones de pasteles

g. Carretillas de frutas

h. Baldes de aceituna

i. Carretilla de choclo sancochado

j. Carrito para venta de helado

B. Ropa y zapatos

a. Tabla con bancas para venta de Blusas y pantalones para mujer

b. Tabla con cajones para venta de polos, short para hombres

c. Plástico en el piso para venta de medias y ropa interior

d. Carretilla para venta de sandalias

e. Plástico en el piso para venta de zapatillas

f. Plástico en el piso para venta de carteras

\section{Otros}

a. Puesto de telefonía, teléfono fijo, cable e internet

b. Personas ambulantes ofreciendo recargas para celular

c. Baldes y macetas para venta de flores y plantas 
d. Carretillas con televisor y dvd para venta de películas

e. Carro de supermercado para venta de perfumes, maquillajes y joyas de fantasía

f. Plástico en el piso para venta de repuestos de cocina de gas, incienso y otros.

(Trabajo de campo, enero y febrero 2019)

\subsubsection{Problemas que afrontan los comerciantes informales}

\section{A. Confiscación y pérdidas materiales}

En algunas Municipalidades, los agentes fiscalizadores y serenazgo, actúan de una manera violenta al desalojar a los vendedores ambulantes lo cual es bastante criticable ya que utilizan la violencia física para tal propósito. También se cuestiona bastante lo que se refiere a la confiscación de sus bienes, que cuando los agentes municipales arrebatan los bienes a los referidos comerciantes, están incurriendo en apropiación ilícita o robo, ya que la Ley Orgánica de Municipalidades permite confiscar pero cuando se trata de productos en descomposición o que se encuentren en situación insalubre. No se le puede quitar los bienes y menos golpear a los ambulantes ya que tienen sus derechos como seres humanos, y si llegara a pasar, se puede denunciar a los fiscalizadores, serenos y jefes del área (Agencia Andina, 2015)

Según el Especialista Castaglioni "Debe acabar esta mala práctica, porque se estaría usando recursos que pagamos todos por concepto de arbitrios, para perseguir ambulantes y encima maltratarlos", (Correo, Nov 2015)

En algunos casos, como por ejemplo en el distrito de Chorrillos, los mismos agentes de serenazgo, han sido descubiertos cobrando cupos a los vendedores ambulantes. Los comerciantes denunciaron que les cobraban entre 5 y 10 soles diarios por dejarlos trabajar y para tal fin utilizaban una camioneta de la municipalidad y si los comerciantes se negaban a pagar el cupo les quitaban su mercadería.(Peru 21, mayo 2017)

El Sr Pedro Vílchez de la Municipalidad con respecto a la fiscalización nos dijo "Io que pasa no es que nos lo llevemos, eso se retiene provisionalmente no, eso está establecido en las ordenanzas, si el ambulante no cumple con lo que dice la ordenanza, la municipalidad tiene que venir y en modo de custodia retener el 
producto mientras se pague la multa o se ordene no, esto generalmente sucede en los comerciantes ambulantes que no están debidamente registrados, los que están registrados o están trabajando en una zona autorizada no tienen ese problema"

En las gestiones anteriores del distrito de Villa María del Triunfo, los ambulantes pagaban el "sisa" de 1.00 sol diario a la municipalidad, era un pago para poder trabajar en la calle. Según el Sr Pedro Vílchez de la Municipalidad, este pago del "sisa" ya no se está dando "no, actualmente no, estamos justo haciendo la evaluación de todo eso, el sisa se cobraba 1 sol diario"

En los alrededores del Mercado San Francisco del distrito de Villa María del Triunfo, los vendedores ambulantes piden un permiso anual según los rubros permitidos a la Municipalidad para poder trabajar en un lugar específico de la vía pública.

Los vendedores ambulantes que no hacen ese pago están expuestos a ser sacados del lugar por los fiscalizadores y en el peor de los casos a la confiscación de su mercadería que como ya lo vimos líneas arriba está prohibido. Generalmente los ambulantes que no hacen ese pago, trabajan en la noche porque a esa hora saben que los trabajadores municipales no están laborando. Si es que los comerciantes ambulantes están trabajando en el día, cada vez que aparece un municipal huyen del lugar (trabajo de campo Enero y Febrero 2019)

\section{B. Incremento de la delincuencia}

Los vendedores ambulantes al estar trabajando en las calles están expuestos al robo de sus mercaderías, ya sea por delincuentes comunes o por pandillas de la zona. Al ser informales no tienen ninguna protección, ningún derecho.

\section{Riesgos ocupacionales de los comerciantes informales}

El ambiente en el que laboran los vendedores informales es inadecuado, lo cual sumado a extensas jornadas laborales, supone riesgos para su salud ya que sufren generalmente de dolor de espalda, dolor de piernas, dolor de cabeza, ardor o irritación de los ojos, pérdida de la audición, cansancio visual y cansancio físico.

Los comerciantes informales se dedican a la venta de cualquier producto estando expuestos a condiciones riesgosas, que se relacionan con el levantamiento de cargas pesadas, posturas inadecuadas, trabajo repetitivo y organización inadecuada del trabajo. 
El sector informal reúne a una población vulnerable las jornadas son largas y extenuantes, y en general las precarias condiciones de trabajo afectan las condiciones de vida y salud ya que se encuentran expuestos al ruido de los vehículos y a la polución y por lo tanto a un envenenamiento por plomo y problemas respiratorios por el humo de los carros, adoptan posturas inadecuadas a la hora de vender sus productos produciendo trastornos músculo esqueléticos asociados con la postura estática y otros riesgos ergonómicos, también tienen un alto riesgo de contraer enfermedades transmitidas por parásitos, trabajan de 6 a 7 días de la semana, aproximadamente 10 horas por día y mayormente no tienen seguridad social (Revista Salud Pública, 2012)

Las condiciones de trabajo son muy importantes para las personas, porque se pueden relacionar con el estado de salud. Un equilibrio en las dimensiones del ser humano solo se puede lograr si hay condiciones óptimas en el trabajo y condiciones razonables de salud que le permitan un desarrollo confortable y mejor calidad de vida.

\subsubsection{Rol de la sociedad ante esta problemática}

El pueblo va en forma habitual a este sector de la economía informal, ya sea porque está más próximo o porque encuentra los productos más económicos. Pero se olvida que los informales carecen de una reglamentación, ocupan espacios públicos, lo ensucian, perjudican a terceros propician en algunos casos los actos delictivos, la estafa, no pagan impuestos, perjudican a los vendedores formales al estar afuera de sus negocios, etc. El pueblo es un actor en esta problemática y como tal debe tomar acciones con responsabilidad y no quedarse de espectador solamente (Trabajo de campo, Enero y febrero del 2019)

La Sra Kreysy dueña de un puesto de pollos dentro del mercado San Francisco dijo " yo pienso que ellos deben formalizar para un inicio yo creo que puede estar permitido porque no saben pero ya ellos a veces están demasiado años en la calle, 15 a 20 años?, porque están afuera, porque realmente no tienen dinero?, eso no es la verdad, realmente ellos han hecho más dinero, por eso no se formalizan, no les conviene, están acostumbrados"

El Sr Pedro Vílchez de la Municipalidad nos dijo "Cómo afecta, nos genera desorden, nos genera residuos sólidos, incrementa la basura y la municipalidad deja 
de percibir ingresos por parte de ellos, lo que la municipalidad trata de promover, para mejorar esto, es que estos comerciantes en un pequeño a corto plazo puedan volverse formales y luego a lo largo tener un negocio propio en un establecimiento con las licencias de funcionamiento con certificado de fuerza civil y que ya no estén en la vía pública" "generalmente lo que se recomienda es ir o solicitar un servicio de manera formal, siempre preferimos que vaya a un mercado, que vayan a las tiendas, pero lamentablemente el comercio ambulatorio, digamos que es la solución al problema diario de la misma población, que sugeriría, que evitemos consumir tanto comercio ambulatorio, que consumamos más, comercio formal"

\subsubsection{Rol de sector privado}

Según la (OIT, 2014), el Sector Privado debe:

a. Cumplir con el reglamento vigente y exigirlo a sus proveedores

b. Realizar iniciativas precisas para confirmar la existencia de un ambiente adecuado para el desarrollo de empresas sostenibles

c. Auspiciar sondeos para saber la realidad del sector informal

d. Fomentar programas de RSE dirigidos a disminuir la informalidad

e. Fomentar la entrada a la educación formal y a la formación profesional

f. Delinear programas de capacitación especial para acceder a empleo

g. Fomentar la inserción financiera y el acceso a crédito

h. Patrocinar servicios de desarrollo empresarial específicos

i. Crear redes de contacto con empresas de mayor tamaño

j. Relacionar a los informales con organizaciones empresariales y ayudarlos

k. Promover una concientización de la sociedad hacia la informalidad

\subsection{Influencia de la migración en la informalidad comercial}

\subsubsection{Historia y antecedentes}

El Comercio informal está muy ligado a la Migración interna, estas se refieren al desplazamiento de la población de un lugar a otro pero dentro del mismo país, por ejemplo de una provincia a otra o hacia la capital.

Las migraciones internas en el Perú han sido muy activas desde los años cincuenta, a raíz de que las condiciones de vida de la población en algunas provincias no era la más adecuada y empeoró en tiempos de crisis, cada vez se hizo más intenso el traslado, padres e hijos, muchos dejaron sus pueblos para buscar 
mejoras económicas en otras regiones del país. Estos cambios comenzaron cuando los pobladores que vivían exclusivamente del agro comenzaron a dejar sus pueblos motivados seguramente por la reforma agraria la cual fue un proceso largo e inestable y se trasladaron a las ciudades, ocasionando que entre el periodo de 1940 a 1981 la población de la ciudad casi se quintuplicara mientras que la rural solo aumentará un tercio (De Soto, 1989).

También en las migraciones internas han tenido un rol significativo en la conformación de la sociedad actual porque han influido considerablemente en la realidad social, económica y demográfica del Perú. Es destacable señalar que los inmigrantes internos al desplazarse de un lugar a otro traen también sus costumbres, valores, folklore y gastronomía produciendo una fusión cultural en los lugares donde se instalan ya que se mezclan la costa, la sierra y la selva.

La población del interior del país llega a Lima buscando mejoras en su vida que muchas veces no encuentra, como una mejor remuneración, la ciudad no logra abastecer la demanda de los migrantes en lo que respecta a trabajo y a la parte social. Quizás los migrantes también buscaban que sus hijos accedan a una educación con niveles más altos (De Soto, 1989).

Al no encontrar empleo, los migrantes muchas veces se ven en la necesidad de buscar trabajos informales y el comercio ambulatorio es una manera de conseguir dinero rápido sin invertir demasiado.

\subsection{Estadísticas de los ingresos por trabajo informal}

En el cuadro Figura 1 que se ve a continuación, se examinan las remuneraciones agrupando las actividades en tres grandes rubros (Primario, Transformación y Servicios), se observa que en el sector "formal" las remuneraciones promedio son siempre más elevadas que en el sector informal (INEI, 2007). 


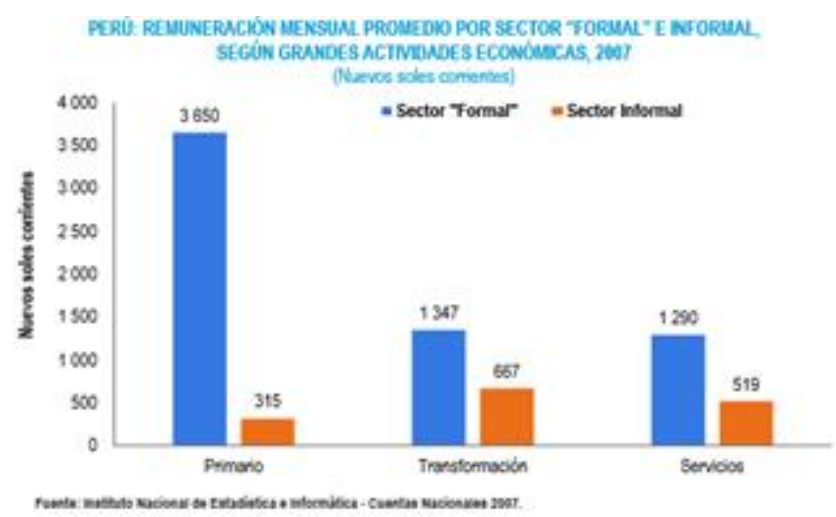

Figura 1. Remuneración mensual promedio por sector formal e informal

En el cuadro Figura 2 se observa para cada rama de actividad, la participación formal e informal en el PBI en el año 2007.

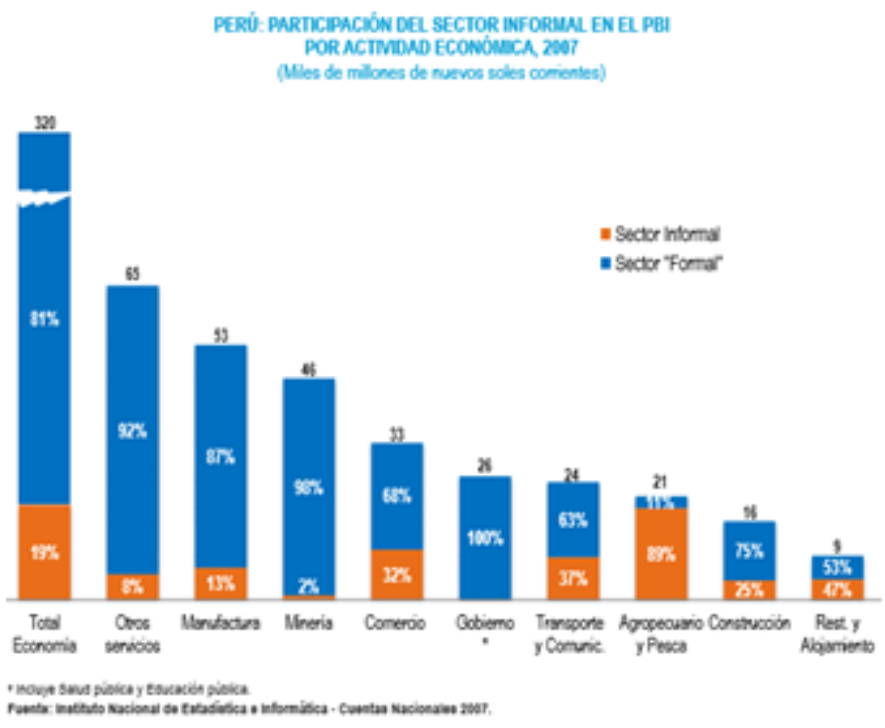

Figura 2.Participación del sector informal en el Perú

En el cuadro Figura 3 se muestra el ingreso por trabajo per cápita mensual según tipo de hogar, que resulta de dividir los ingresos del hogar entre el total de miembros. Se aprecia que los hogares con ingresos provenientes íntegramente de empleo formal tienen un mayor ingreso per cápita mensual (S/. 1 043), que los hogares mixtos (S/.569) y los hogares con ingresos provenientes del sector informal (S/. 247) (INEI, 2007) 


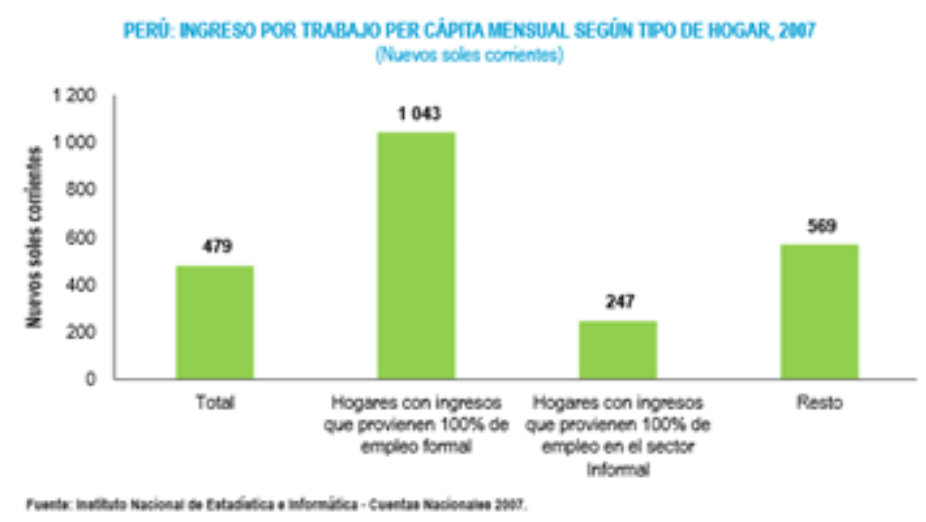

Figura 3. Perú: ingreso por trabajo per cápita mensual

Este cuadro Figura 4, muestra la distribución porcentual de las unidades productivas de la economía total, según algunas características que pueden constituir grados de informalidad. En la jerarquía propuesta, las empresas más "formales" son las jurídicas $(1,9 \%)$, mientras que las más informales son aquellas que simultáneamente no cuentan con RUC, no llevan registros contables ni tienen local $(67,1 \%)$. Esta pirámide permite distinguir que la economía peruana se compone mayoritariamente de unidades productivas informales, o que tienden a serlo dejando un escaso margen para la formalidad (INEI, 2007).

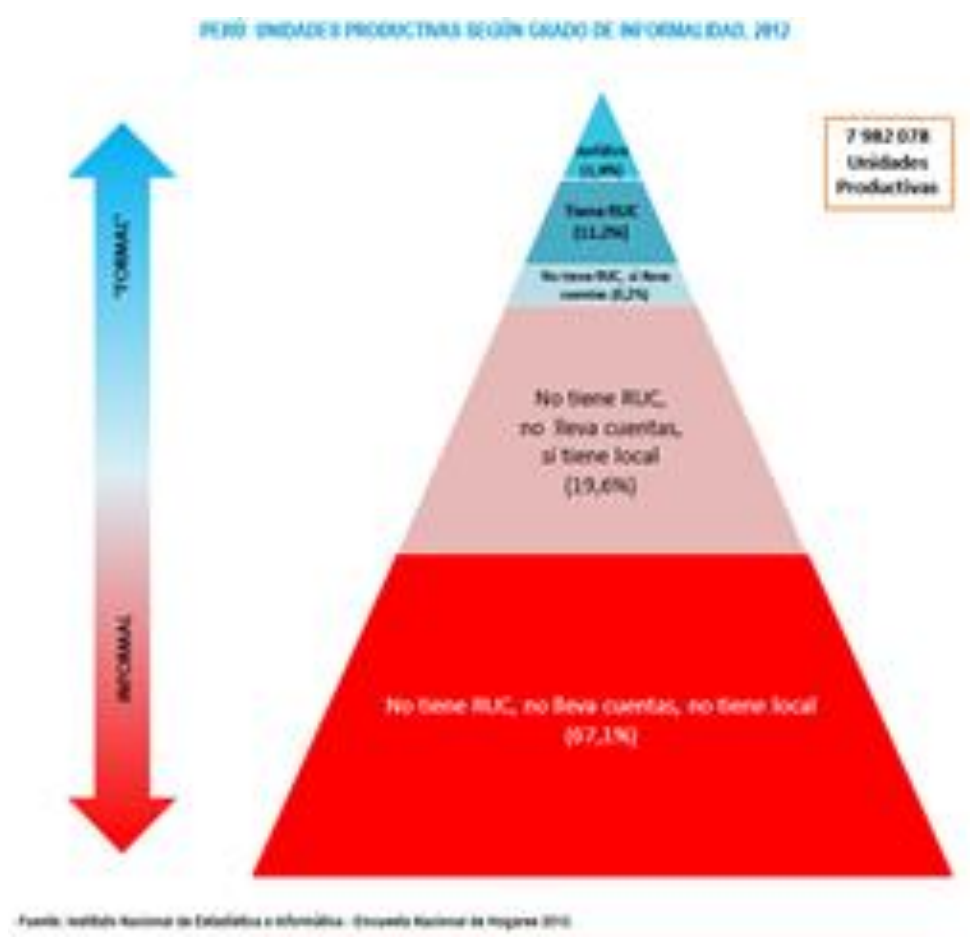

Figura 4. Unidades productivas según grafo de informalidad 


\subsection{Mercado San Francisco de Villa María del Triunfo}

\subsubsection{Historia y antecedentes}

La Cooperativa de Servicios Especiales San Francisco Ltda. fue creada el 2 de Octubre de 1964 y cuenta en la actualidad con 435 asociados.

El Sr Miguel Ángel presidente del Mercado San Francisco nos dijo que "la Cooperativa San Francisco, primero se inició como una paradita, los primeros pobladores del distrito separaron este terreno de aproximadamente 10 mil metros cuadrados para posteriormente asociarse y luego convertirlo en este gran mercado comercial, entiendo que los asociados y los fundadores se han sacrificado mucho no ha sido fácil, ha habido una época en donde esta parte estaba todo parametrado con el crecimiento provisional, querían ocuparlo y hacerlo vivienda, entonces con el apoyo de otro grupo importante del distrito de villa maría se pudo sostener. Con el asesoramiento de gente que conocía el tema del mercado, se pudieron formalizar"

El Mercado San Francisco del distrito de Villa María del Triunfo se encuentra ubicado en la Avenida Villa María 621 Cercado de VMT a 2 cuadras aproximadamente de la Municipalidad antigua de Villa María del Triunfo.

\subsubsection{Problemática de los ambulantes alrededor del mercado San}

\section{Francisco}

Los comerciantes informales ambulatorios afectan en gran medida a los comerciantes formales que se encuentran en sus puestos dentro del mercado, porque los clientes al encontrar lo que necesitan comprar en la calle ya no entran al mercado para hacer sus compras.

Según el Sr Luis vendedor formal del mercado San francisco: "Al respecto de cada gestión que ha habido de los alcaldes, 4 a 5 gestiones que han pasado, no han ejercido autoridad, las 3 avenidas alrededor, son zona rígidas las autoridades tiene que hacer cumplir las leyes del comercio ambulatorio alrededor del mercado, porque está prohibido pero hacen caso omiso porque les cobran a los ambulantes, y esto perjudica el comercio internamente, venden con un precio más bajo que nosotros los comerciantes formales, roban en el peso, productos al intemperie, no es igual que tener los productos en un local construido, mejor presencia, mejor conservación de los productos" 
La Sra Kreysy dueña formal de un puesto de venta de pollos en el mercado San Francisco nos dijo que “ ellos tienen mucha más ventaja que nosotros que estamos en un mercado formal primeramente lo que es el precio un vendedor ambulante no tiene casi gastos, solo el alquiler, y el alquiler de afuera de un espacio o puesto o pedacitos siempre sera mas comodo que pagar en un mercado, en un mercado no solo pagas el puesto, pagas luz pagas agua, pagas todo, administracion, estás sujeto a muchas reglas y tienes que cumplirlas, ellos no, por eso tienden a vender la mercadería mucho más barato entre comillas, dice la gente es mas baratos pero si tu te pones a pensar si es más barato, habrá que pesarlo indudablemente porque yo te puedo decir que te vendo 3 soles y te lo estoy vendiendo a 4 ".

El Sr Miguel Ángel Presidente del mercado dijo que " todos tienen derecho a trabajar, pero tienen derecho a trabajar formalmente, con un carnet de sanidad, debidamente uniformados, no expongan el producto de consumo al aire libre, al polvo, al humo que dañan la salud,enormemente, porque afuera la gente vende producto de 3era categoría y aparte de eso, hay quejas sobre el peso y mucha gente piensa que están vendiendo productos de calidad y al precio justo, la gente compra afuera supuestamente a un precio más cómodo"

Segun el Sr Pedro Vílchez de la Municipalidad nos dijo:"el trabajo ambulatorio afecta mucho al comerciante formal, si ustedes saben en todos los distritos hay negocios que cuentan con licencia de funcionamiento, pagan sus impuestos, pagan todos sus servicios, mientras que el comercio ambulatorio no, esto merma en ingreso al comercio formal"

\subsection{Municipalidad de Villa María del Triunfo}

\subsubsection{Leyes municipales y ordenanzas}

En primer lugar la Constitución Política del Perú del año 1993, nos dice, que toda persona tiene derechos así como el hecho de trabajar es un deber y también es un derecho.

Segun el Decreto Supremo No 005, 91-TR (26/01/91), nos dice, que el trabajador ambulante es un trabajador autónomo ambulatorio, que ha surgido debido a las circunstancias de crisis económica y desempleo. 
Y con respecto a las Municipalidades y el trabajador ambulante tenemos que, cada Municipalidad Provincial y Distrital son Gobiernos Locales, autónomos en lo político, económico y administrativo y puede regular y controlar el comercio ambulatorio , por ello se dio la Ordenanza Municipal No 049-2008/MVMT el cual dice que es objetivo de la Municipalidad de Villa María del Triunfo es el conservar y recuperar los espacios públicos ocupados por el comercio ambulatorio informal, mediante una serie de procedimientos para que el ordenamiento se haga en forma gradual.

Se da a conocer también, las zonas rígidas en donde no pueden trabajar ambulantes, salvo cumplan con una serie de requisitos y que estén dentro de los giros de trabajo permitidos.

El Sr Pedro Vílchez de la Municipalidad al respecto nos dijo " nosotros estamos poniendo en esta ordenanza como zonas rígidas, las vías metropolitanas que están bajo la jurisdicción de Lima Metropolitana, parques plazas, mercados, colegios, instituciones educativas, instituciones del estado, como puede ser, municipalidades, comisarías, juzgados, todas esas zonas, estamos declarando como zonas rígidas, alrededor de ellos no puede haber nada de comercio ambulatorio" y con respecto a las zonas que no son rígidas nos dijo "Esas van a ser las zonas reguladas, eso que le he dicho son las zonas rígidas, ahora las zonas reguladas son, que la municipalidad con previa evaluación va a determinar dónde se puede vender el comercio ambulatorio".

Y con respecto a los rubros nos dijo "eso también está establecido en la ordenanza, nosotros trabajamos esta ordenanza en base de lo que dice Lima Metropolitana y ellos establecen giros para el comercio ambulatorio, por eso les hablaba del comercio ambulatorio modulado, que entra allí, anticucho, picarones, mollejas, todos los derivados de estos, llaves, cerrajerías, artesanías, también es otro de los rubros, lustrabotas, desayunos, emolienteros, que ellos tienen su propia ley y los canillitas y los que venden periódico, hay rubros que no son considerados como comercio ambulatorio, hay cosas que si se van a tener que erradicar definitivamente".

\subsubsection{Requisitos para formalizarse}


1. Presentar una solicitud por mesa de partes de la Municipalidad de Villa María del Triunfo, esa solicitud tiene carácter de declaración jurada, tiene que incluir el número de DNI, dirección, dirección del establecimiento.

2. Adjuntar un croquis de la ubicación.

3. Pertenecer a una asociación, esta asociación debe estar debidamente registrada con su RUS en la municipalidad.

4. Pasar previamente una evaluación socioeconómica que indique que esta actividad es su único medio o sustento de ingreso familiar.

5. Hay una tasa que se paga de acuerdo a lo que establece el TUPA, el monto es de 90 soles, este pago es anual.

\subsubsection{Acciones tomadas hacia los ambulantes informales}

Han pasado varias gestiones en la municipalidad y no han hecho nada con respecto a los ambulantes.

Según el Sr Luis vendedor formal "A habido enfrentamiento anteriormente, ya que se le dice que no se ubiquen en las zonas alrededor del mercado, pero la gente ambulante, es de otra zona chorrillos, San Juan de Lurigancho y no se puede tratar, y dejamos que la fiscalía intervenga, ya que es la función netamente es de la municipalidad"

Según el Sr Miguel Ángel Presidente del Mercado, "ustedes han visto en estos últimos días, la municipalidad ha hecho un trabajo de erradicar el comercio informal, eso ha sido como resultado también por la decisión política que tiene la nueva autoridad y las coordinaciones que hemos hecho con ellos, ellos son los que regulan el comercio formal e informal ya que también acuérdese que hay asociaciones de venta de anticuchos de naranjas, son asociaciones que ellos sí están regulados, el problema está en que en forma discriminada ocupan todo una vía y eso malogra el ornato de la ciudad y eso le corresponde a la municipalidad"

La Municipalidad amparada por la ordenanza No 049-2008 / MVMT que dice que la zona alrededor del mercado es zona rígida a través de sus fiscalizadores dispuso la salida de todos los ambulantes informales alrededor del mercado San Francisco. 
Esto comenzó, aproximadamente en la quincena de enero de este año con la nueva gestión municipal. Los fiscalizadores continúan desplegados alrededor del mercado de lunes a domingo desde las 7 am hasta las 7pm. Sin embargo apenas se van los fiscalizadores los ambulantes regresan a vender sus productos (trabajo de campo, enero y febrero del 2019)

Según el Sr Miguel Ángel Presidente del Mercado nos dijo “ Le voy a comentar algo que mis directivos tienen conocimiento, nosotros con la finalidad de ayudar a la autoridad, tenemos espacios en el segundo piso para que los señores (ambulantes) que están afuera ingresen al mercado porque nosotros pensamos que en un momento la municipalidad se va a cansar de mandar de 10 a 15 hombres (fiscalizadores) y todo el trabajo realizado en este mes de enero que ha terminado va a irse al agua porque nuevamente van a salir (los ambulantes a trabajar a la calle), entonces la cooperativa San Francisco ofrece sus espacios que tiene en el segundo piso para que ellos puedan estar comercializando"

El Sr Pedro Vílchez de la Municipalidad nos dijo " Estamos trabajando ahorita, en la elaboración de un proyecto de ordenanza que pretende ordenar y formalizar todo el comercio ambulatorio en todo Villa María del Triunfo, tenemos una ordenanza del 2008 que ya está desfasada podríamos decirlo y no cumple con las expectativas que tiene la ciudad, la ciudad a crecido demasiado y a crecido de una forma desordenada y ahorita estamos justo trabajando en un proyecto de ordenanza para poder encauzar y establecer unas zonas rígidas, algunas zonas rígidas para que esto no se desarrolle de una manera desordenada" y "Claro que si, ese es una de las normas que estamos estableciendo en esta ordenanza, nosotros como desarrollo económico, tenemos la función de capacitar y fomentar, el desarrollo económico en todos los sectores del distrito y uno de ellos es brindándoles capacitaciones con alianzas estratégicas, con empresas, con ONGs, con distintas entidades pues que puedan darle una buena capacitación para que puedan tener una mejor calidad de vida y puedan expender sus productos de alimentos".

\subsection{SUNAT}

La Superintendencia Nacional de Aduanas y de Administración Tributaria SUNAT, es un organismo técnico especializado, agregado al Ministerio de Economía y Finanzas. La SUNAT tiene como fin, administrar, aplicar, fiscalizar, sancionar y 
recaudar los aranceles y tributos del Gobierno Central. Fue creada el 7 de junio de 1988, siendo presidente Alan García Pérez.

La SUNAT tiene varias funciones, como la administración de los impuestos, así también como el control de las aduanas y administrar todos los tributos internos excluyendo los tributos municipales.

\subsubsection{Marco Legal \\ Impuesto general a las ventas (IGV)}

El impuesto general a las ventas (IGV) es un impuesto de alcance en todo el país, este impuesto que no es acumulable se grava a las ventas, en las prestaciones de servicios e importaciones de bienes que se realizan en nuestro país. Cabe indicar que el IGV es asumido o pagado por el consumidor final, es un tributo impuesto por el Estado a todos los usuarios o consumidores finales involucrados en el proceso de la producción o comercialización de productos, al comprar un producto el IGV está incluido en el precio.

EI IGV adquiere gran importancia porque genera para el Estado la más alta recaudación en lo que se refiere a ingresos tributarios, es considerado un impuesto indirecto, porque el que lo asume es el contribuyente final y no el contribuyente, ya que es un tributo nacional es obligatorio realizar su declaración y pago por haber efectuado transacciones afectas, la Sunat es la entidad que administra este impuesto, se le considera no acumulativo porque considera cada fase del proceso económico para gravar el valor agregado.

El 18\% del IGV está estructurado de la siguiente manera:

$16 \%$ Operaciones gravadas con el IGV

2\% Impuesto de Promoción Municipal (IPM)

\section{Impuesto Selectivo al Consumo (ISC)}

Es un impuesto que solo grava a ciertos bienes, se puede considerar que es un impuesto específico, la intención del Estado al aplicar este impuesto es desalentar el consumo de aquellos productos que afectan negativamente en nuestra sociedad en lo que se refiere social, individual y medio ambiente. Este impuesto busca también aplicarlo al consumidor que posee una mayor capacidad de poder contribuir por eso se aplica en los bienes de lujo como por ejemplo al comprar autos nuevos. 
Entre los productos gravados con el ISC tenemos:

- Bebidas alcohólicas

- Juegos de casino

- Máquinas tragamonedas

- Bebidas azucaradas

- Tabaco

- Combustibles

\section{Arbitrios Municipales}

Son tasas que el poblador de una comunidad paga debido al mantenimiento de los servicios que brinda la municipalidad como la limpieza pública, cuidado de parques y serenazgo. Así como este tributo, la municipalidad puede modificarlos, crearlos y exonerarlos ya que tiene potestad para hacerlo. Todos los contribuyentes deben realizar el pago anual de este tributo para poder sostener los servicios antes mencionados, cabe indicar que el cobro en locales como hoteles o restaurantes no son los mismos a comparación de una casa.

Para tener la idea completa estos son los criterios a considerar para determinar el cobro de los arbitrios:

- Intensidad del servicio (si está dividida en varias casas en su interior)

- Cercanía a parques o áreas verdes

- El tipo de actividad que realiza el predio

- Área del predio

- Valorización del predio

\section{Impuesto a la propiedad}

Son impuestos aplicados a la propiedad, es muy usual que los gobiernos locales como las municipales lo ejecuten para recaudar impuestos. Estos impuestos son utilizados para financiar los servicios que prestan los gobiernos locales, incluyen bibliotecas públicas, recolección de desechos entre otros.

3.7.2. Acciones gubernamentales contra la informalidad comercial

El gobierno central, conforme a la Constitución, tiene la autoridad de aplicar en nuestro país un sistema tributario en el cual puede crear, modificar o anular los tributos que sean necesarios, para atender los servicios públicos y el buen funcionamiento de la economía nacional. Es así que los tributos se crean, cambian y 
anulan. También se pueden establecer exoneraciones exclusivamente por leyes o decretos legislativos en caso de delegación de facultades, salvo los aranceles y tasas, los cuales se regulan mediante decretos supremos (Ministerio de Economía y Finanzas). Por lo tanto, todas las empresas naturales y jurídicas están en la obligación de contribuir ante el Estado, cuyo ente recaudador es la Superintendencia de Administración Tributaria (SUNAT). Según el INEI, la pobreza alcanza un 44.50\% a nivel nacional. Mucha gente sin trabajo busca obtener ingresos económicos con sus propias ideas de negocios. Pero, encuentran difíciles obstáculos en los altos tributos y complicados trámites. En este entorno, la gestión tributaria se encuentra entre los principales factores que han ayudado a una amplia informalidad a nivel nacional.

Las empresas en donde trabajan los peruanos han llegado a un 65\% de informalidad y en su mayoría tienen menos de cinco trabajadores. El problema de la informalidad en el Perú, pese a que en los últimos gobiernos se han lanzado leyes y programas que no han resultado atractivos, es hoy más agudo que en otros países como Ecuador o República Dominicana que están en la cola de la región. Durante años los intentos de subsistencia en el Perú, empezados para cubrir necesidades básicas ante la falta de empleo remunerado, hicieron que los programas del gobierno tengan como fondo la solución de la pobreza con el impulso de pequeños negocios, pero sin llegar del todo a la formalización.

Para el presidente de la Cámara de Comercio de Lima en el 2014, Samuel Gleiser, el nivel tan alto de informalidad no desciende porque no hay una política de Estado que haga interesante la formalidad y que abrevie todo el reglamento. "Persisten las trabas burocráticas y un sistema tributario y laboral que no apoya el crecimiento de la pequeña empresa, sino que hace que esta se estanque", sostiene. Según el BBVA, 2017, en el Perú, más de dos tercios de los trabajadores son informales, sin embargo el documento también indica que ha habido una disminución de estos empleos desde el 2005 cuando estaba cerca del 84\%, pero la tasa de informalidad sigue siendo elevada, está cerca del $71 \%$. Esto significa que más de 7,5 millones de personas laboran en condiciones informales en nuestro país.

A partir de información del Banco Mundial y del Fondo Monetario Internacional sobre la tasa de informalidad laboral y el PBI por habitante (medido en 
términos de paridad del poder adquisitivo) para distintos países, el BBVA Research concluye que un país con las características del Perú debería tener una informalidad laboral en torno al $40 \%$. Por lo tanto, no solo la informalidad laboral es alta, sino que parece ser también mayor que la de otros países con características similares.

La ministra de Trabajo y Promoción del Empleo (MTPE), Sylvia Cáceres dijo "que las políticas aplicadas en gobiernos anteriores para reducir la informalidad en las microempresas no han tenido un impacto efectivo" (El Comercio, Enero 2019), la disminución de la informalidad ha sido elegida como una de las principales metas del gobierno, pero la formalidad tiene varias dimensiones. Dependiendo de qué negociaciones se hacen incumpliendo las normas legales vigentes, se hablará de diversas clases de informalidad. Así tenemos, que existe informalidad empresarial, tributaria y laboral. Algunas veces los tres coinciden, otras no. Para comprenderlo mejor, hay empresas que no trabajan bajo la normatividad de su sector hay otras que sí lo hacen, pero no pagan sus impuestos y tienen trabajadores dependientes que no tienen sus derechos laborales. Los tipos de informalidad, tienen cada una sus propias causas. La informalidad minera, pesquera, industrial, de construcción y servicios reflejan las normativas sectoriales, tributarias y laborales. Pero, sobre todo, reflejan la productividad de las firmas y las personas.

La informalidad laboral se divide en dos partes, la de empleados dependientes que pueden trabajar en empresas formales como en las informales y la de los trabajadores independientes que tienen RUC. Los independientes informales, son los que trabajan y no tienen RUC como taxistas, estibadores de mercado, recicladores, cobradores de combi, choferes, gasfiteros, obreros de construcción civil, lava carros, guardianes. Los trabajadores dependientes informales son cerca del $40 \%$ de la fuerza laboral. Casi la mitad de ellos trabaja en empresas formales y la otra en empresas informales. Sin embargo, la mayoría (el 30\%) son trabajadores independientes. El gobierno ha propuesto que con diferentes esquemas tributarios (Impuesto a la Renta e IGV), las empresas logren formalizarse primero, luego paguen sus impuestos y puedan contratar trabajadores con las leyes laborales vigentes.

\subsubsection{Proceso para formalizarse}


El tener un negocio propio y ser tu propio jefe es el sueño de muchas personas emprendedoras, ser independiente, manejar su tiempo y lograr sus objetivos. Antes de comenzar un negocio se debe evaluar el tipo de negocio que se realizará, el capital inicial o como va ser financiada, si el producto o servicio que se brindara tendrá la aceptación de los posibles clientes y las obligaciones tributarias que se tendrá. Es necesario que se identifique el tipo de actividad económica del negocio que se va a iniciar, porque tiene relación con las obligaciones tributarias que se debe cumplir.

Saber quiénes serán sus potenciales Clientes
a. Personas
b. Empresas
c. Instituciones Públicas

Se debe tener en cuenta:

El tipo de público (o cliente que tendrá su negocio) es importante para poder elegir los tipos de comprobantes de pago que se usará.

Saber qué tipo de empresa puede crear:

Se puede optar por desarrollar su actividad empresarial como persona individual o como persona jurídica (empresa), considere sus características:

Persona individual:

a. La persona ejerce todos los derechos y asume todas las obligaciones a su nombre

b. La responsabilidad se extenderá a todo tu patrimonio personal

c. Solo requieres obtener el RUC, no requiere escritura pública de constitución

Funciona como una persona con negocio.

Persona Jurídica (empresa):

a.La empresa es quien asume todos los derechos y obligaciones de la misma.

b. La responsabilidad quedará limitada al patrimonio de la empresa

c. Requiere una escritura pública de constitución y que se inscriba en registros públicos 
d. Funcionamiento como una empresa que puede ser tipo Empresa individual de responsabilidad limitada (EIRL) Sociedad Anónima o de Responsabilidad Limitada

Requisitos

a. Inscribirse al RUC a cargo de la SUNAT

*En el caso de empresas, debe inscribir previamente en los Registros Públicos. Obtener autorizaciones complementarias (permisos especiales, licencia de funcionamiento, entre otros)

b. Obtener los comprobantes de pago y libros contables que corresponda.

No olvidar considerar:

Antes de iniciar su negocio, debe haberse inscrito en el RUC y tener sus comprobantes de pago, así como tener aprobadas las autorizaciones administrativas y/o permisos especiales, sólo si lo necesita según el giro de su negocio, permiso de funcionamiento, autorizaciones de plantillas de trabajo correspondientemente a fin de evitar sanciones de multa, cierre u otras.

Otro, es comprobantes de pago y libros contables, obtener comprobantes de pagos, obtener y legalizar libros contables así ayudando tanto a las autoridades y al negocio para tener un registro tanto en el movimiento de dinero como en la producción que se tiene, para que sea más eficiente y organizado teniendo un proceso controlado del negocio (SUNAT).

\subsubsection{Evasión Tributaria relacionada con la informalidad}

La informalidad trae consigo una serie de consecuencias negativas para nuestra sociedad:

- Los menores ingresos que percibe el Estado limita sus posibilidades para satisfacer las necesidades básicas de la población y/o mejorar los servicios públicos.

- Origina una situación de desigualdad y competencia desleal entre actividades formales e informales ya que el costo de la formalidad no es asumido por quienes realizan actividades informales. Por tal motivo, estos últimos pueden reducir sus precios y competir deslealmente con quienes venden los mismos productos o prestan los 
mismos servicios respetando todas las obligaciones establecidas por nuestra legislación.

- Influye en un mayor desempleo y/o subempleo. Por su propia naturaleza las actividades informales difícilmente incorporan empleo formal. Además, las empresas formales que compiten con estas actividades se ven obligadas a reducir costos, generalmente, a través de la reducción de personal, la contratación de menos trabajadores o de la utilización de formas de empleo precario.

- Atenta contra una correcta toma de decisiones políticas y/o económicas por parte del gobierno central ya que limita la planificación y la proyección de las variables económicas del país. Esto se debe a que las actividades informales no forman parte de las estadísticas oficiales.

Los componentes de la economía informal según estudios De la Roca \& Fernández (2004) son:

- Evasión tributaria pura

- Trabajadores informales

- Economía irregular

El sector informal está formado por unidades productivas que no poseen personería jurídica ni llevan sistemas de contabilidad (MTPE, 2004) el cual muestra que la producción de la economía informal con cálculos del PBI llegó a un 10,1\% en el 2002. (INEI, 2014)

Teniendo en cuenta la pronta evolución de la informalidad, (De Soto 1989) Hernando de Soto, nos dice "la informalidad se produce cuando el derecho impone reglas que exceden el marco normativo socialmente aceptado, no ampara las expectativas, elecciones y preferencias de quién no puede cumplir tales reglas y el Estado no tiene la capacidad coercitiva suficientes". Por lo que frente al desamparo los sujetos se ven obligados a utilizar herramientas extralegales.

Puede darse el caso de que una empresa sea formal y fabrique bienes reconocidos como legales pero que no cumpla los requisitos de contratación formal de sus trabajadores, o que los trabajadores formales reciban ingresos extras no declarados, lo cual explica la dificultad del problema. 
Asimismo de acuerdo a Lagos (1995), en los años ochenta en América Latina en particular, informalidad e ilegalidad eran tomadas como sinónimos. Se utilizó el término Informalidad para referirse al conjunto de actividades que eran ilegales ya que no cumplían con las regulaciones económicas, aspectos fiscales, de condiciones de empleo, salud, etc. Es así que este problema del sector informal fue vista como causada por trabas en la ley, la regulación y el sistema tributario. El Sr Miguel presidente del Mercado San francisco nos dijo: "pienso que ellos no quieren pagar impuestos (ambulantes), no quieren pagar local, falta de orientación, también porque ha sucedido que en otros distritos le han dado la oportunidad de 1 a 2 años de ellos comprar su terreno y ellos pagar pero eso no ha ocurrido, la mayoría de la gente informal que tenemos alrededor son de otros distritos, no son ambulantes, son mayoristas. Vienen con camionetas llenas de verduras, lleno de fruta, triciclos llenos. Ambulantes se dice a la persona que trae un plástico y lo tira al suelo y vende contado sus cosas pero los que están alrededor nuestro en la avenida san José, y en la avenida Olaya son mayoristas"

El Sr. Pedro Vílchez de la Municipalidad nos dijo "Esto perjudica al distrito, porque se deja de recaudar impuestos, y los impuestos para poder brindar un mejor servicio a la población, nosotros dejamos de recibir impuestos, dejamos de dar nuestro servicios a la población, eso sería el inconveniente"

\subsection{Ser formal en el Perú}

\subsubsection{Importancia de ser comerciante formal}

La informalidad interviene de manera negativa en la recaudación y restringe la provisión de recursos que el Estado necesita para su funcionamiento y la atención de las exigencias de la sociedad.

Entendemos por informalidad aquellas actividades económicas en las que no se respetan los formatos establecidos en la legislación vigente como, por ejemplo, no inscribirse en el Registro Único de Contribuyentes (RUC), no obtener Licencia Municipal de Funcionamiento o no presentar declaraciones juradas de impuestos cuando es debido.

Desde este enfoque, el tema de la informalidad no debe ser tocado en base a las personas sino, más bien, a las actividades económicas que éstas realizan. En este respecto, puede ser que una misma persona realice más de una actividad 
económica y actúe formalmente en una e informalmente en la otra. Así, tenemos que, se puede dar el caso de un profesional que trabaja de manera independiente y cumple con todas sus obligaciones tributarias, sin embargo, adicionalmente, tiene un negocio de venta zapatos que no está registrado ni paga tributos.

Cuando se emprende un negocio instintivamente hacemos un análisis del costo-beneficio de las alternativas que se presentan. Dos son los aspectos en los que se debe trabajar con la finalidad de reducir la informalidad y aumentar la base tributaria: la reducción de costos y el incremento de beneficios de la formalidad.

Entre los beneficios que tiene trabajar de manera formal, podemos nombrar:

Admite ser sujeto de crédito para el sistema financiero. Uno de los requisitos o cláusulas exigidos a las personas para obtener un crédito, ya sea sí trabajan independientemente o si tienen un negocio, consiste en demostrar los ingresos percibidos y el respeto de los compromisos asumidos. En este sentido es indispensable inscribir la actividad económica en los registros de la Administración Tributaria y cumplir con las obligaciones tributarias dispuestas por las leyes vigentes a fin de poder obtener un préstamo financiero.

Es necesario evitar ser objeto de sanciones por el incumplimiento de las normas vigentes, incluyendo las de carácter tributario.

Un beneficio de ser formal, es que abre las oportunidades de una mayor demanda de los productos que se venden o servicios que se prestan. Trabajar formalmente hace posible contar con un mayor número de clientes y, por lo tanto, de ingresos, ya que siempre las empresas formales y entidades del Estado eligen como proveedores a personas que desarrollan su actividad económica de manera formal.

Esta es una manera real de redistribuir la riqueza (más tributos paga quien mayor capacidad contributiva o ingresos tiene). El preciso y puntual pago de los tributos permite al Estado obtener los recursos para buscar la satisfacción de las necesidades básicas de aquel sector de la población de bajos ingresos.

El ser formal brinda la autoridad moral para exigir servicios públicos de calidad. El cumplir con cada una de las obligaciones que tenemos como ciudadanos nos autoriza a exigir nuestros derechos.

La innovación de un sistema tributario simple, ágil, técnico y justo, así como de un servicio más eficiente a la población por parte de la Administración Tributaria 
disminuirá significativamente los costos de la formalidad. Esta ocupación debe ir acompañado adicionalmente de un trabajo de orientación, difusión y de formación de conciencia a todos los niveles.

La SUNAT ha realizado un trabajo importante en estos últimos 10 años, creando así el Registro Único de Contribuyentes, un sistema de pago a través de la red bancaria, la Transferencia Electrónica de Fondos en el cual el pago se hace sin formularios. Se simplificaron también los trámites de inscripción en el RUC y se están creando centros de servicios a nivel nacional brindando una atención con rapidez y eficiencia, se están dando facilidades de pago para deudas atrasadas y se está tratando que la relación SUNAT-Contribuyente sea más justa, creando la Defensoría del Contribuyente.

Por otra parte, se hace una fiscalización en todos los niveles de negocios o empresas, acompañado de un apropiado régimen de sanciones, aumentando los costos de la informalidad. Actualmente, la SUNAT ha cambiado su sistema de programación de las verificaciones y/o fiscalizaciones, utilizando criterios eminentemente técnicos ha modificado el régimen de gradualidad de sanciones para otorgar ciertos beneficios en el caso de la subsanación voluntaria de infracciones, siendo más drásticos en los casos de reincidencia.

Si bien es cierto, la existencia de menores costos para formalizarse y los mayores costos que conlleva mantenerse en condición informal favorecerá una mayor formalidad, un factor fundamental será el grado de conciencia tributaria que exista en la población para asumir la tributación como un componente de la vida en sociedad. Por lo tanto, unos asumirán por convencimiento propio la necesidad de formalizarse y otros, que son formales, exigirán el cumplimiento de las obligaciones de cada actividad.

\subsubsection{Costos y tiempos para constituir un negocio}

Pierre Doubert asociado de Pizarro, Botto \& Escobar Abogados, nos da ocho pasos para constituir un negocio propio

\section{Verificación y Constitución}

Primero, se debe verificar que el nombre con el que se desea nombrar a la empresa esté disponible. Para esto, se irá a Registros Públicos. Si está disponible el nombre se trabajará en la constitución del negocio. 
Si se quiere formar una sociedad, se nombrará a los accionistas fundadores, la participación que le corresponderá a cada accionista, el objeto social de la empresa y los principales funcionarios.

\section{Costos}

No hay un cantidad preestablecida para la creación de una empresa. Depende de los honorarios de la notaría con la que se trabajara, el monto del capital social inicial, también de las tarifas que cobra Registros Públicos, las cuales se basan en una tasa del monto del capital social.

\section{El giro del negocio}

Se deben determinar con exactitud, las actividades económicas a las que se dedicará la empresa y esto lo deben determinar los socios fundadores, la Sunat al realizar el trámite de inscripción de la empresa ante el RUC, pedirá que se indique las actividades económicas a los que se dedicará la empresa.

\section{Capital mínimo}

La ley no pide un capital inicial mínimo. Sin embargo, para la formalización de la empresa se necesita depositar el capital social en un banco, monto que depende del mínimo que exigen para abrir una cuenta corriente, según el banco con el que se trabaje.

\section{Tipo de organización}

La más utilizada y recomendable para empezar un negocio es la Sociedad Anónima Cerrada (SAC), si son más de dos accionistas, o la Empresa Individual de Responsabilidad Limitada (EIRL), en caso el empresario quiera ejercer el control de la empresa el mismo.

\section{Domicilio fiscal}

No se necesita tener un local propio o alquilado para tener el RUC de la empresa, generalmente se emplea como domicilio fiscal el domicilio de uno de los accionistas

\section{Plazos}

El trámite dura tres semanas, de la constitución de una empresa y de la obtención del RUC, siempre y cuando no hubieran observaciones.

\section{Licencias adicionales}


En la constitución de una empresa no se requiere de licencia municipal. Pero, si cuando la empresa empiece a operar formalmente, sin ese requisito, no podrá obtener la licencia de funcionamiento ante la municipalidad.

\subsection{Campañas}

\subsubsection{Antecedentes Nacionales}

\section{Campaña contra la informalidad en Trujillo}

Según, lo que había ofrecido el Alcalde de Trujillo en su campaña electoral, el 15 de enero de este año dejo sin ambulantes el centro historico de la ciudad de Trujillo dando confianza y credibilidad a su gestión.

Para realizar este cambio, contó con la ayuda de los trabajadores, funcionarios y la Policía Nacional del Perú, la estrategia del Alcalde ha sido buena porque no ha usado la fuerza para desalojar a los ambulantes. A utilizado anuncios, comunicados difundidos por los medios de comunicación, redes sociales y el boca a boca.

Para este fin llegaron Municipales y Policías a la avenidas España, Gamarra y Grau, para que los ambulantes no ocupen las calles. Sin embargo, muchos de los comerciantes informales son dueños de grandes tiendas que invaden las calles y generan basura, desorganización y desorden.

Los informales que invadieron las calles por años, en su mayoría son comerciantes con grandes puestos en las calles, mueven mucho dinero y no pagan ningún sol en impuestos, no pagan alquileres de local, planillas de trabajadores y son una competencia desleal con las tiendas formales, no respetan la ley (Portal de noticias Gaceta Ucayalina, 2019)

\subsubsection{Antecedentes Internacionales}

\section{CREZCAMOS JUNTOS}

Esta Campaña comenzó en el gobierno de la república mexicana ya que se observó que la economía informal en las familias mexicanas generaba que el PBI llegará a un $25 \%$ siendo 60 millones de personas en el país.

Este programa, se dio a conocer por todos los medios de comunicación e informaron sobre los beneficios que tendrían al formalizarse, en su economía en su seguridad social y en financiamiento para el negocio. 
El presidente Enrique Peña Nieto dijo que se firmaría un decreto en el cual se simplificaría los regímenes de incorporación y se tendrían beneficios y facilidades para que puedan entrar a la formalidad comercial en la sociedad, dándoles la facilidad de no pagar el primer año la SAT, y se le da descuentos en los 9 años siguientes haciendo así que puedan ir creciendo su empresa sin tanta dificultad Se dan beneficios si venden 100,000 y 2mdp, evitando pagar el IVA y IEPS.

Además tendrían facilidades como servicios médicos y de seguridad del IMSS, así se puede comenzar a ahorrar para tener un crédito hipotecario del Infonavit y poder conseguir crédito para su negocio con la Nacional Financiera, créditos de consumo con la Infonacot y tienen apoyo para que pueda crecer su empresa con la Inadem.(Gobierno de México)

En el 2012 por medio a un estudio se vio que en los años 2003 al 2012 un $25 \%$ de PIB era de la economía informal llegando a un $60 \%$ de la población entrara en ese sector (INEGI, 2012).

Por eso el objetivo de la campaña es recuperar el valor de la formalidad como un valor social, que implica legalidad, oportunidad y crecimiento (Luis Videgaray, Secretario de Hacienda, 2014).

\section{SI A LA FORMALIDAD}

Esta Campaña se realizó en Colombia, tenía como concepto concientizar a las personas sobre la importancia de ser formal, estar dentro de las leyes, cumplir y pagar impuestos al estado. Comenzó en el 2013 y aumentó en un 14\% las personas que quisieron entrar a la formalización apoyando así al crecimiento de la sociedad.

La segunda etapa de esta campaña: Sí a la Formalidad se hizo en el 2014. Según Rodrigo Estrada (2014) "A partir del año 2014 iniciamos la segunda etapa de esta campaña: Sí a la formalidad. Las razones para ser formal son sólidas en el momento coyuntural que vive nuestra región. La formalidad genera confianza, respaldo legal, posibilidades de formación permanente, crédito y reconocimiento empresarial; entre otros aspectos, que debe tener en cuenta una persona para legalizar su organización"

Se dice:

a. Sí a la formalidad, por la seguridad y la confianza que genera a los empleados del empresario y a sus clientes" 
b. Sí a la formalidad porque garantiza y hace pública la calidad del comerciante.

c. Sí a la formalidad porque ya no recibe penas legales de la alcaldía, la Dian y la Superintendencia de Industria y Comercio.

d. Sí a la formalidad porque el empresario y su empresa tienen el respaldo de la Cámara de Comercio de Armenia y del Quindío.

e. Sí a la formalidad porque puede tener acceso a programas empresariales avalados por el Gobierno, permite la ejecución de negocios con el sector público y el privado, y la participación en licitaciones y obtención de créditos ante entidades financieras.

f. Sí a la formalidad porque genera mayores oportunidades de acceder a mercados nacionales e internacionales y a capacitaciones gratuitas en diversos temas. Los ciudadanos también deberán decir sí a la formalidad comprando a los comerciantes que dieron el paso a la formalidad.

Se debe ser formal porque se obtiene seguridad y confianza para los empleados y clientes, porque confirma y hace pública la calidad del comerciante, porque demuestra la historia y legalidad de su actividad comercial por medio del certificado que expide la Cámara de Comercio, porque posibilita el logro de créditos y otros beneficios comerciales, porque permite acceder a programas y eventos empresariales apoyados por el Gobierno, porque puede participar en capacitaciones empresariales gratuitas y otros servicios que ofrece la Cámara de Comercio, porque le es más fácil participar en licitaciones y la celebración de negocios con los sectores público y privado, porque gesta mayores posibilidades de acceder a mercados nacionales e internacionales y porque se evita tener sanciones legales de la Alcaldía, DIAN y Superintendencia de Industria y Comercio.

Se debe comprar a los comerciantes formales porque con su compra apoyará a las empresas que generan desarrollo, porque contribuirá a lograr una mejor economía, porque su aporte ayudará a generar empleo formal para más personas, porque ayudará a reducir la competencia desleal de los informales, porque comprará productos garantizados, porque es un deber de las personas de bien, porque se dará un ejemplo a las futuras generaciones, porque así evitaríamos problemas de salud por posibles productos en mal estado.

\subsection{Diseño gráfico como instrumento de información}




\subsubsection{Diseño gráfico}

El diseño gráfico es una profesión o especialidad, cuya función es satisfacer necesidades de comunicaciones visuales dedicadas a difundir mensajes determinados a grupos sociales con objetivos claros y específicos. Asimismo, diseño gráfico se conoce con el nombre de diseño en comunicación visual, diseño de comunicación visual o diseño visual.

Es importante el diseño gráfico porque se basa en que el mismo desarrolla variadas tácticas para conseguir una comunicación desde un enfoque visual; este hecho es de suma trascendencia según marketing, ya que se puede realizar variadas presentaciones que inmediatamente transmitirán valor a un potencial comprador.

\subsubsection{Diseño de información (infografía)}

El diseño para la información es utilizado para la fabricación de revistas, periódicos, libros, etc. también se emplea en la fabricación de señales de tránsito.

Las Infografías son medios gráficos que abrevian de manera simple y agradable bastante información en poco espacio.

Desde la época de los egipcios, se representaba la información en jeroglíficos con dibujos. Después, evolucionaron y pasaron por varias fases hasta que a comienzos del siglo XX se empezaron a utilizar de forma didáctica.

Las infografías son un complemento ideal para un contenido largo y difícil de entender, gracias a la infografía se puede abreviar los puntos principales y explicar los conceptos más complejos.

Sus principales características son: Significado propio, texto reducido, coherencia gráfica, legibilidad y linealidad.

\subsubsection{Que es el tótem}

El tótem según el diccionario de la Real Academia Española (RAE) se refiere al objeto o al ser que, en ciertos pueblos, era considerado como el antepasado o el protector del grupo. Así pues el tótem estaba vinculado al origen de la tribu, es decir los integrantes del clan descendían del tótem que podría ser un animal una planta o un objeto inerte. El término tótem surge de la lengua de un pueblo nativo de los 
Estados Unidos llamado Ojibwa y ellos hacían referencia a un monumento que se puede encontrar en la costa del océano pacífico en América del Norte.

Los tótem son esculturas usando figuras de animales, objetos e incluso personas, esculpidas por los indios. Algunas tribus registran la historia de un grupo utilizando para esto los tótemes.

Cuando se habla de un tótem, se puede referir a un objeto de madera o de piedra al cual se le atribuye un poder místico. La Madera utilizada para hacer los tótem era el cedro el cual podía soportar cambios de clima extremos, el cuerpo del tótem generalmente muestra personajes para declarar el rango del jefe de la tribu.

\subsubsection{Tótem fotográfico}

Es una cabina fotográfica tipo tótem, se utiliza mayormente para reuniones y eventos.

\section{CAPÍTULO IV}

\subsection{Estructura del Proyecto}

\subsubsection{Concepto del proyecto}

Los conceptos que se eligieron son el optimismo y el crecimiento, ya que se enfocan en el avance, desarrollo y mejora del distrito, comenzando por la compra responsable del público objetivo qué son los clientes que frecuentan el mercado. Se busca concientizar a los clientes del mercado para que compren a comerciantes formales que cumplen con las leyes, ya que con esto, ayudaran a que haya más ingresos a la municipalidad y a la Sunat para la mejora del país y del distrito.

Asimismo, los comerciantes informales ambulatorios, si hacen el cambio a la formalidad mejoraran su negocio, su estilo de vida y ayudarán al desarrollo del país.

\subsubsection{Nombre del proyecto}

El nombre del proyecto es "Vamos pa' lante", el nombre se eligió por ser una frase coloquial de barrio popular al igual que el concepto del logotipo, el cual identifica mucho el desarrollo de un pueblo pujante.

\subsubsection{Fundamentación del proyecto}

El proyecto se pensó en concientizar a las personas que viven en la zona especificada del distrito de Villa María del Triunfo, exactamente a las personas que 
frecuentan el mercado San Francisco, mostrando que comprar a ambulantes, afecta a la mejora del distrito.

La dinámica del proyecto es la construcción de dos tótem en forma de carteras para hacer compras, el cual se llevan al ir al mercado, el cual tendrá un tamaño 5 veces más grande del tamaño original, estas estarán puestas en puntos estratégicos dentro del mercado San francisco, ya que es un mercado muy frecuentado por el público objetivo en este sector de Villa María del triunfo. En los lados de la estructura de tótem, se pondrán fotos que se hicieron previamente, con una pequeña descripción y ubicación del problema, haciendo énfasis dentro de la fotografía el problema, que se está presentando.

A las personas que se acerquen a ver la exposición de fotografía se le pedirá hacer una corta encuesta en la cual se medirá qué tan impactante fue para ellos ver las fotos y si comprenden cual es el problema, también habrá unas preguntas extras, para las personas que sean comerciantes. Como obsequio por participar se le dará una pequeña bolsa de lona y un imán de refrigeradora con el logo de la campaña. También se estará entregando dos tipos de folletos, uno para compradores y otro para los ambulantes llegando así a los dos públicos objetivos más importantes.

\subsection{Público Objetivo}

\subsubsection{Actores involucrados en el problema}

\section{a. Comerciantes}

\section{Informales}

Comerciantes ambulantes que trabajan de forma ilegal, no pertenecen a ninguna organización, no pagan ningún tributo, no tiene un lugar fijo para trabajar, generalmente trabajan en las vías públicas.

\section{Formales}

Son Comerciantes de distintos rubros que cumplen con las leyes de la municipalidad, permisos de funcionamiento, pagos tributarios de la SUNAT y pagos de servicios, estos comerciantes son los que se encuentran dentro de las instalaciones del mercado san francisco

\section{Mercado San Francisco}

Grupo de comerciantes que se encuentran dentro de una Cooperativa, la cual cumple con las leyes comerciales, son formales y pagan impuestos. 


\section{Municipalidad}

Institución Pública, liderada por el Alcalde, regidores y gerentes de diferentes áreas, su función es administrar, gobernar y hacer cumplir las leyes que se han dado para el distrito.

\section{SUNAT}

Organización reguladora, que administra los tributos que se recaudan para invertir en obras para el país.

\section{Compradores}

Mujeres, madres de familia en su mayoría, de 30 a 40 años de edad, de un nivel socioeconómico $C$-D las cuales realizan sus compras diarias de alimentos para sus hogares y que viven en zona cercana del mercado San Francisco.

\subsubsection{Fundamentación del público objetivo elegido}

El público objetivo de la Campaña son los compradores, en su mayoría mujeres, madres de familia entre 30 a 40 años de edad con un nivel socioeconómico C-D que compran en el Mercado San Francisco

\subsubsection{Descripción del público objetivo}

\section{Clientes que frecuentan el mercado}

Los clientes son en su mayoría mujeres entre 30 a 40 años, hombres en menor cantidad entre 40 a 60 años. Generalmente son personas que viven cerca del mercado y es muy frecuentado por ser el más grande de la zona y porque atiende desde las 8 de la mañana hasta las 10 de la noche de lunes a domingo. El nivel socioeconómico es en su mayoría $C$ y $D$ y en una minoría se encuentra el nivel B.

\section{Características sociales}

Se realizó un trabajo de campo durante la investigación, lo que se componen de fotografías de los compradores que frecuentan el mercado San francisco de Villa María del Triunfo.

\section{Hábitos:}


Los clientes por ser de un nivel socioeconómico $\mathrm{C}$ y $\mathrm{D}$, hacen sus compras en forma diaria ya que no disponen del dinero suficiente para hacer sus compras para más días. Las compras generalmente lo hacen comparando precios ya sea en los puestos de ambulantes o dentro del mercado. Los clientes del nivel socioeconómico $B$, hacen sus compras generalmente dentro del mercado y lo hacen semanalmente $o$ cada 4 días, también hacen sus compras en supermercados cerca del distrito.

\section{Comerciante formal}

Los comerciantes que tienen sus puestos dentro del mercado y cumplen con las leyes, pagando sus impuestos. Son comerciantes de diferentes giros como frutas, verduras, carne, pollo, embutidos, ropa, zapatos, regalos, etc.

\section{Comerciante informal ambulatorio}

Son los comerciantes informales que trabajan en forma ambulatoria, puede ser que tengan un lugar fijo en la calle o trabajan caminando llevando sus productos en la mano o en carritos. Son comerciantes informales que no pagan impuestos y trabajan fuera de la ley.

\section{Características sociales}

Habitos:

Los comerciantes formales son respetuosos de las leyes, cumplen con los pagos a la Municipalidad y a la Sunat y tambien cumplen con los deberes que tienen hacia el mercado, respetando también horarios de trabajo. Generalmente son personas que son cabeza de familia y sus edades fluctúan entre 35 a 60 años aproximadamente. Los comerciantes informales son trabajadores fuera de la ley, no cumplen con ningún pago, huyen de los fiscalizadores de la Municipalidad, los productos que venden no son confiables, no cumplen con horarios de trabajo y si los clientes compran sus productos no habrá lugar a reclamo.

\subsection{Levantamiento de información}

\subsubsection{Fotografías de la situación del problema}




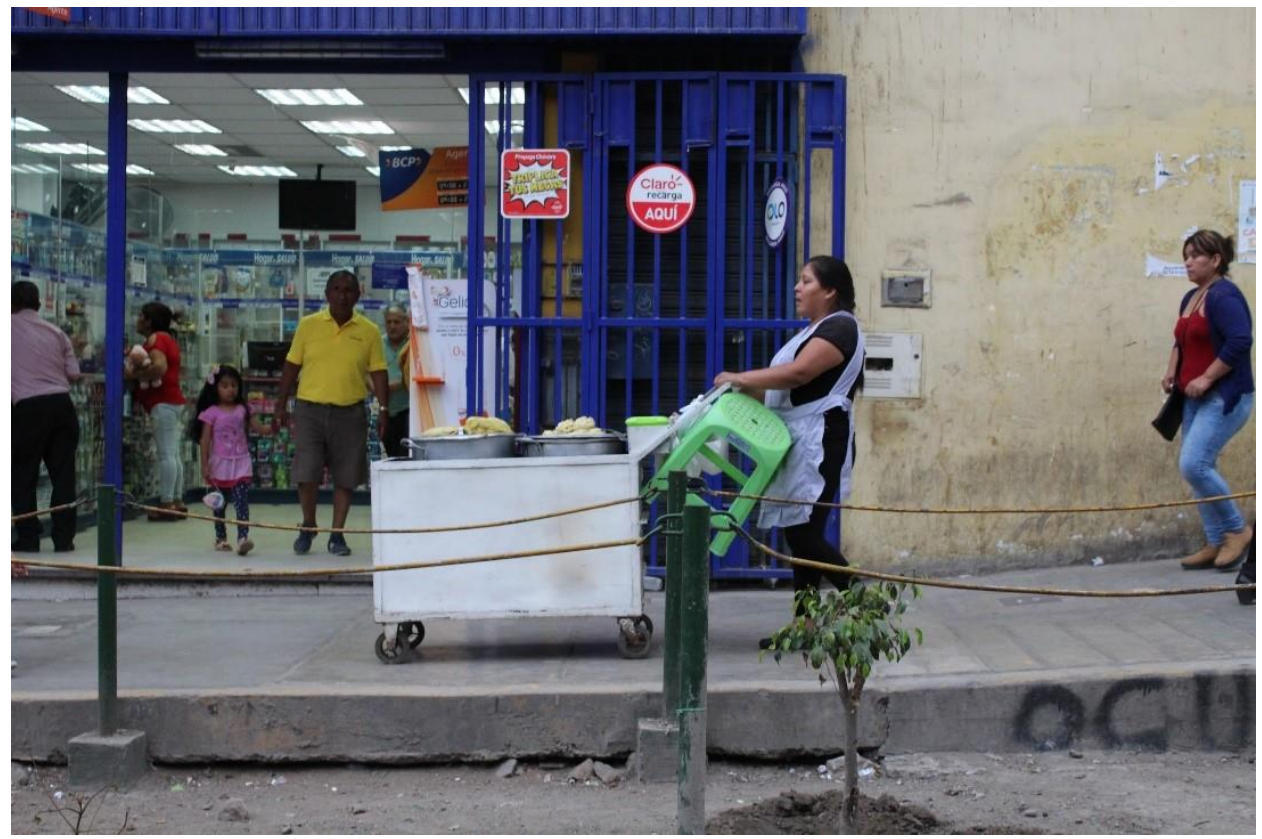



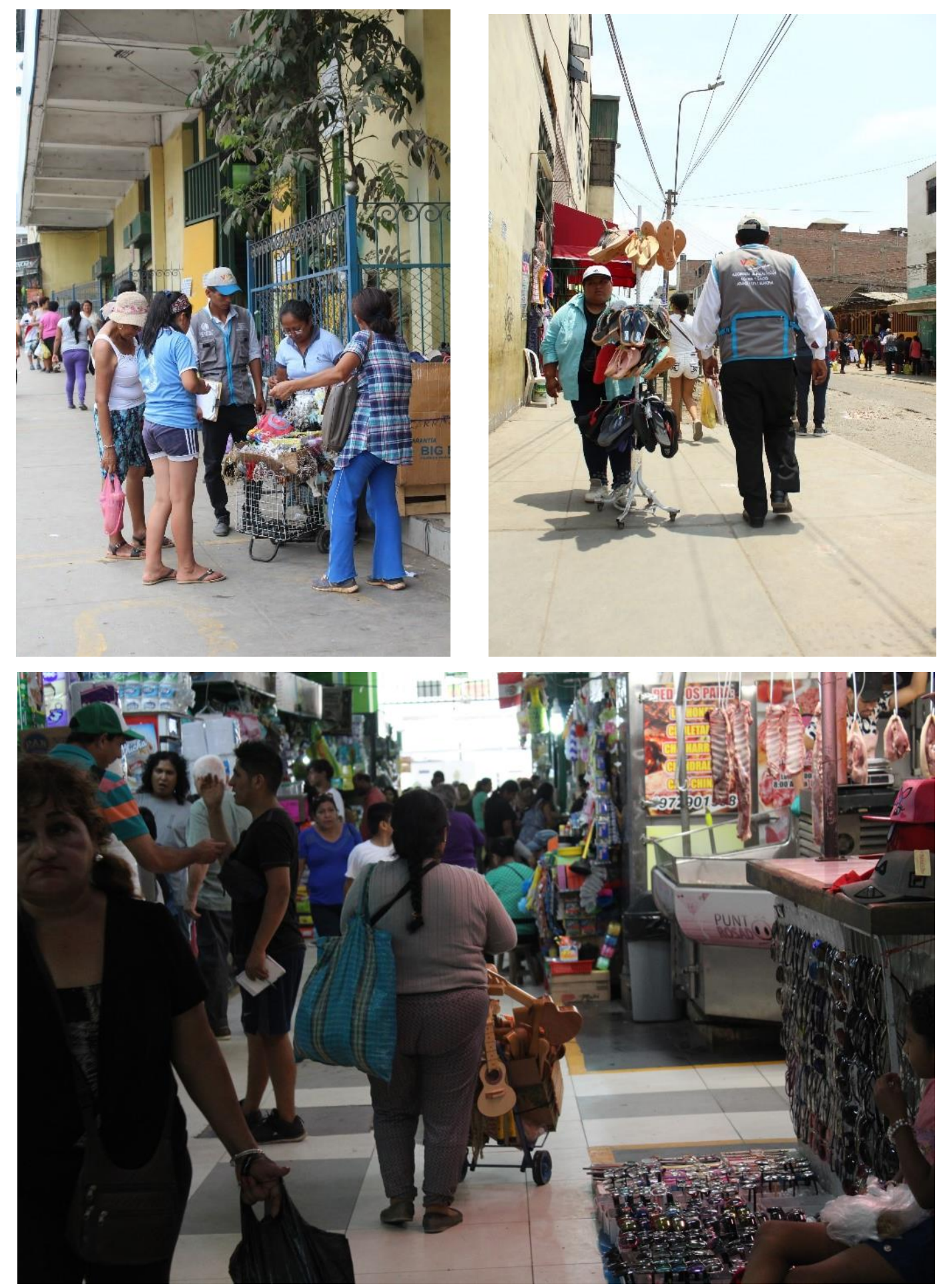

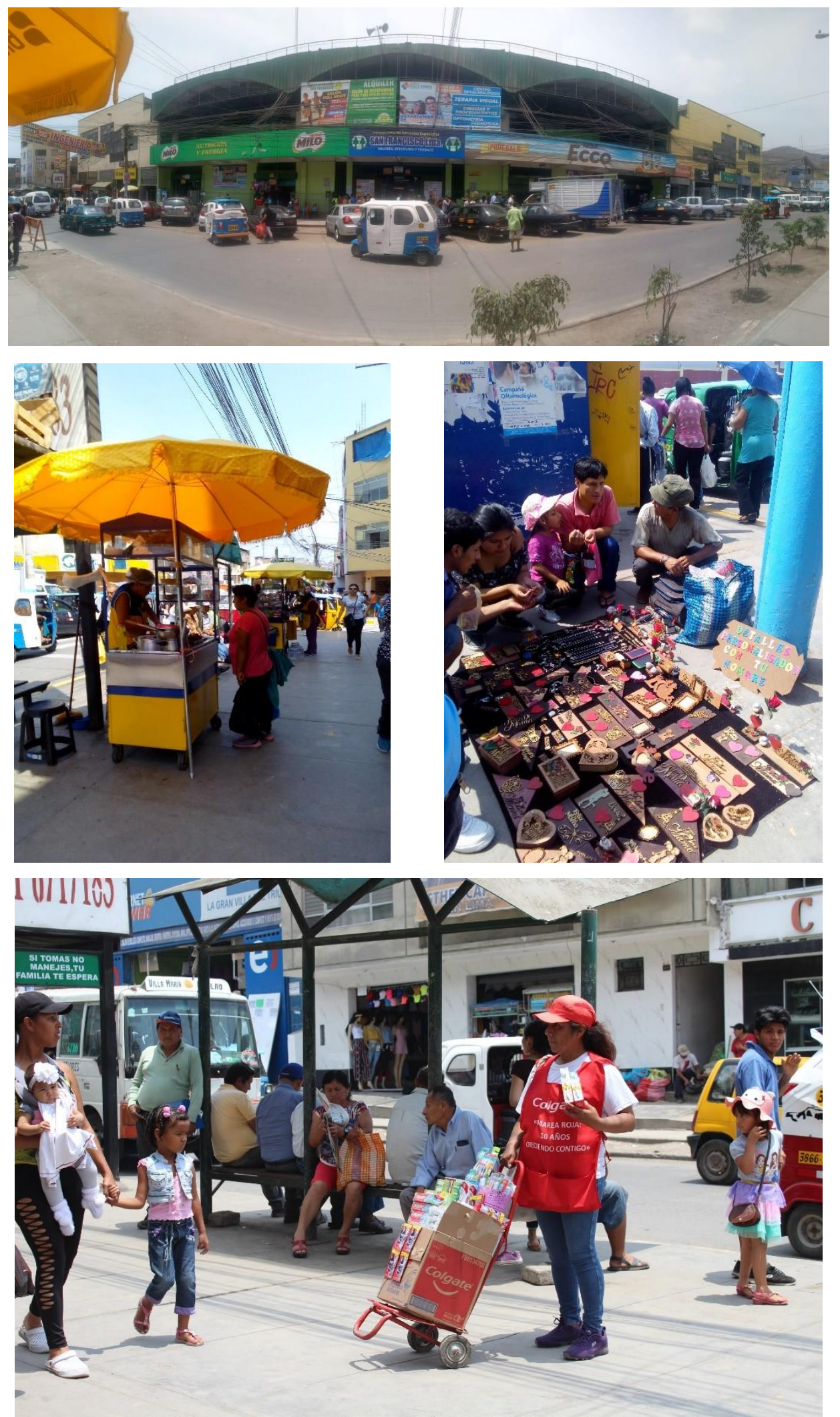


\subsubsection{Entrevistas a los protagonistas del problema}

\section{Entrevista 1}

Luis Ruiz

Ex - presidente de la Cooperativa de Servicios Especiales San Francisco Ltda. / actualmente Socio de la cooperativa ¿QUÉ PIENSA DE LOS AMBULANTES QUE SE ENCUENTRAN ALREDEDOR QUE NO ESTÁN DENTRO DE LAS LEYES DE LA SUNAT LA MUNICIPALIDAD DE VMT? ¿LE PERJUDICA?

Al respecto de cada gestión que ha habido de los alcaldes, 4 a 5 gestiones que han pasado, no han ejercido autoridad, las 3 zonas avenidas, son zona rígida así que la autoridades tiene que hacer cumplir las leyes del comercio ambulatorio alrededor del mercado, porque está prohibido pero hacen caso omiso a los ambulantes porque les cobran a los ambulantes, ya que perjudica el comercio internamente, dado que hacen compiten con otros o lo venden con un precio más bajo que nosotros los comerciantes formales, roban en el peso, productos al intemperie, no es igual que tener los productos en un local construido, mejor presencia, mejor conservación de los productos.

\section{¿HA HABIDO INCIDENTES QUE LE HA PERJUDICADO DIRECTAMENTE A USTED POR LOS COMERCIANTES INFORMALES?}

A habido enfrentamiento anteriormente, ya que se le dice que no se ubiquen en las zonas alrededor del mercado, pero la gente ambulante, es de otra zona chorrillos, san juan de Lurigancho y no se puede tratar, y dejamos que la fiscalía intervenga, ya que es la función netamente de la municipalidad.

\section{Entrevista 2}

Kreysi Mohina

Socia de la Cooperativa de Servicios Especiales San Francisco Ltda. ¿USTED CONOCÍA SOBRE QUE PAPELES SE NECESITAN PARA SER FORMALES?

en su totalidad no pero en parte sí porque mi mamá ya era formal, cuando necesite hacerlo ya sabía lo que tenia que hacer, ya sabia que llevar al contador, que tenía que pagar un derecho a la SUNAT, etc etc. 


\section{¿QUÉ PIENSA SOBRE LOS VENDEDORES AMBULANTES QUE NO ESTÁN PAGANDO IMPUESTOS?}

Que ellos tienen mucha más ventaja que nosotros que estamos en un mercado formal primeramente lo que es el precio un vendedor ambulante no tiene casi gastos, solo el alquiler, y el alquiler de afuera de un espacio o puesto 0 pedacitos siempre será más cómodo que pagar en un mercado, en un mercado no solo pagas el puesto, pagas luz pagas agua, pagas todo, administración, estás sujeto a muchas reglas y tienes que cumplirlas, ellos no, por eso tienden a vender la mercadería mucho más barato entre comillas, dice la gente es más baratos pero si tú te pones a pensar si es más barato, habrá que pensarlo indudablemente porque yo te puedo decir que te vendo 3 soles y te lo estoy vendiendo a 4 , uno, dos, en ellos, su desventaja para ellos creo yo es el estar afuera implica que no tienen comodidad y no pueden vender de todo, porque hay mercadería que se puede malograr en la intemperie entonces no pueden vender la milanesa y si la venden lo venden mal, porque no tienen un caño donde lavarse las manos, etc, etc, hay ventajas y desventajas, y como digo que no debe ser así, yo pienso que ellos deben no formalizar para un inicio yo creo que puede estar permitido porque no saben pero ya ellos a veces están demasiado años en la calle, 15 a 20 años?, porque están afuera, porque realmente no tienen dinero?, eso no es la verdad, realmente ellos han hecho más dinero, por eso no se formalizan, no les conviene, están acostumbrados.

\section{Entrevista 3}

\section{Adrian Paz}

Comerciante formal en el mercado San Francisco / anteriormente ambulante. ¿QUE LES HABÍA IMPEDIDO FORMALIZARSE?

Los alquileres del mercado eran caro, en la calle solo pagaban los permisos del consejo y una sisa diaria de 0.20 céntimos algo así, en cambio en un puesto formal era caro más que nada pagaba alquiler

\section{Entrevista 4}

Miguel Ángel Félix 
Presidente Actual de la Cooperativa de Servicios Especiales San Francisco Ltda.

\section{¿SABÍA QUE TRAMITES HACER O LA COOPERATIVA LOS AYUDÓ PARA HACER LOS TRÁMITES PARA FORMALIZARSE?}

Entiendo que los fundadores porque nosotros somos asociados nuevos, entiendo que los asociados y los fundadores se han sacrificado mucho no ha sido fácil, ha habido una época que donde esta parte estaba todo parametrado con el crecimiento provisional quería ocuparlo al hacerlo vivienda entonces allí con el apoyo de otro grupo importante del distrito de villa maría se pudo sostener con el asesoramiento de también de otra gente que conocía el tema del mercado, el tema de formalizar.

\section{¿PORQUE CREE USTED QUE LOS AMBULANTES NO SE FORMALIZAN?}

Pienso que ellos no quieren pagar impuestos. No quieren pagar local, falta de orientación también porque ha habido diferencias en otros distritos que le dan oportunidad e 1 a 2 años de ellos comprar su terreno y ellos pasar pero eso no ha ocurrido, la mayoría de la gente informal que tenemos alrededor son de otros distritos, no son ambulantes, son mayoristas. Vienen con camionetas llenas de verduras, lleno de fruta, triciclos llenos. Ambulantes se dice a la persona que trae un plástico y lo tira al suelo y vende contado sus cosas pero los que están alrededor nuestro en la avenida san José, y en la avenida Olaya son mayoristas.

\section{Entrevista 5}

Pedro Vilchez

Representante de Gerencia de Desarrollo Económico Local de la Municipalidad de Villa María del Triunfo.

\section{USTEDES QUE VEN CADA DIA LA INFORMALIDAD, ¿CUAL PIENSA QUE ES}

\section{LA RAZÓN POR LA QUE SE NIEGA LA GENTE A FORMALIZARSE?}

Bueno hay muchas razones, una de ellas es la falta de recursos no, su propio modo de vida, de hacer las cosas, digamos como empíricamente y también la falta de decisión a veces de las autoridades que no toman las riendas para poder encontrar este problema que tienen algunos distritos. 


\section{¿ESTA GESTIÓN QUÉ MEDIDAS ESTÁ TOMANDO CON RESPECTO A LOS} AMBULANTES INFORMALES?

Estamos trabajando ahorita, en la elaboración de un proyecto de ordenanza que pretende ordenar y formalizar todo el comercio ambulatorio en todo villa maría del triunfo, tenemos una ordenanza del 2008 que ya está desfasada podríamos decirlo y no cumple con las expectativas que tiene la ciudad, la ciudad ha crecido demasiado $y$ ha crecido de una forma desordenada y ahorita estamos justo trabajando en un proyecto de ordenanza para poder encauzar y establecer unas zonas rígidas, algunas zonas rígidas para que esto no se desarrolle de una manera desordenada.

\section{¿QUE TANTO AFECTA EL TRABAJO AMBULATORIO PARA UNA MEJORA DEL DISTRITO?}

En qué afecta el trabajo ambulatorio, el trabajo ambulatorio afecta mucho al comerciante formal, si ustedes saben en todos los distritos hay negocios que cuentan licencia de funcionamiento, pagan sus impuestos, pagan todos sus servicios, mientras que el comercio ambulatorio no, esto merma en ingreso al comercio formal.

\section{¿AL DISTRITO?}

Cómo afecta, nos genera desorden, nos genera residuos sólidos, incrementa la basura y la municipalidad deja de percibir ingresos por parte de ellos, lo que la municipalidad trata de promover, para mejorar esto, es que estos comerciantes en un pequeño a corto plazo puedan volverse formales y luego a lo largo tener un negocio propio en un establecimiento con las licencias de funcionamiento con certificado de fuerza civil y que ya no estén en la vía pública.

\section{¿EL DINERO QUE USTEDES RECAUDAN DE LOS TRIBUTOS COMERCIALES A DONDE ESTÁN DESTINADOS EXACTAMENTE?}

He bueno eso se destina a distintas formas, se destina para pago de personal, para servicios, servicios básicos, luz agua teléfono, para combustibles de las maquinarias y diversas cosas, también se destinan para las obras del distrito, las obras que están programadas.

\section{¿QUÉ PIENSA USTED DEL HECHO QUE LOS COMERCIANTES INFORMALES, EVADAN SUS TRIBUTOS?}


Como le dije en la pregunta anterior esto perjudica al distrito, porque deja de recaudar impuestos, y los impuestos para poder brindar un mejor servicio a la población, nosotros dejamos de recibir impuestos, dejamos de dar nuestro servicios a la población, eso sería el inconveniente.

\section{¿QUÉ PODEMOS HACER LOS CIUDADANOS CON RESPECTO A LOS}

\section{AMBULANTES?}

Generalmente lo que se recomienda es ir o solicitar un servicio de manera formal, siempre preferimos que vaya a un mercado, que vayan a las tiendas, pero lamentablemente el comercio ambulatorio, digamos que es la solución al problema diario de la misma población, que sugeriría, que evitemos consumir tanto comercio ambulatorio, que consumimos más, comercio formal.

\section{¿QUÉ PIENSA USTED PORQUE LOS AMBULANTES NO SE FORMALIZAN?}

Porque es un medio de trabajo rápido y fácil, mucha gente agarra sus productos o lo que tiene a la mano y sale y lo vende a la esquina de su casa, ese proceso de formalización es un trabajo que nos compete a nosotros, darle la capacitación, darle la orientación, darle las recomendaciones, mucha gente sale y por la misma necesidad empieza a vender lo que se le ocurre de alguna manera improvisada.

\section{¿EL SISA AÚN SE SIGUE COBRANDO?}

No, actualmente no, estamos justo haciendo la evaluación de todo eso, el sisa se cobraba 1 sol diario, actualmente justo estamos actualizando esta currícula, que está complicado en el distrito de villa María, 7000 ambulantes es bastante, imagínese quitar el puesto de trabajo a 7000 personas. ahorita, un dolor de cabeza, así que es un trabajo que se tiene que trabajar con mucho cuidado.

\section{¿PUEDEN VENDER DIVERSOS PRODUCTOS?}

Eso también está establecido en la ordenanza, nosotros trabajamos esta ordenanza en base de lo que dice Lima Metropolitana y Lima Metropolitana establece giros para el comercio ambulatorio, por eso les hablaba del comercio ambulatorio modulado, que entra allí, anticucho, picarones, mollejas, todos los derivados de estos, llaves, cerrajerías, artesanías, también es otro de los rubros, lustrabotas, desayunos, emolienteros, que ellos tienen su propia ley y los canillitas y los que venden periódico. 
Hay rubros que no son considerados como comercio ambulatorio, hay cosas que si se van a tener que erradicar definitivamente. 


\section{CAPÍTULO V}

\subsection{Análisis del Diseño en general}

\subsubsection{Sintaxis}

\section{Logo}

El logo ha sido construido con lettering y tipografía, las características que se usó para escribir la expresión fue de las letras gruesas y redondeadas al igual que la descripción inferior pero con distintos estilos, los colores vivaces que se escogió y el lenguaje coloquial de la expresión utilizada, se tomó de la cultura popular peruana.

El lettering usado está inspirado en el estilo chicha que tienen los murales del letrista Elliot Tupac. La frase que se utiliza, "Vamos pa' lante" es una expresión que se utiliza para animar a seguir adelante a una persona. Para complementar el logo se puso una corta descripción en la parte inferior que dice "compra responsable", el punto principal de la campaña es la concientización de los compradores para que hagan sus compras en lugares formales que estén dentro de las leyes.

A los colores seleccionado, se les aplicó un degradado de arriba hacia abajo comenzando del fucsia, naranja y terminando con verde, todo el lettering tiene una perspectiva unificada de un tono azul haciendo así resaltar mucho más los colores vibrantes del degradado y dándole profundidad al logo.

\section{Lettering y Tipografía}

El lettering que se realizó para el logo fue hecha únicamente para el proyecto y para la descripción inferior se utilizó la tipografía "cocogoose"

La posición de cómo se creó el lettering, es importante ya que va de forma ascendente tanto la expresión como la descripción, ya que connota el emprendimiento y superación de parte de los comerciantes y el distrito mismo.

\section{Color}

Los colores principales que se encuentran en el lettering, se escogieron, ya que el público objetivo al que se está dirigido el proyecto es a una cultura popular, también la elección de estos colores se relaciones a la motivación y esperanza en mejorar su estilo de vida.

\section{Tótem de exposición de fotografía}


La pieza principal del proyecto es el tótem de exposición fotográfica, las dimensiones de la base son de $1,50 \mathrm{~cm}$ de altura, $60 \mathrm{~cm}$ de ancho y $40 \mathrm{~cm}$ de profundidad, la forma del tótem es de una cartera de mercado la cual usualmente se lleva en estos mercados comerciales, se hicieron dos para distintos puntos del mercado.

A los lados más anchos de la estructura se pusieron 6 fotografías por lado, fueron editadas para resaltar los problemas de infraestructura del distrito con la gama de colores que se eligió para el logo y toda la línea grafica de la campaña.

\subsubsection{Estética}

La estética que se eligió para el proyecto, fue inspirada en de la cultura popular que se encuentra en la zona, ya que los colores son vibrantes y del estilo chicha.

\subsubsection{Simbología}

El haber elegido construir carteras a gran escala y con colores vibrantes, fue para llamar la atención al público objetivo, ya que por ser mujeres y madres están ocupadas o atareadas con sus compras y la idea era tomar de ese momento de distracción su atención ya que es poco usual ver ese tipo de estructuras en este mercado.

\subsubsection{Pragmatismo}

El proyecto busca por medio de fotografías concientizar hacer una compra responsable de los clientes e ir a comerciantes formales, ya que así se estaría ayudando a la mejora del distrito.

Por medio de los colores, y grandes estructuras se quiere que haya un gran impacto así como es el problema que se está tratando.

\subsection{Diseño de la Comunicación}

\subsubsection{Fundamentación del diseño}

La estructura del proyecto consistió en la construcción de dos tótems de un objeto usual que se lleva al mercado a gran escala con fotografías puestas en esta, como método de comunicación son las fotografías de gran impacto para concientizar a los clientes sobre las consecuencias que tiene el comprar a comerciantes ambulatorios. El apoyo visual se está utilizando como impacto hacia el público 
objetivo, se refuerza la experiencia con la línea gráfica que se eligió de la cultura popular, para llamar la atención al espectador.

Finalmente, este proyecto quiere comunicarse de forma visual y que llegue a los clientes frecuentes del mercado.

\section{Paleta de color}
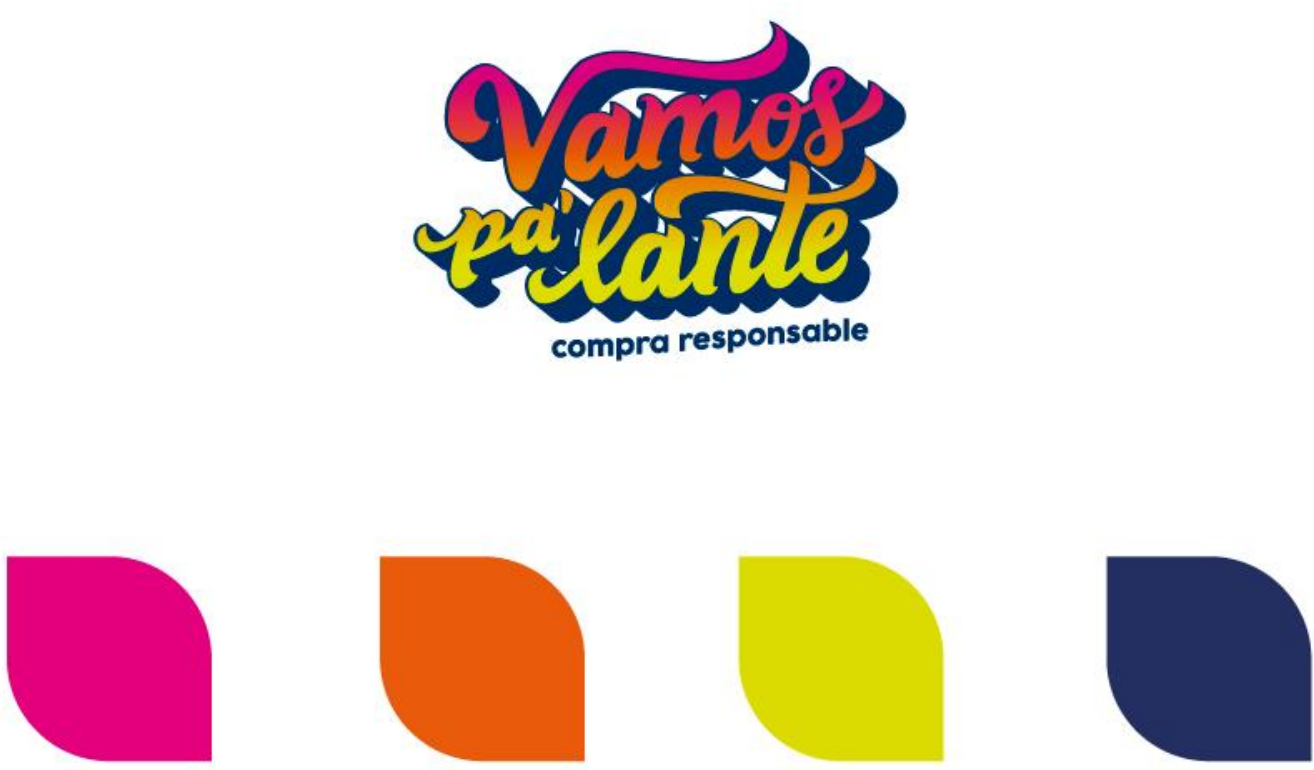
C: 0
M:O
Y: 0
K: 100

C: 0

M: 75

Y: 100

K: 0

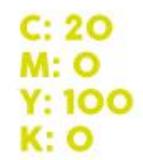

C: 100

M: 90

Y: 30

K: 20

Figura 5. Paleta de color

\subsubsection{Propuesta gráfica}

Anteriormente, se comentó que la línea gráfica seria a base de la cultura popular chicha, ya que el tono de comunicación del proyecto que se tomo es amigable y colorido para un tema denso como son los problemas que tiene Villa María del Triunfo, por la falta de pagos de impuestos que los comerciante informales no contribuyen al distrito 


\section{Piezas Gráficas}

a. Tótem
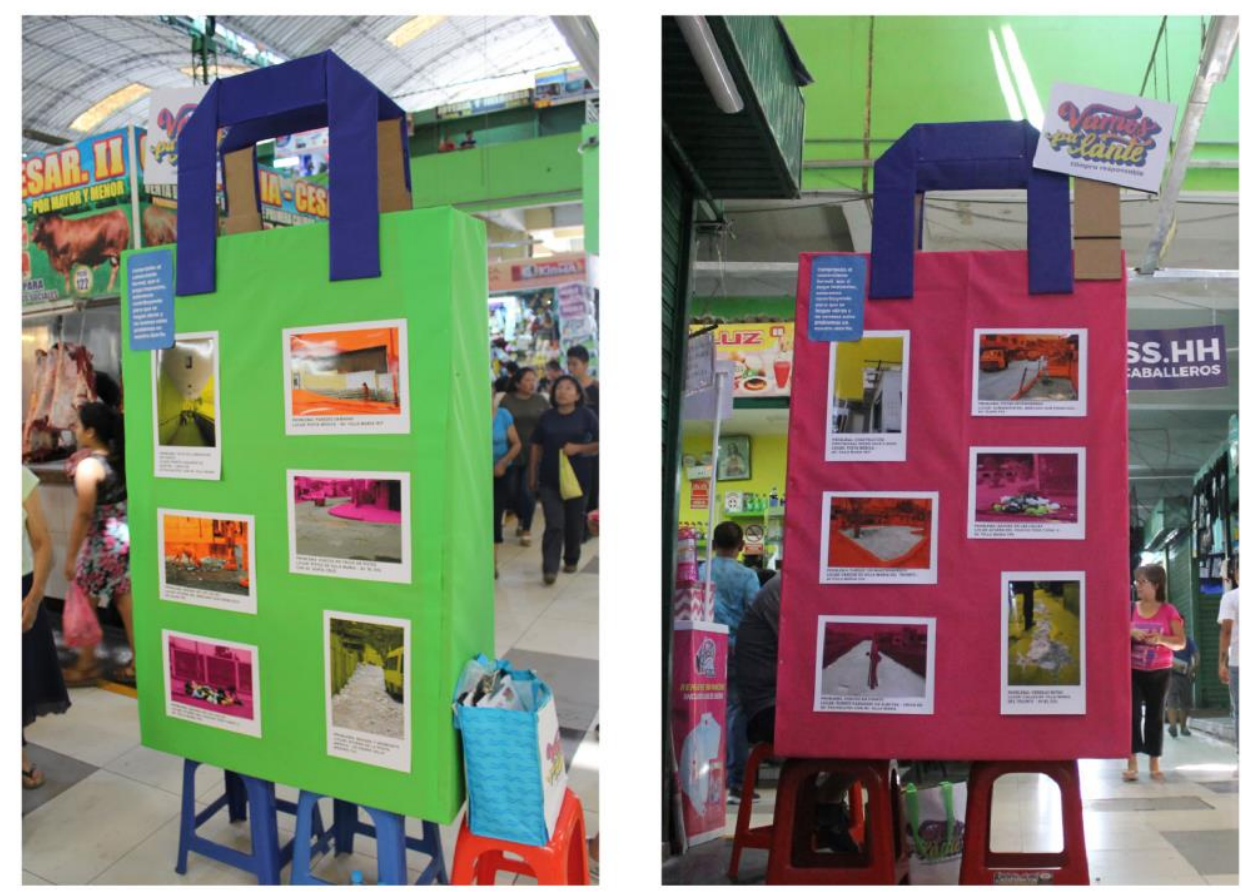

Figura 6. Totems de exposición fotograficafotográficos

b. Polos
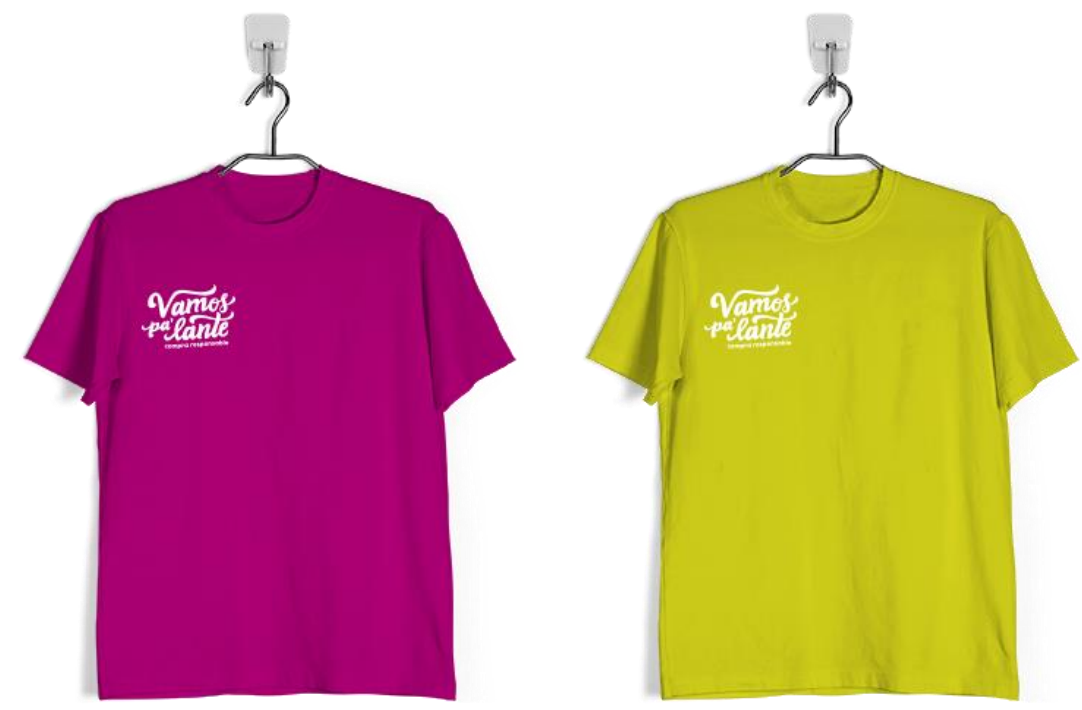

Figura 7. Polos de Staff

c. Folletos informativos 

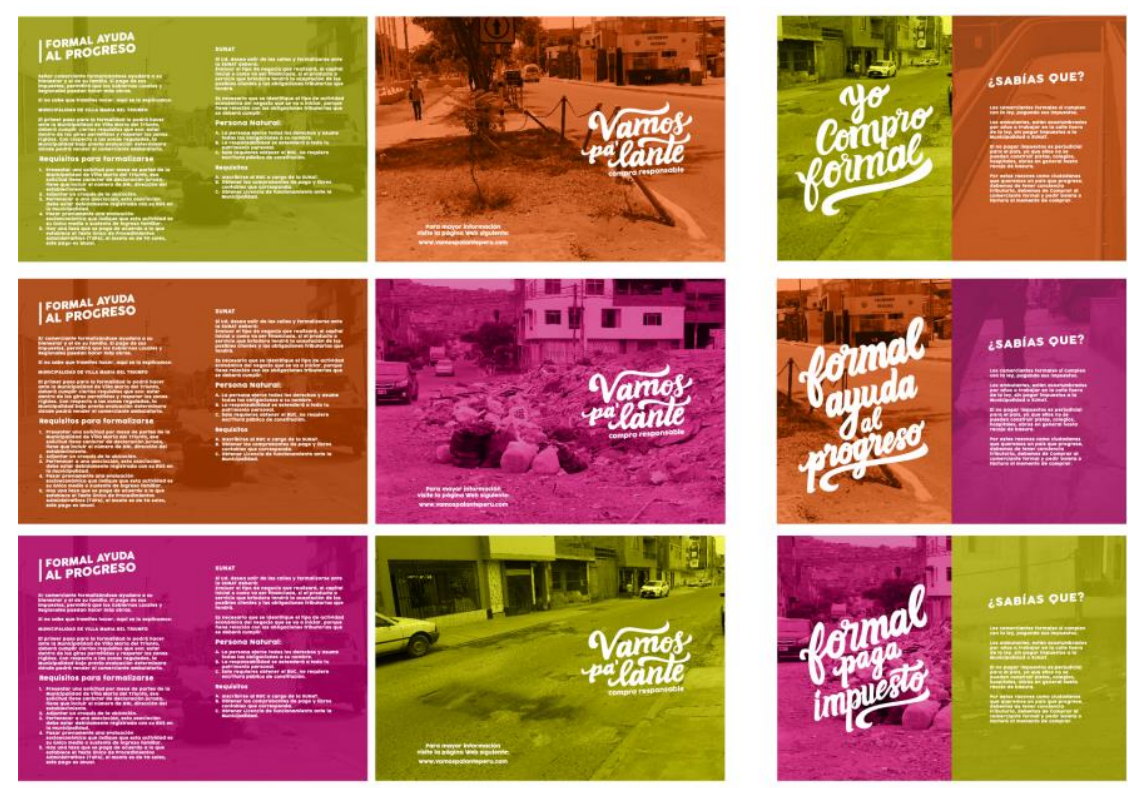

Figura 8. Folletos Informativos

d. Encuestas
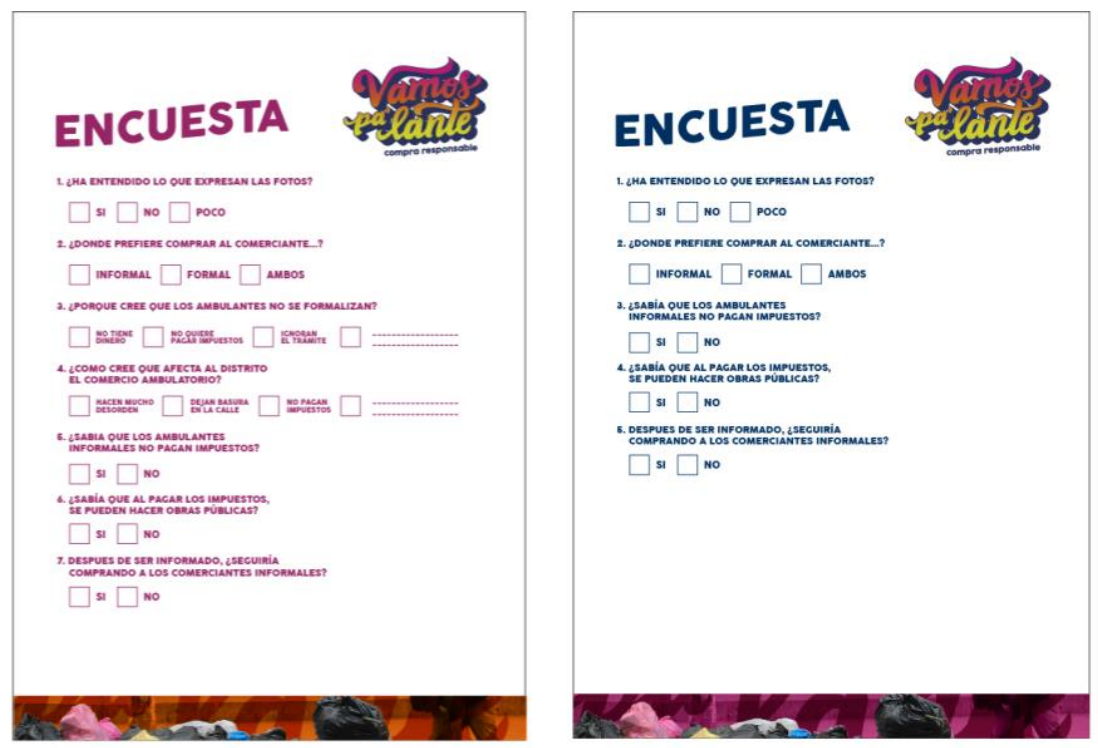

Figura 9. Encuestas

e. Obsequios (libreta + lapicero)
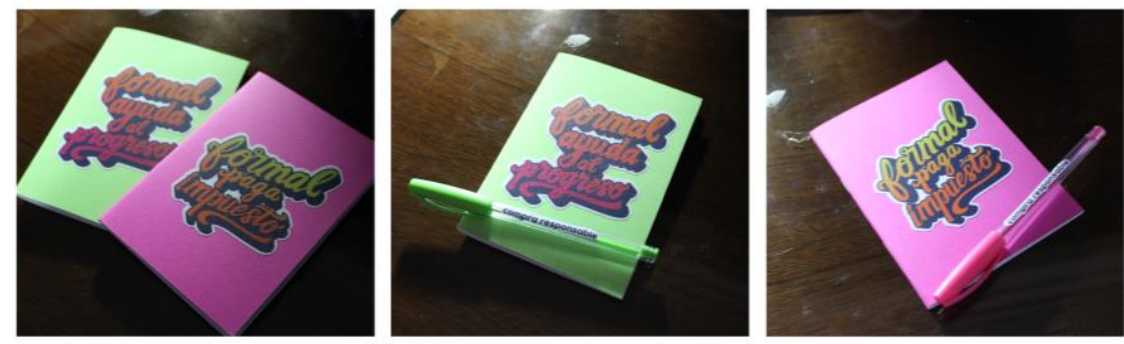

Figura 10. Libretas y Lapiceros 
f. Fan Page

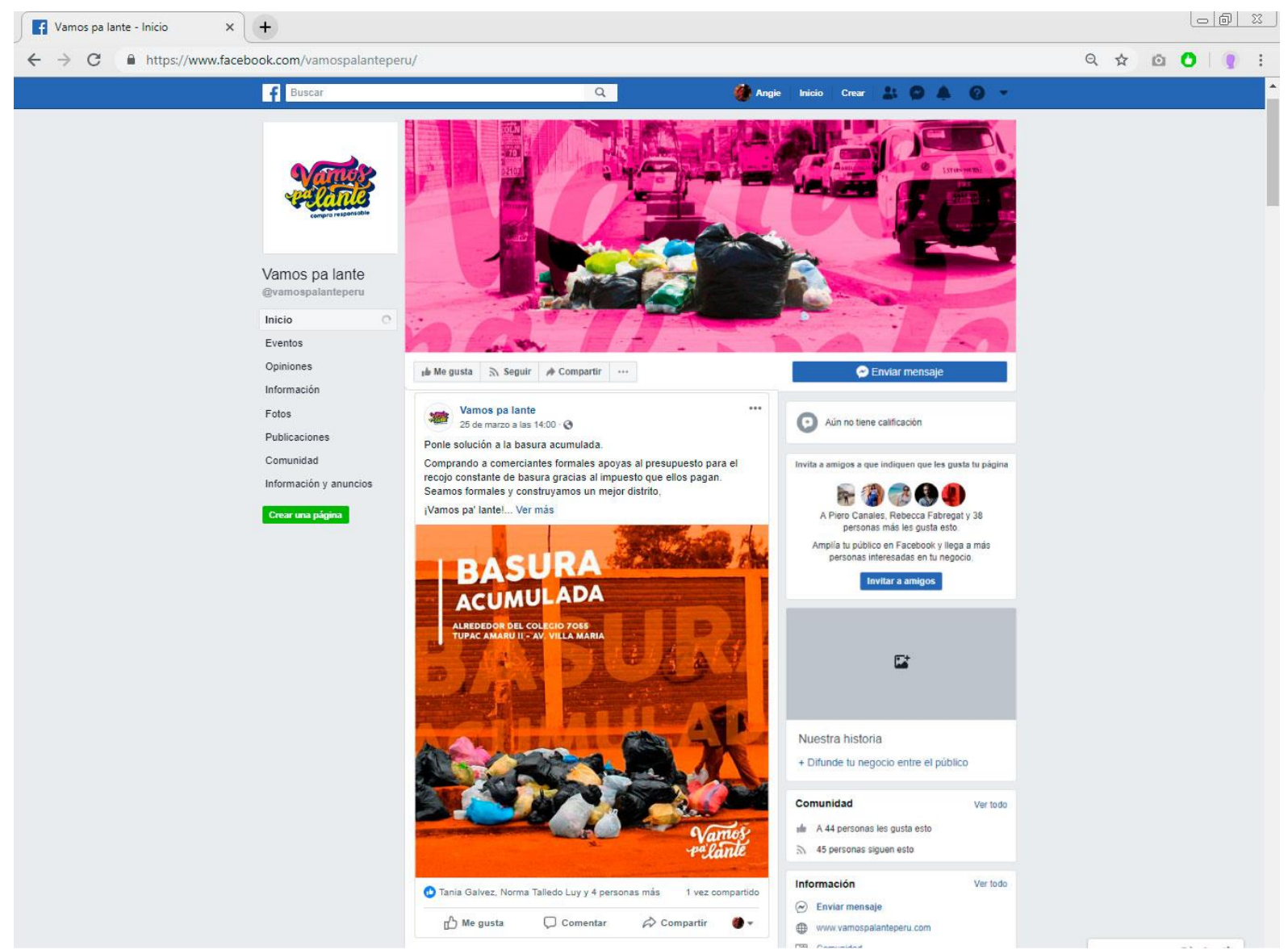

Figura 11. Página de Facebook

g. Página Web
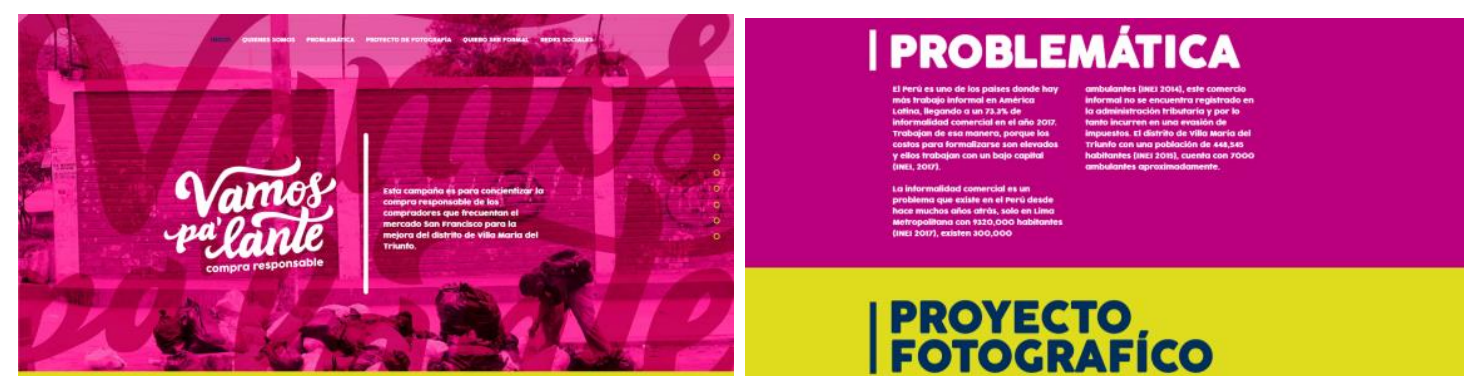

| OOUIENES

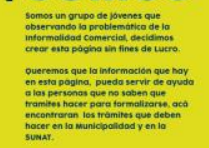

I PROBLEMÁTICA

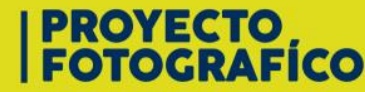

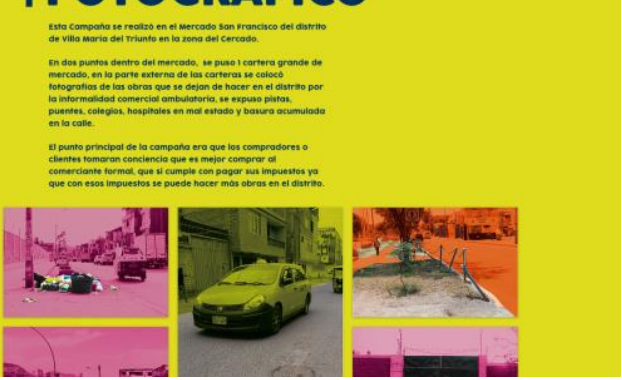

Figura 12. Página web 


\subsubsection{Etapas del proyecto}

\section{Etapa 1: Desarrollo de comunicación}

Objetivo: Concientizar a los compradores, hacerles ver que el que ellos hagan compras responsables en local autorizado y dentro de las reglas, ayudan a la mejora del distrito, porque esos comerciantes que tienen un puesto fijo en un establecimiento pagan impuestos, y estos tributos están dirigidos para la mejora de infraestructuras y servicios que brinda los Gobiernos Locales y Regionales. Estarán los de Staff para cualquier duda de los espectadores y para realizar las encuestas. Actividad: Exposición de fotografía en base de tótems, se les hará encuestas a las personas que observen la exposición y se le dará un pequeño obsequio por su participación con su respectivo volante para el comprador.

Actividad 2: Entrega de volantes a los comerciantes ambulantes con información de los pasos para formalizarse.

Material: Polos, tótems, encuestas, trípticos y volantes, obsequio.

\section{Etapa 2: Mantenimiento}

Objetivo: Seguir reforzando lo que se presentó en la campaña en plataforma digital Actividades: Publicar en las redes sociales fotografías de la campaña, post de los problemas presentados, post de información de formalización para los comerciantes, publicar la página donde se encuentra la información completa.

Material: Redes sociales, página web y fotografías. 


\section{CAPITULO VI}

\subsection{Análisis de los resultados}

\section{Aplicación}

La exposición fotográfica, se pudo llevar a cabo dentro del mercado San Francisco en el distrito de Villa María del Triunfo, gracias al apoyo de la parte administrativa de la cooperativa del mercado que dieron el permiso y la ayuda necesaria, también nos brindaron apoyo de seguridad dentro de las instalaciones ante cualquier eventualidad.

La campaña se hizo en una sola etapa, se realizó el domingo 17 de marzo, se movilizaron 2 carteras de mercado a gran escala con letreros de la campaña a dos puntos dentro del mercado, en las carteras estaban pegadas fotografías resaltando por medio de colores vivos los problemas de infraestructura y servicios que tiene actualmente Villa María del triunfo, como parques fuera de mantenimiento, recojo de basura, pistas, veredas y puentes en mal estado entre otros.

Luego que las personas se quedaran observando la exposición fotográfica, se le abordo, para hacerle una corta encuesta sobre lo que acababan de observar y saber su opinión de este problema, al finalizar se le dio un volante informativo de la campaña y un pequeño presente por su opinión.

Luego de haber hecho la encuesta a 42 personas dentro del mercado, se hizo un volanteo en la parte externa del mercado, se entregó un volante informativo a los ambulantes con los pasos para formalizarse, se colocó también en el volante la página web para mayor información.

\subsection{Diseño de la metodología}

\section{Etapa 1: Licencias y preparación}

- Pedir permisos a la cooperativa para realizar campaña dentro de las instalaciones del mercado

- Diseñar las piezas de comunicación visual: tótems en forma de cartera gigante, flyers informativos, encuestas, polos de staff, fan page, pagina web y obsequios.

\section{Etapa 2: Comunicación}

- Se pusieron 2 tótems en forma de cartera de mercado y en las caras más anchas de cada una de las carteras, se colocó fotografías 
exponiendo los problemas de infraestructura y servicios que tiene el distrito de Villa María.

- El público objetivo se acercó para observar las fotos y las dos personas del staff de cada una de los puntos se encargaron de aclarar cualquier duda sobre el tema, asimismo estuvieron haciendo las encuestas para saber su opinión sobre el tema luego entregaron un volante informativo y un presente relacionado con la campaña.

- Finalizando la campaña se dieron flyer informativos a los comerciantes informales que estaban en los exteriores del mercado. Dándoles la información de cómo formalizarse ante las autoridades.

\section{Etapa 3: Resultados}

- Las encuestas demostraron que se cambió en un $11.4 \%$ la opinión de los compradores, de comprar a compradores informales para comprar a compradores formales.

- Se hizo la pregunta de porque cree que los ambulantes no se formalizan, la mayoría de los encuestados comento porque no quieren pagar impuestos con un $62.5 \%$, no tienen dinero en un $25 \%$ e ignoran el trámite en un $12.5 \%$.

\subsection{Evaluación de la metodología}

La metodología que se aplicó en la implementación impacto al público y fue efectiva ya que no es usual ver algo así en esta zona, ayudo los colores chillantes que se utilizaron, la comunicación visual que se utilizó ayudo a cumplir el objetivo de dar a conocer la falta de desarrollo que tiene Villa María por la falta de pago de impuestos por parte de los comerciantes informales. Fue más impactante de lo que se tenía previsto y falto más staff para abarcar a todas las personas que tenían dudas y quería consultar sobre la campaña.

El lugar donde se ubicaron los tótems, fue estratégico y ayudo a la hora de poder recaudar información por medio de las encuestas hechas y lo comentarios que nos daban los compradores. 


\subsection{Registro de la implementación}
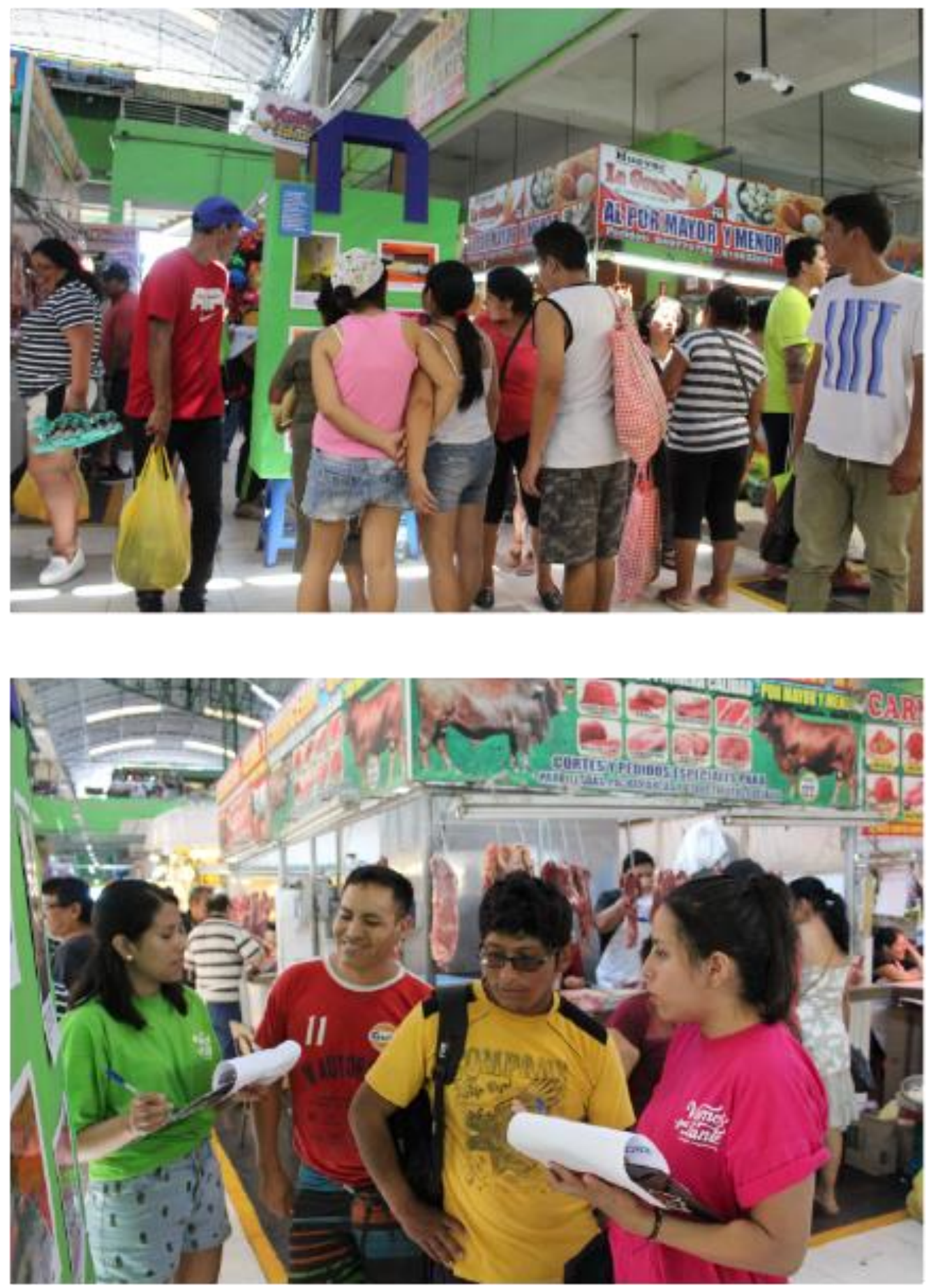

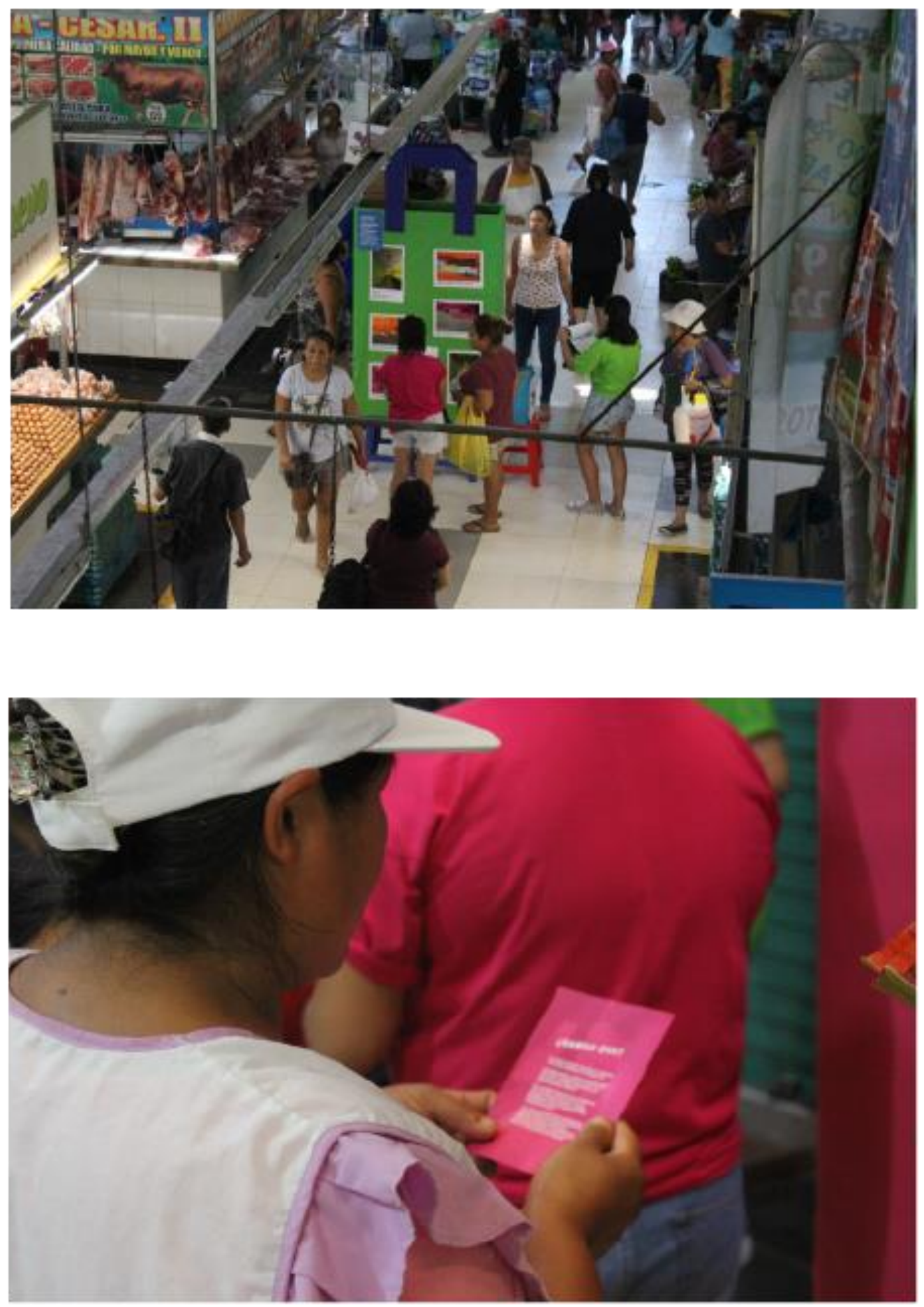

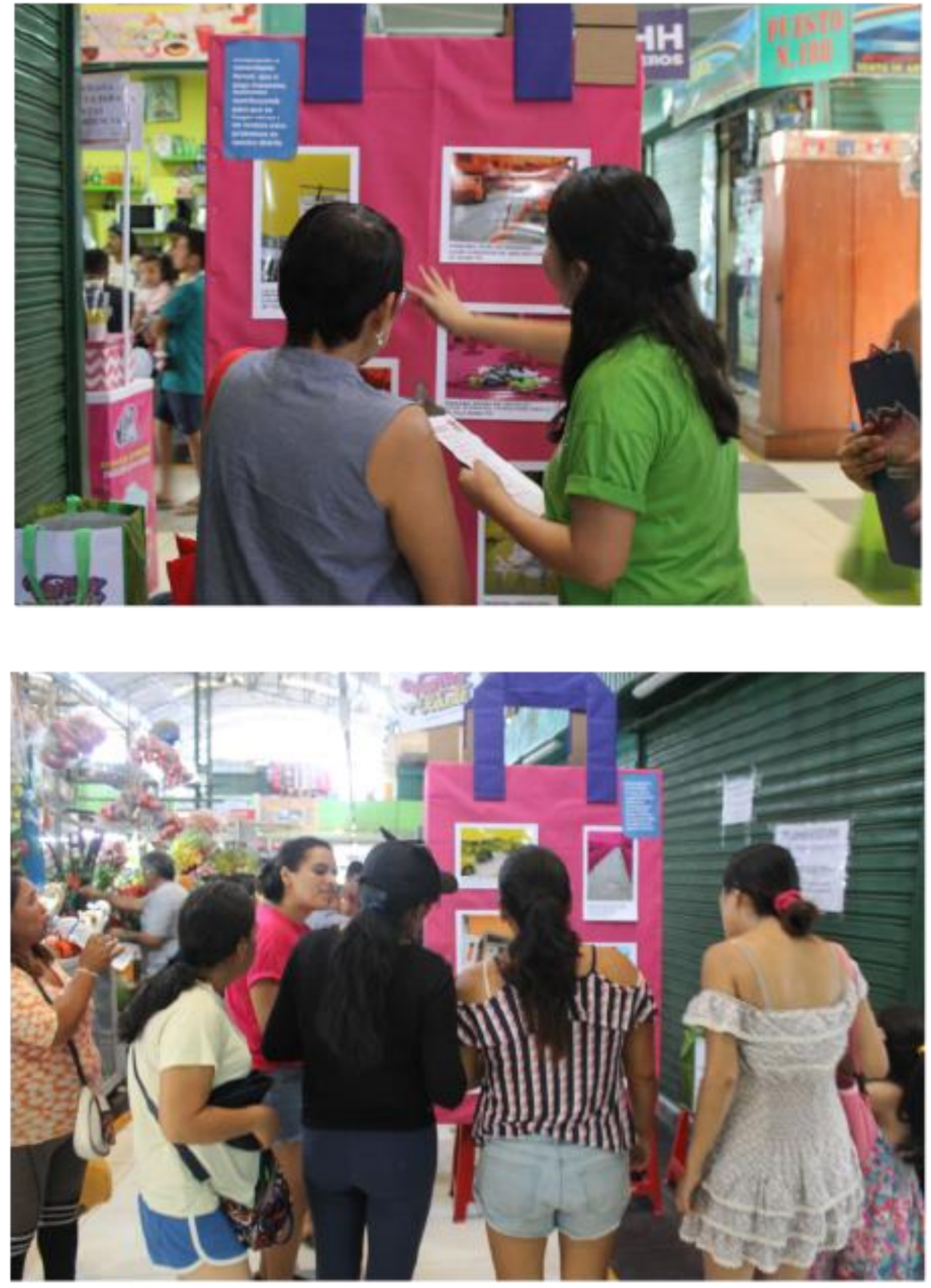

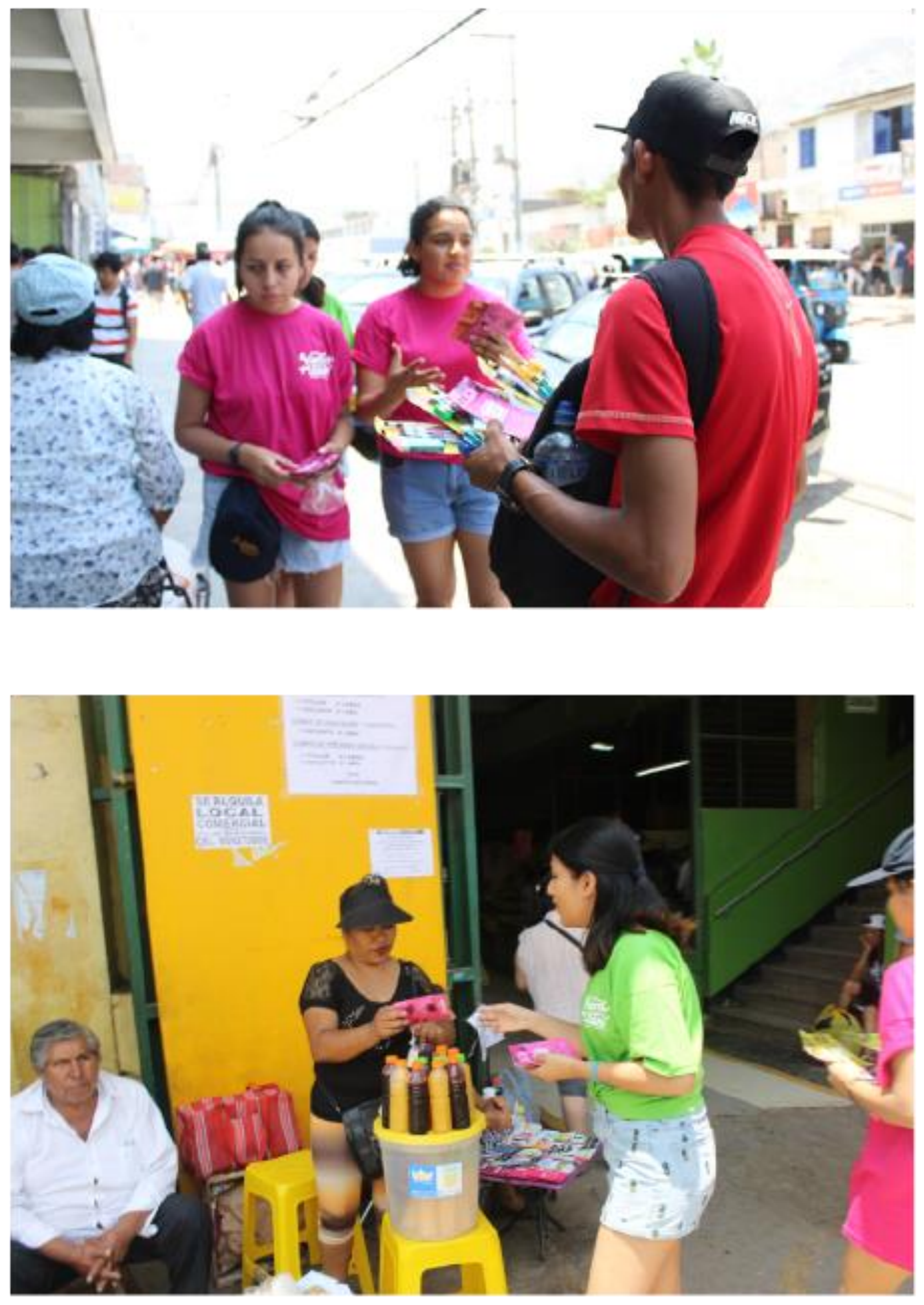


\subsection{Documentos que acrediten evaluación de par}

Lima, 28 de Marzo del 2019

A quien corresponda

Presente.-

Yo, Annie Blanca Vargas Carrión, identificado con D.N.I. 73864898 licenciada en Arte y Diseño Empresarial por la Universidad San Ignacio de Loyola. Acredito por medio de este documento que el Proyecto "Vamos pa' lante" del bachiller Angie Antonella Sardá Talledo, identificado con D.N.I. 735376969, cumple con el objetivo de concientización de los compradores que viven en la zona especificada del distrito de Villa María del Triunfo y que frecuentan el mercado San Francisco, mostrando que comprar a ambulantes, afecta a la mejora del distrito. Por medio de una exposición fotográfica en tótems en forma de carteras gigantes como estrategia de comunicación para los compradores, se expusieron los problemas de infraestructura pública que tiene el distrito, haciendo ver que ellos mismos pueden hacer un cambio en la situación actual del distrito, comprando a comerciantes formales que si pagan impuestos para que se puedan hacer mas obras.

Expido el siguiente documento para los fines que ella considere conveniente.

Annie Blañca Vargas Carrión
Licenciadá en Arte y Diseño Empresarial 
Lima, 31 de Marzo del 2019

\section{A quien corresponda \\ Presente.-}

Yo, Kiara Antuanet Guzmán Talledo, identificado con D.N.I. 73108115 licenciada en Ciencias de la Comunicación por la Universidad San Martin de Porres. Acredito por medio de este documento que el Proyecto "Vamos pa' lante" del bachiller Angie Antonella Sarda Talledo, identificado con D.N.I. 735376969 , cumple con el objetivo de concientización de los compradores que viven en la zona especificada del distrito de Villa Maria del Triunfo y que frecuentan el mercado San Francisco, mostrando que comprar a ambulantes, afecta a la mejora del distrito. Por medio de una exposición fotográfica en tótems en forma de carteras gigantes como estrategia de comunicacićn para los compradores, se expusieron los problemas de infraestructura pública que tiene el distrito, haciendo ver que ellos mismos pueden hacer un cambio en la situación actual del distrito, comprando a comerciantes formales que si pagan impuestos para que se puedan hacer mas obras.

Expido el siguiente documento para los fines que ella considere conveniente.<smiles>CCCCNC(C)C</smiles>

Kiara Antuanet Guzmán Taliedo Licenciado en Ciencias de la Comunicación 
Lima, 29 de Marzo del 2019

\section{A quien corresponda \\ Presente.-}

Yo, Ximena Alexandra Jimenez Paredes identificado con D.N.I. 73808702 licenciada en Arte y Diseño Empresarial por la Universidad San Ignacio de Loyola.

Acredito por medio de este documento que el Proyecto "Vamos pa' lante" del bachiller Angie Antonella Sardá Talledo, identificado con D.N.I. 735376969 , cumple con el objetivo de concientización de los compradores que viven en la zona especificada del distrito de Villa María del Triunfo y que frecuentan el mercado San Francisco, mostrando que comprar a ambulantes, afecta a la mejora del distrito. Por medio de una exposición fotográfica en tótems en forma de carteras gigantes como estrategia de comunicación para los compradores, se expusieron los problemas de infraestructura pública que tiene el distrito, haciendo ver que ellos mismos pueden hacer un cambio en la situación actual del distrito, comprando a comerciantes formales que si pagan impuestos para que se puedan hacer mas obras.

Expido el siguiente documento para los fines que ella considere conveniente.

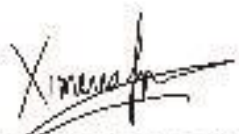

Ximena Alexandra Jimenez Paredes

Licenciada en Arte y Diseño Empresarial 
Lima, 29 de Marzo del 2019

\section{A quien corresponda}

Presente.-

Yo, Brian Antonio Giraldez Linares identificado con D.N.I. 71701175 licenciado en Arte y Diseño Empresarial por la Universidad San Ignacio de Loyola.

Acredito por medio de este documento que el Proyecto "Vamos pa' lante" del bachiller Angie Antonella Sardá Talledo, identificado con D.N.I. 735376969 , cumple con el objetivo de concientización de los compradores que viven en la zona especificada del distrito de Villa María del Triunfo y que frecuentan el mercado San Francisco, mostrando que comprar a ambulantes, afecta a la mejora del distrito. Por medio de una exposición fotográfica en tótems en forma de carteras gigantes como estrategia de comunicación para los compradores, se expusieron los problemas de infraestructura pública que tiene el distrito, haciendo ver que ellos mismos pueden hacer un cambio en la situación actual del distrito, comprando a comerciantes formales que si pagan impuestos para que se puedan hacer mas obras.

Expido el siguiente documento para los fines que ella considere conveniente.

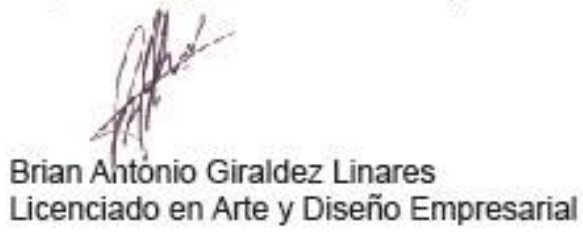


Lima, 2 de abril del 2019

\section{A quien corresponda}

\section{Presente.}

Yo Juan Pablo Miguel Aponte Ruidias identificado con D.N.I. 42806782 licenciado en Diseño y Gestión de Marca por la Universidad San Ignacio do Loyola. Acredito por medio de este documento que el Proyecto "Vamos pa' lante" del bachiller Angie Antonella Sardá Talledo, identificado con D.N.I. 735376969. cumple con el objetivo de concientización de los compradores que viven en la zona especificada del distrito de Villa Maria del Triunfo y que frecuentan el mercado San Francisco, mostrando que comprar a ambulantes, afecta a la mejora del distrito. Por medio de una exposición fotográfica en tótems en forma de carteras gigantes como estrategia de comunicación para los compradores, se expusieron los problemas de infraestructura pública que tiene el distrito, haciendo ver que ellos mismos pueden hacer un cambio en lá situación actual del distrito, comprando a comerciantes formales que si pagan impuestos para que se puedan hacer mas obras.

Expido el siguiente documento para los fines que ella considere conveniente.

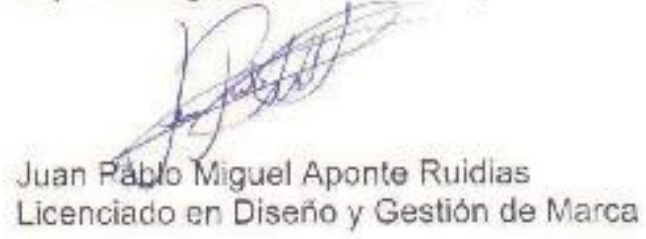




\section{CAPÍTULO VII}

\subsection{Conclusiones}

- La línea grafica que se utilizó fue capaz de aligerar un tema denso como es la realización de trámites, entender ordenanzas y leyes que se presenta a la hora de formalizarse ante la municipalidad y la SUNAT para poder estar informados.

- Explicar de una forma coloquial a la hora de comunicación, tanto hablada como escrita, hacia los compradores como a los comerciantes informales fue efectiva.

- La comunicación visual que se utilizó, ayudo a la concientización de los compradores, ya que tiene mucho mayor impacto.

- El uso de volantes informativos en un lenguaje coloquial, ayudo a informar más a las personas interesadas en la campaña, para que no tuvieran dificultad de entenderlo.

\subsection{Recomendaciones}

- Si se dan a conocer a las personas, las construcciones y servicios que se dejan de hacer por la falta de impuestos, también se deberían dar a conocer las nuevas mejoras que tendrá el distrito por el pago de estos, para que los compradores y comerciantes vean que lo que ellos aportan está generando un beneficio para el lugar donde viven.

- Hacer un estudio de campo de los compradores y comerciantes informales, para saber cuáles son los problemas actuales que se están produciendo en el distrito y buscar soluciones que sea beneficioso para ambas partes.

- Tener espacios donde los comerciantes informales puedan ubicarse hasta que puedan tener mayor capital para formalizarse.

- Dar más oportunidades de trabajo, enfocándose en los comerciantes informales y que sean remuneradas correctamente. 


\begin{abstract}
ANEXOS
A continuación se señalan algunas normativas relacionadas al sector:

CONSTITUCIÓN POLÍTICA DEL PERÚ (1993)

ARTíCULO № 2: Toda persona tiene Derecho: Numeral 1.- A la vida, a su identidad, a su integridad moral, psíquica y física y a su libre desarrollo y bienestar. El concebido es sujeto de Derecho en todo cuanto la favorezca.

Numeral 15. A trabajar libremente, con sujeción a ley.

ARTíCULO $\mathbf{N}^{\circ} \mathbf{2 2}^{\circ}$. El trabajo es un deber y un derecho. Es base del bienestar social y un medio de realización de la persona.

DECRETO SUPREMO № 005-91-TR (26/01/91) Reconocen Al Trabajador Ambulante La Calidad Jurídica De Trabajador Autónomo Ambulatorio.- En este Decreto Supremo No 005-91.TR se reconoce la calidad jurídica de trabajador autónomo ambulatorio al trabajador ambulante, al ser esta actividad producto de un contexto de crisis económica y una respuesta al desempleo y subempleo en que se encuentra la población. Sin embargo, en dicho decreto supremo se señala una ley de comercio ambulatorio que debería ser promulgada, la cual a la fecha no existe, lo que dificulta normar sobre este sector.
\end{abstract}

\title{
Ordenanza Municipal
}

\section{ORDENANZA No 049-2008/MVMT}

14 de marzo del 2008 El artículo 194 de la Constitución Política del Estado, modificada por la Ley de Reforma Constitucional, Ley No 27680 , establece que las Municipalidades Provinciales y Distritales son gobiernos locales con autonomía política, económica y administrativa en los asuntos de su competencia; Que, el Artículo $83^{\circ}$, inc.3) acápite 2 de la Ley Orgánica de Municipalidades № 27972 , establece que son funciones específicas exclusivas de las Municipalidades Distritales, en materia de abastecimiento y comercialización de productos y servicios regular y controlar el comercio ambulatorio, de acuerdo a las normas establecidas por la Municipalidad Provincial;

ORDENANZA SOBRE ORDENAMIENTO DEL COMERCIO AMBULATORIO Y REGLAMENTA LA ADMINISTRACIÓN DEL COMERCIO EN LA VÍA PÚBLICA DEL DISTRITO DE VILLA MARÍA DEL TRIUNFO 
Artículo Primero.- La presente ordenanza tiene por objeto establecer los procedimientos, políticas y lineamientos para llevar a cabo el ordenamiento gradual y progresivo del Comercio ambulatorio y/o informal dentro de la jurisdicción del Distrito de Villa María del Triunfo, a fin de velar por la seguridad y tranquilidad de los vecinos. El ordenamiento gradual y progresivo antes referido, comprende las acciones que ejecutará la Municipalidad Distrital, con el apoyo de las instituciones Públicas y Privadas cuyas funciones o actividades tengan relación directa o indirecta con la recuperación del Distrito. Asimismo, se convocará a las personas naturales y/o jurídicas que tengan interés en participar en estas acciones.

Artículo Segundo.- Las acciones a realizarse dentro del ordenamiento gradual y progresivo del comercio ambulatorio y/o informal son las siguientes:

a) Desplazamiento fuera de la zona de Ordenamiento Urbano de los Comerciantes Ambulantes y/o Informales no autorizados por la Municipalidad Distrital de Villa María del Triunfo.

b) Modularización obligatoria de los comerciantes ambulantes autorizados siempre que desarrollen actividades compatibles de acuerdo a lo que disponga la Municipalidad.

NORMAS LEGALES El Peruano 19 de marzo de 2008369117

c) Los comerciantes ambulantes y/o informales excedentes a que se refiere el literal a) se ubicarán en inmuebles, locales o terrenos autofinanciados por ellos mismos, con orientación y apoyo técnico de la Municipalidad Distrital.

d) Mantenimiento del orden establecido en cuanto a las acciones a que se refieren los literales a), b), c) del presente artículo.

e) Ejecución de obras de recuperación, restauración, rehabilitación, revalorización, preservación y/o conservación según el caso.

f) Establecer acciones de asesoría y apoyo para que los comerciantes ambulantes e informales abandonen la vía pública, se establezcan en locales y continúen desarrollando su actividad comercial.

g) Establecer facilidades e incentivos así como acciones de promoción empresarial que contribuyan al progreso y desarrollo del comercio ambulatorio e informal. 
h) Dictar medidas necesarias a fin de facilitar la transición comercial de este grupo de personas, que van desde un tratamiento tributario especial de carácter temporal hasta un servicio de asesoría y capacitación para la inserción laboral o la generación de iniciativas empresariales.

i) Creación de condiciones apropiadas para fortalecer capacidades y promover procesos para la formalización, y optar por proyectos formales y definitivos.

Artículo Tercero.- Están comprendidos dentro del ordenamiento dispuesto mediante la presente Ordenanza todos los comerciantes que ocupen la vía pública del distrito, debiendo iniciar los procesos de formalización y gestión comercial que requieran, permitiendo recuperar los espacios públicos para los ciudadanos del distrito.

Artículo Cuarto.- La Municipalidad de Villa María del Triunfo a través de la Gerencia de Desarrollo Económico, aplicará los alcances del presente reglamento, coordinará con los órganos desconcentrados a fin de garantizar el ordenamiento y control del comercio en la vía pública en el área que le corresponda.

Artículo Séptimo.- Los giros autorizados para desarrollar el comercio modulado en los espacios públicos en el Distrito de Villa María del Triunfo son los siguientes:

a) Diarios y Revistas.

b) Emoliente, quinua, bebidas calientes.

c) Golosinas variadas, pasteles, entre otros similares.

d) Bebidas refrescantes no alcohólicas.

e) Dulces preparados expresión del arte culinario de los departamentos del Perú.

f) Artesanías.

g) Salchipapas, sándwiches, bocaditos limeños, (anticuchos, choncholíes, y otros).

h) Paletas de Hielo (chupetes) helados

i) Lustrabotas

j) Expresiones y exposiciones artísticas que contribuyan a presentar una imagen recuperada del distrito. 
Artículo Octavo.- Los comerciantes que desarrollen los giros señalados en el artículo precedente, deberán cumplir con los siguientes requisitos:

a) Solicitud - Declaración Jurada de Comercio Informal. (Datos-croquis de ubicación).

b) Copia del DNI

c) Formar parte de una Asociación.

d) Acreditar que su actividad comercial constituye su única fuente de ingresos personal y familiar.

e) Certificado de centro de salud y/o carné de Salud, expendio de alimentos.

f) Dos fotografías tamaño carné a colores fondo blanco. g) Pago de derechos administrativos.

e) Constancia de asistencia a charlas de capacitación efectuada por la Gerencia de Desarrollo Económico.

Artículo Noveno.- La autorización para la ocupación del espacio público es de carácter excepcional, temporal por un plazo de 12 meses.

(El Peruano, 2008)

\section{Entrevistas completas}

\section{Luis Ruiz}

Ex - presidente de la Cooperativa San francisco / actualmente Socio de la cooperativa

\section{¿CÓMO FUE QUE COMENZÓ SU NEGOCIO FORMAL O INFORMAL?}

En un principio no se veía el ser formal, faltaba capacitación orientación de los diligentes y un negocio. Registrándote a la SUNAT, construyes tu empresa, para emitir boletas y facturas.

¿QUÉ PIENSA DE LOS AMBULANTES QUE SE ENCUENTRAN ALREDEDOR QUE NO ESTÁN DENTRO DE LAS LEYES DE LA SUNAT LA
MUNICIPALIDAD DE VMT? ¿LE PERJUDICA?

Al respecto de cada gestión que ha habido de los alcaldes, 4 a 5 gestiones que han pasado, no han ejercido autoridad, las 3 zonas avenidas, son zona rígida así que la autoridades tiene que hacer cumplir las leyes del comercio ambulatorio alrededor del mercado, porque está prohibido pero hacen caso omiso a los 
ambulantes porque les cobran a los ambulantes, ya que perjudica el comercio internamente, dado que hacen compiten con otros o lo venden con un precio más bajo que nosotros los comerciantes formales, roban en el peso, productos al intemperie, no es igual que tener los productos en un local construido, mejor presencia, mejor conservación de los productos.

\section{¿HA HABIDO INCIDENTES QUE LE HA PERJUDICADO DIRECTAMENTE A USTED POR LOS COMERCIANTES INFORMALES?}

A habido enfrentamiento anteriormente, ya que se le dice que no se ubiquen en las zonas alrededor del mercado, pero la gente ambulante, es de otra zona chorrillos, san juan de Lurigancho y no se puede tratar, y dejamos que la fiscalía intervenga, ya que es la función netamente de la municipalidad.

\section{Entrevista 2}

Kreysi Mohina

Socia de la Cooperativa San francisco

¿USTED CONOCÍA SOBRE QUE PAPELES SE NECESITAN PARA SER FORMALES?

En su totalidad no pero en parte sí porque mi mamá ya era formal, cuando necesite hacerlo ya sabía lo que tenía que hacer, ya sabía que llevar al contador, que tenía que pagar un derecho a la SUNAT, etc.

\section{¿QUÉ PIENSA SOBRE LOS VENDEDORES AMBULANTES QUE NO ESTÁN PAGANDO IMPUESTOS?}

Que ellos tienen mucha más ventaja que nosotros que estamos en un mercado formal primeramente lo que es el precio un vendedor ambulante no tiene casi gastos, solo el alquiler, y el alquiler de afuera de un espacio o puesto o pedacitos siempre será más cómodo que pagar en un mercado, en un mercado no solo pagas el puesto, pagas luz pagas agua, pagas todo, administración, estás sujeto a muchas reglas y tienes que cumplirlas, ellos no, por eso tienden a vender la mercadería mucho más barato entre comillas, dice la gente es más baratos pero si tú te pones a pensar si es más barato, habrá que pensarlo indudablemente porque yo te puedo decir que te vendo 3 soles y te lo estoy vendiendo a 4 , uno, dos, en ellos, su desventaja para ellos creo yo es el estar afuera implica que no tienen 
comodidad y no pueden vender de todo, porque hay mercadería que se puede malograr en la intemperie entonces no pueden vender la milanesa y si la venden lo venden mal, porque no tienen un caño donde lavarse las manos, etc. , hay ventajas y desventajas, y como digo que no debe ser así, yo pienso que ellos deben no formalizar para un inicio yo creo que puede estar permitido porque no saben pero ya ellos a veces están demasiado años en la calle, 15 a 20 años?, porque están afuera, porque realmente no tienen dinero?, eso no es la verdad, realmente ellos han hecho más dinero, por eso no se formalizan, no les conviene, están acostumbrados.

\section{¿CÓMO COMENZÓ SU NEGOCIO FORMAL O INFORMALMENTE Y PORQUE?}

Cuando inicio empiezo siendo informal pero porque yo haya vendió como ambulantes, yo comencé repartiendo, cuando quise vender al público directamente a las amas de casa yo alquile un local no, de repente al comienzo no pagaba a la SUNAT pero me fui formalizando por la necesidad ya había eso de que la SUNAT entraba a los negocios y no tenía el temor que cierren el negocio y que pierda más dinero, mejor pago lo que tengo que pagar y me evito problemas, esa fue la razón, pero yo nunca he sido ambulantes, yo siempre he pagado alquilado, he pagado un alquiler, un negocio he pagado mi licencia siempre y cuando he repartido en las tiendas, allí no, porque si tenía que dar una factura, daba la de mi mama, lo hacía como si ella lo estuviera vendiendo, no yo, como yo fuera su empleada, ante lo legal.

¿CUANDO YA LLEGÓ AL MERCADO, SI QUISO TENER TODO FORMAL?

Cuando puse la avícola, se comenzó a pagar lo que se tenía que pagar a la SUNAT a sacar la licencia, el funcionamiento de la municipalidad, ya después compre otro puesto, formal porque, porque te exige el estar en un mercado, en una cooperativa, te exige, que tú seas formal, no puedes trabajar informalmente.

\section{Entrevista 3}

Adrian Paz

Comerciante formal en el mercado San Francisco / anteriormente ambulante. 
Por la necesidad de trabajo, por falta de trabajo se vuelve independiente, en mi caso comenzó como comercio ambulatorio en los tiempos de los 80's iniciamos vendiendo en la calle vendiendo tubérculos, verduras, comenzamos de a poco con un capital de 100 soles.

\section{¿QUE LES HABÍA IMPEDIDO FORMALIZARSE?}

Los alquileres del mercado eran caro, en la calle solo pagaban los permisos del consejo y una sisa diaria de 0.20 céntimos algo así, en cambio en un puesto formal era caro más que nada pagaba alquiler

\section{¿QUE TIPO DE PROBLEMAS TUVO EN LA CALLE POR TRABAJAR DE} ESA MANERA?

Llamado desalojos, los muchos vecinos el mismo consejo, por la molestia de los vecinos, luego de 20 años, dejamos la calle, se pudieron comprar un terreno, para formar un mercado, algo de 60 personas se compró el terreno, luego de media año se levantó el mercado y ahora cada uno es dueño del stand que se vende.

\section{Entrevista 4}

Miguel Ángel Félix

Presidente Actual de la cooperativa San Francisco

¿CUANDO FUE CREADO LA COOPERATIVA SAN FRANCISCO Y CON CUÁNTOS SOCIOS CUENTA?

2 octubre del 1964, actualmente contamos con 435 asociados

¿LOS SOCIOS PASARON DE LA INFORMALIDAD A LA FORMALIDAD, FUE ESTO DIFÍCIL?

Claro, la cooperativa san francisco, primero se inició como una paradita, los primeros pobladores del distrito separaron este terreno de aproximadamente 10 mil metros para posteriormente asociarse y luego convertirlo en este gran mercado comercial

\section{¿SABÍA QUE TRAMITES HACER O LA COOPERATIVA LOS AYUDÓ PARA HACER LOS TRÁMITES PARA FORMALIZARSE?}

Entiendo que los fundadores porque nosotros somos asociados nuevos, entiendo que los asociados y los fundadores se han sacrificado mucho no ha sido fácil, ha habido una época que donde esta parte estaba todo parametrado con el 
crecimiento provisional quería ocuparlo al hacerlo vivienda entonces allí con el apoyo de otro grupo importante del distrito de villa maría se pudo sostener con el asesoramiento de también de otra gente que conocía el tema del mercado, el tema de formalizar.

¿QUÉ PIENSA DE LOS AMBULANTES QUE VENDEN ALREDEDOR DEL MERCADO SAN FRANCISCO? ¿LES AFECTA?

Enormemente, porque todos tienen derecho a trabajar, pero tienen derecho a trabajar formalmente, con un carnet de sanidad, debidamente informados, no exponga el producto de consumo al aire libre al polvo al humo que daña la salud.

Enormemente, porque afuera la gente vende producto de 3era categoría y aparte de eso, hay quejas sobre el peso y mucha gente piensa que están vendiendo productos de calidad y al precio justo, la gente compra afuera supuestamente a un precio más cómodo.

¿PORQUE CREE USTED QUE LOS AMBULANTES NO SE FORMALIZAN?

Pienso que ellos no quieren pagar impuestos. No quieren pagar local, falta de orientación también porque ha habido diferencias en otros distritos que le dan oportunidad e 1 a 2 años de ellos comprar su terreno y ellos pasar pero eso no ha ocurrido, la mayoría de la gente informal que tenemos alrededor son de otros distritos, no son ambulantes, son mayoristas. Vienen con camionetas llenas de verduras, lleno de fruta, triciclos llenos. Ambulantes se dice a la persona que trae un plástico y lo tira al suelo y vende contado sus cosas pero los que están alrededor nuestro en la avenida San José, y en la avenida Olaya son mayoristas.

USTEDES COMO COOPERATIVA CON QUIEN HABLAN SOBRE LAS LEYES DE LA SUNAT O LA MUNICIPALIDAD O COMO ES ESA PARTE DEL TRÁMITE

ustedes han visto en estos últimos días, la municipalidad ha hecho un trabajo de erradicar el comercio informal eso ha sido con resultado también por la decisión política que tiene la nueva autoridad y las coordinaciones que hemos hecho con ellos, ellos son los que regulan el comercio formal e informal ya que también acuérdese que hay asociaciones de venta de anticuchos de naranjas, son asociaciones que ellos sí están regulados, el problema está en que en forma discriminada ocupan todo una vía y eso malogra el ornato de la ciudad y eso le 
corresponde a la municipalidad en tema de SUNAT son como los contundentes de las obligaciones tributarias que tenemos

\section{¿Y PARA ESTAR DENTRO DE LA COOPERATIVA COMO SOCIO ES COMPLICADO? OSEA UNIRSE ES COSTOSO O COMPLICADO TODO ESE TRÁMITE?}

Le voy a comentar algo que con mis directivos tienen conocimiento, nosotros con la finalidad de ayudar a la autoridad, tenemos espacios en este segundo piso para que los señores que están afuera ingresen al mercado porque nosotros pensamos que un momento la municipalidad se va a cansar de mandar de 10 a 15 hombres y todo el trabajo realizado en este mes, enero que ha terminado va a ir al agua porque nuevamente van a salir, entonces la cooperativa san francisco ofrece sus espacios que tiene en el segundo piso para que ellos puedan estar comercializando.

\section{Entrevista 5}

Pedro Vílchez

Representante del área de economía y desarrollo de la Municipalidad de Villa María del Triunfo.

USTEDES QUE VEN CADA DIA LA INFORMALIDAD, ¿CUAL PIENSA QUE ES LA RAZÓN OR LA QUE SE NIEGA LA GENTE A FORMALIZARSE?

Bueno hay muchas razones, una de ellas es la falta de recursos no, su propio modo de vida, de hacer las cosas, digamos como empíricamente y también la falta de decisión a veces de las autoridades que no toman las riendas para poder encontrar este problema que tienen algunos distritos.

¿ESTA GESTIÓN QUÉ MEDIDAS ESTÁ TOMANDO CON RESPECTO A LOS AMBULANTES INFORMALES?

Estamos trabajando ahorita, en la elaboración de un proyecto de ordenanza que pretende ordenar y formalizar todo el comercio ambulatorio en todo villa María del triunfo, tenemos una ordenanza del 2008 que ya está desfasada podríamos decirlo y no cumple con las expectativas que tiene la ciudad, la ciudad ha crecido demasiado y ha crecido de una forma desordenada y ahorita estamos justo trabajando en un proyecto de ordenanza para poder encauzar y establecer unas 
zonas rígidas, algunas zonas rígidas para que esto no se desarrolle de una manera desordenada.

\section{¿LA MUNICIPALIDAD TIENE ENTRE SUS PROYECTOS BRINDAR, CAPACITAR, ASESORA PARA QUE LOS AMBULANTES SE FORMALICEN?}

Claro que sí, ese es una de las normas que estamos estableciendo en esta ordenanza, nosotros como desarrollo económico, tenemos la función de capacitar y fomentar, el desarrollo económico en todos los sectores del distrito y uno de ellos es brindándoles capacitaciones con alianzas estratégicas, con empresas, con ONGs, con distintas entidades pues que puedan darle una buena capacitación para que puedan tener una mejor calidad de vida y puedan extender sus productos de alimentos.

\section{¿TIENEN ALGÚN ESTABLECIMIENTO DONDE PUEDAN TRABAJAR FORMALMENTE LOS AMBULANTES?}

No, local no contamos con locales, como bien dice es comercio ambulatorio ellos están en la vía pública lo que nosotros hacemos es establecer parámetros dentro de la vía pública para que en ciertos puntos pueda solamente es establecer parámetros dentro de la vía para que ciertos puntos puedan expender sus productos, no en cualquier parte, eso lo vamos a establecer en la ordenanza, solamente son puntos específicamente establecidos.

\section{¿QUE TANTO AFECTA EL TRABAJO AMBULATORIO PARA UNA MEJORA DEL DISTRITO?}

En qué afecta el trabajo ambulatorio, el trabajo ambulatorio afecta mucho al comerciante formal, si ustedes saben en todos los distritos hay negocios que cuentan licencia de funcionamiento, pagan sus impuestos, pagan todos sus servicios, mientras que el comercio ambulatorio no, esto merma en ingreso al comercio formal.

\section{¿AL DISTRITO?}

Cómo afecta, nos genera desorden, nos genera residuos sólidos, incrementa la basura y la municipalidad deja de percibir ingresos por parte de ellos, lo que la municipalidad trata de promover, para mejorar esto, es que estos comerciantes en un pequeño a corto plazo puedan volverse formales y luego a lo largo tener un 
negocio propio en un establecimiento con las licencias de funcionamiento con certificado de fuerza civil y que ya no estén en la vía pública.

\section{¿EL DINERO QUE USTEDES RECAUDAN DE LOS TRIBUTOS COMERCIALES A DONDE ESTÁN DESTINADOS EXACTAMENTE?}

He bueno eso se destina a distintas formas, se destina para pago de personal, para servicios, servicios básicos, luz agua teléfono, para combustibles de las maquinarias y diversas cosas, también se destinan para las obras del distrito, las obras que están programadas.

\section{¿QUÉ PIENSA USTED DEL HECHO QUE LOS COMERCIANTES INFORMALES, EVADAN SUS TRIBUTOS?}

Como le dije en la pregunta anterior esto perjudica al distrito, porque deja de recaudar impuestos, y los impuestos para poder brindar un mejor servicio a la población, nosotros dejamos de recibir impuestos, dejamos de dar nuestro servicios a la población, eso sería el inconveniente.

\section{¿QUÉ PODEMOS HACER LOS CIUDADANOS CON RESPECTO A LOS AMBULANTES?}

Generalmente lo que se recomienda es ir o solicitar un servicio de manera formal, siempre preferimos que vaya a un mercado, que vayan a las tiendas, pero lamentablemente el comercio ambulatorio, digamos que es la solución al problema diario de la misma población, que sugeriría, que evitemos consumir tanto comercio ambulatorio, que consumimos más, comercio formal.

\section{¿PORQUE A LA HORA DE FISCALIZACIÓN USTEDES TIENEN QUE LLEVARSE LOS PRODUCTOS DE LOS COMERCIANTES?}

Lo que pasa no es que nos lo llevemos, eso se retiene provisionalmente no, eso está establecido en las ordenanzas, si el ambulante no cumple con lo que dice la ordenanza, la municipalidad tiene que venir y en modo de custodia retener el producto mientras se pague la multa o se ordene no, esto generalmente sucede en los comerciantes ambulantes que no están debidamente registrados, los que están registrados o están trabajando en una zona autorizada no tienen ese problema.

¿CUALES SON LOS REQUISITOS PARA FORMALIZARSE DE UN AMBULANTE? 
Los requisitos son presentar una solicitud por mesa de partes, esa solicitud tiene debe incluir, tiene carácter de declaración jurada, tiene que incluir el número de DNI, dirección, dirección del establecimiento, adjuntar un croquis de la ubicación, pertenecer a una asociación, esta asociación debe estar debidamente registrada con su RUS en la municipalidad y pasar previamente una evaluación socioeconómica que indique esta actividad es su único medio o sustento de ingreso familiar.

¿SE TIENE QUE HACER ALGÚN PAGO?

Sí, hay una tasa que se paga de acuerdo que establece el TUPA, es todo un procedimiento administrativo.

¿CUAL ES EL PAGO QUE SE HACE?

El pago es aproximadamente 90 soles para hacer todo el trámite.

\section{¿HAN HECHO ALGUNAS CAMPAÑAS PARA AFRONTAR LA INFORMALIDAD?}

Actualmente no, como ustedes sabrán estamos en un nuevo gobierno entrante pero estamos dentro de nuestros planes de trabajo, hacer campañas de sensibilización, campañas de orientación, ya tenemos reuniones continuas con los ambulantes para poder ver la problemática, ellos están dispuestos a ordenarse porque está totalmente desordenado el distrito y se trata de darle una solución al problema.

\section{¿USTED SABE CUÁNTOS AMBULANTES HAY APROXIMADAMENTE EN EL DISTRITO?}

Aproximadamente debemos tener 7000 ambulantes

¿Y CUÁNTOS DE ELLOS SON FORMALES?

Aún no lo sabemos eso estamos recién recopilando la información, lo tenemos todo en archivos tendremos menos de 60 días en esta gestión, y estamos comenzando a armar nuevamente todo.

\footnotetext{
¿QUÉ PIENSA USTED PORQUE LOS AMBULANTES NO SE FORMALIZAN?

Porque es un medio de trabajo rápido y fácil, mucha gente agarra sus productos o lo que tiene a la mano y sale y lo vende a la esquina de su casa, ese proceso de formalización es un trabajo que nos compete a nosotros, darle la capacitación, darle la orientación, darle las recomendaciones, mucha gente sale y
} 
por la misma necesidad empieza a vender lo que se le ocurre de alguna manera improvisada

\section{¿EL SISA AÚN SE SIGUE COBRANDO?}

No, actualmente no, estamos justo haciendo la evaluación de todo eso, el sisa se cobraba 1 sol diario, actualmente justo estamos actualizando esta currícula de, que está complicado en el distrito de Villa María, 7000 ambulantes es bastante, imagínese quitar el puesto de trabajo a 7000 personas. Ahorita, un dolor de cabeza, así que es un trabajo que se tiene que trabajar con mucho cuidado

\section{¿TODO VILLA MARIA ES ZONA RÍGIDA?}

no, es por partes, nosotros estamos poniendo en esta ordenanza como zonas rígidas, las vías metropolitanas que están bajo la jurisdicción de lima metropolitana, parques plazas, mercados, colegios, instituciones educativas, instituciones del estado, como puede ser, municipalidades, comisarías, juzgados, todas esas zonas, estamos declarando como zonas rígidas, alrededor de ellos no puede haber nada de comercio ambulatorio.

Esas van a ser las zonas reguladas, eso que le he dicho son las zonas rígidas, ahora las zonas reguladas son, que la municipalidad con previa evaluación va a determinar dónde se puede vender el comercio ambulatorio

\section{¿PUEDEN VENDER DIVERSOS PRODUCTOS?}

eso también está establecido en la ordenanza, nosotros trabajos de esta ordenanza en base de lo que dice lima metropolitana y lima metropolitana establece giros para el comercio ambulatorio, por eso les hablaba del comercio ambulatorio modulado, que entra allí, anticucho, picarones, mollejas, todos los derivados de estos, llaves, cerrajerías, artesanías, también es otro de los rubros, lustrabotas, desayunos, emolienteros, que ellos tienen su propia ley y los canillitas y los que venden periódico.

Hay rubros que no son considerados como comercio ambulatorio, hay cosas que si se van a tener que erradicar definitivamente. 
TRABAJO DE CAMPO

Domingo 20 de enero $-1 \mathrm{pm}$
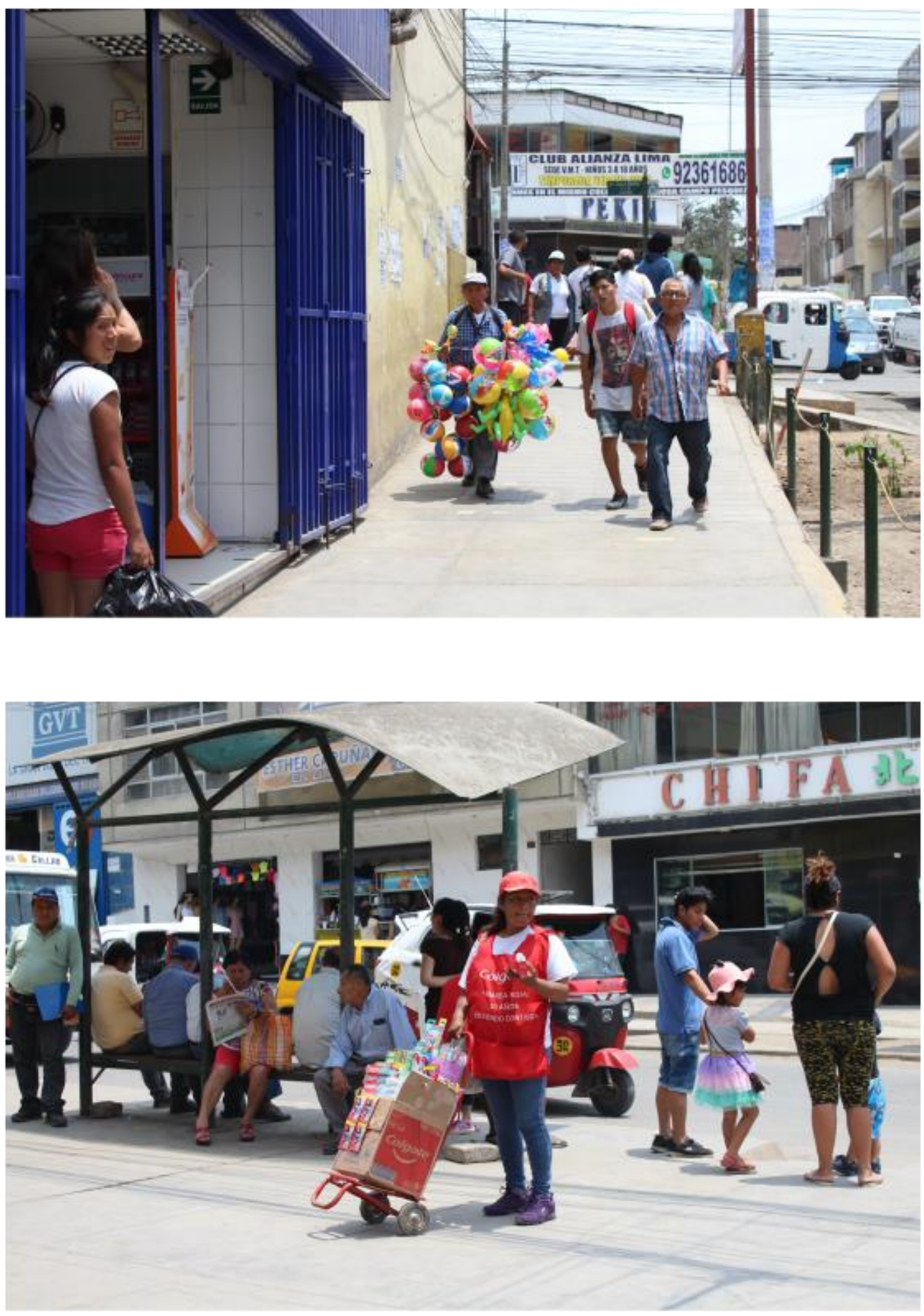

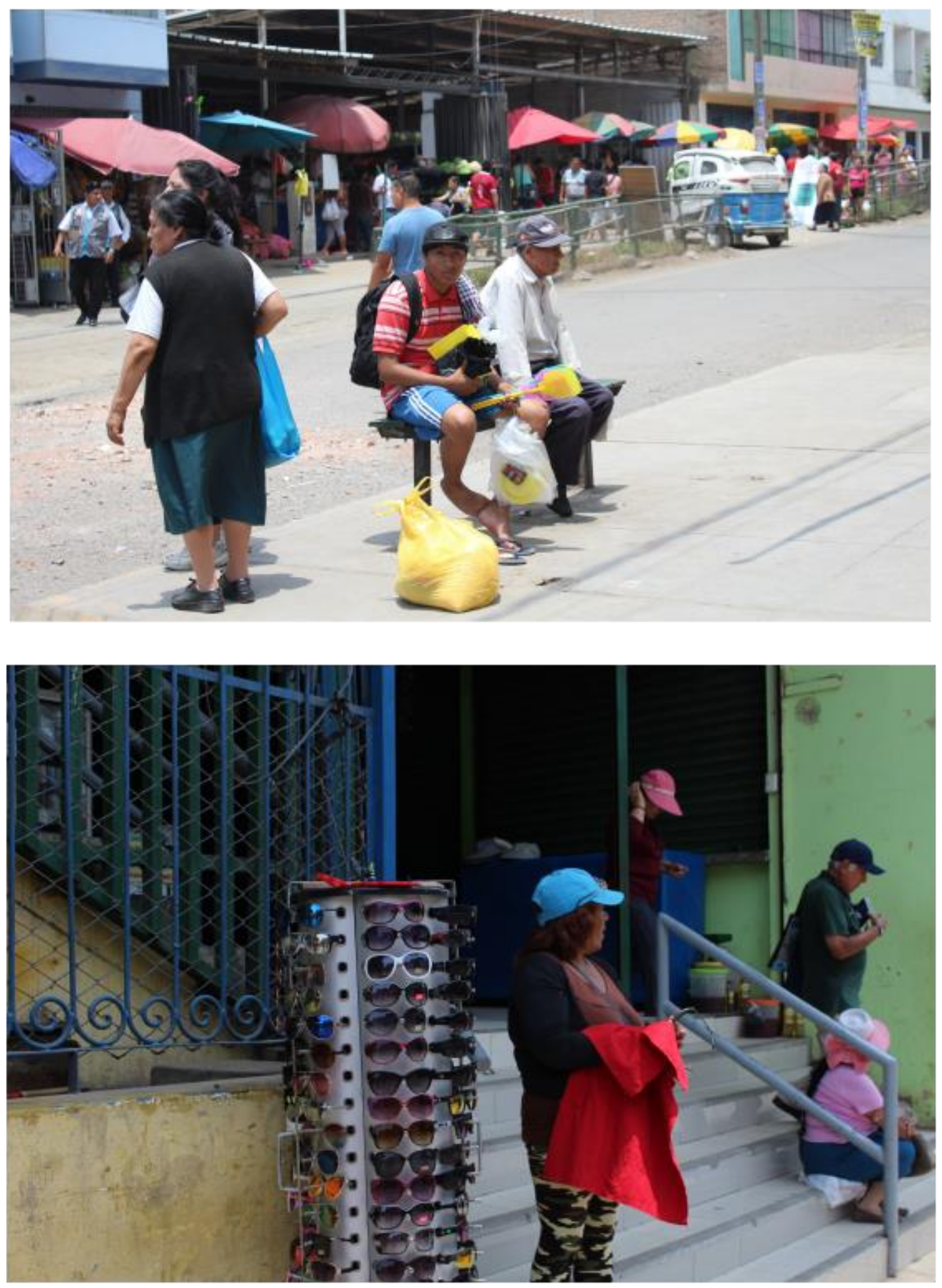
Lunes 28 de enero -5 pm
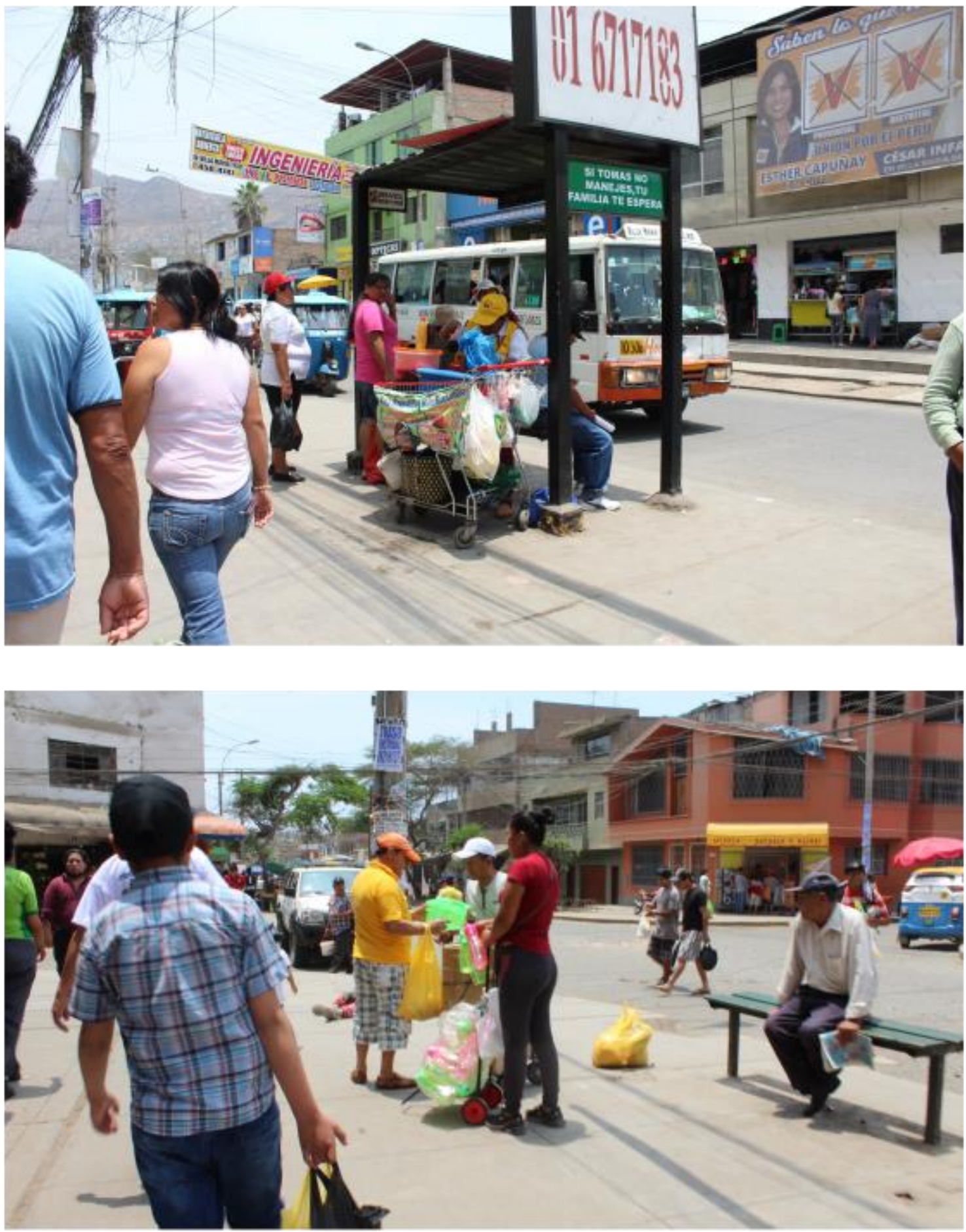

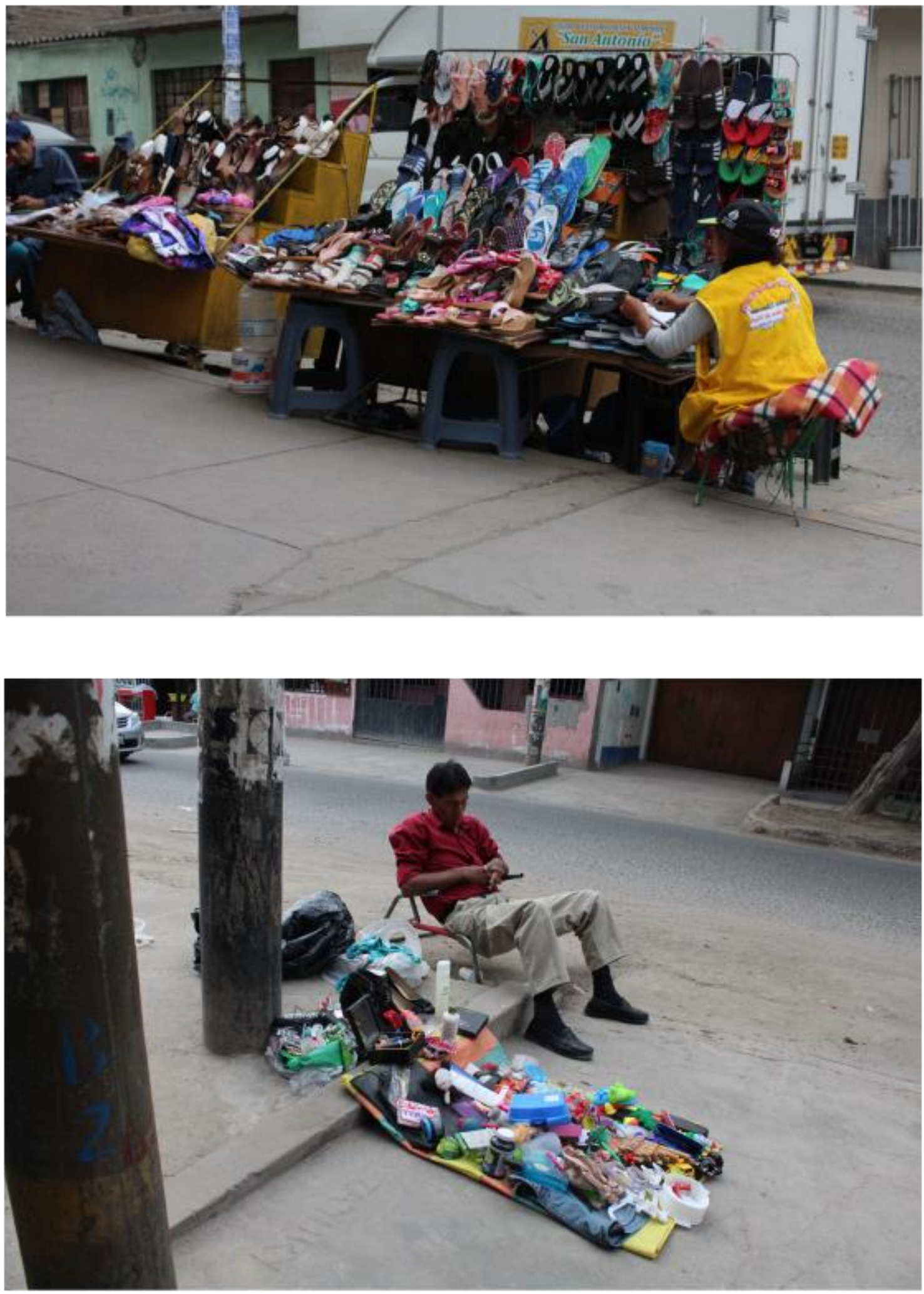
Lunes 11 de Febrero - 1pm
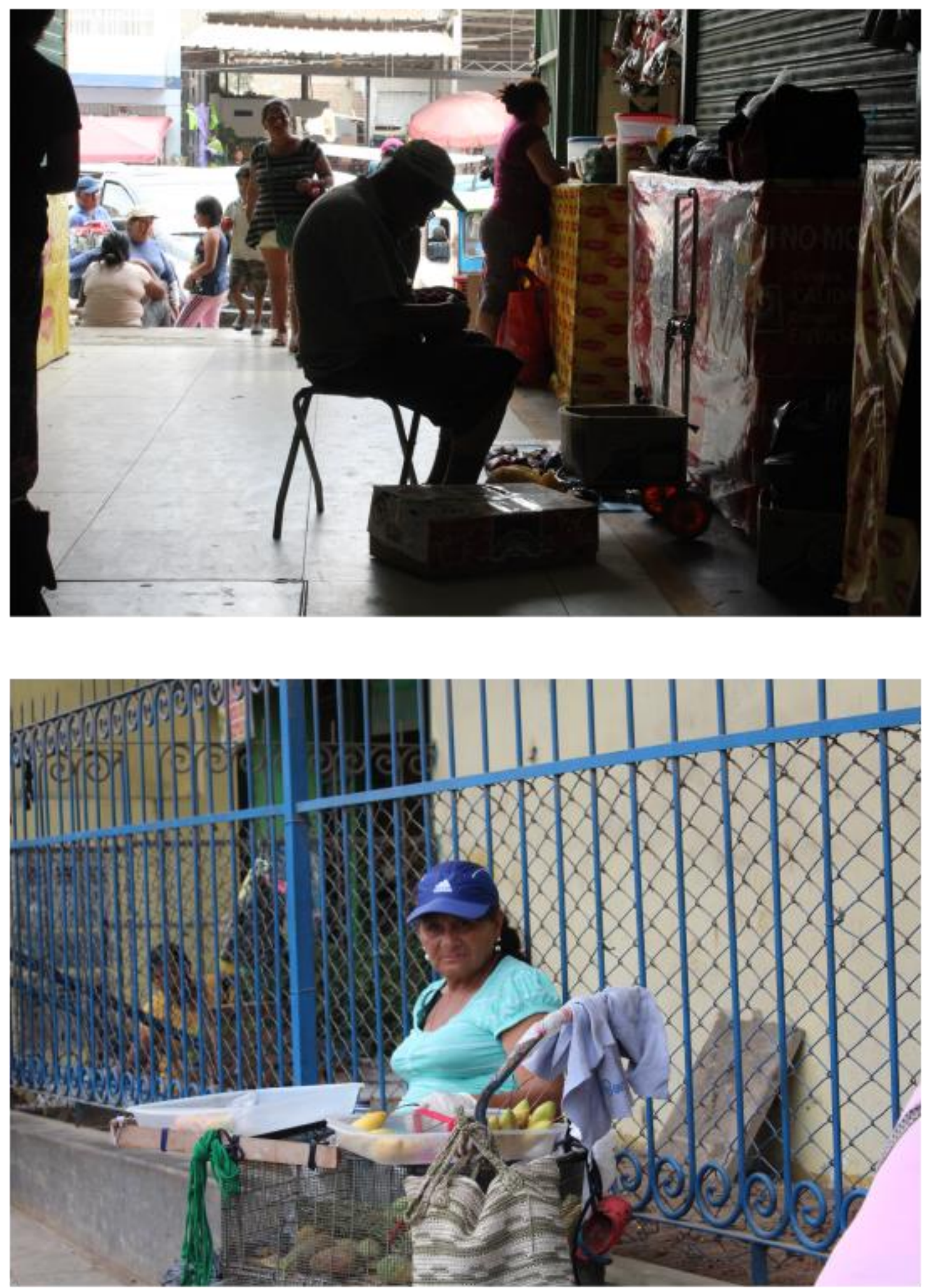

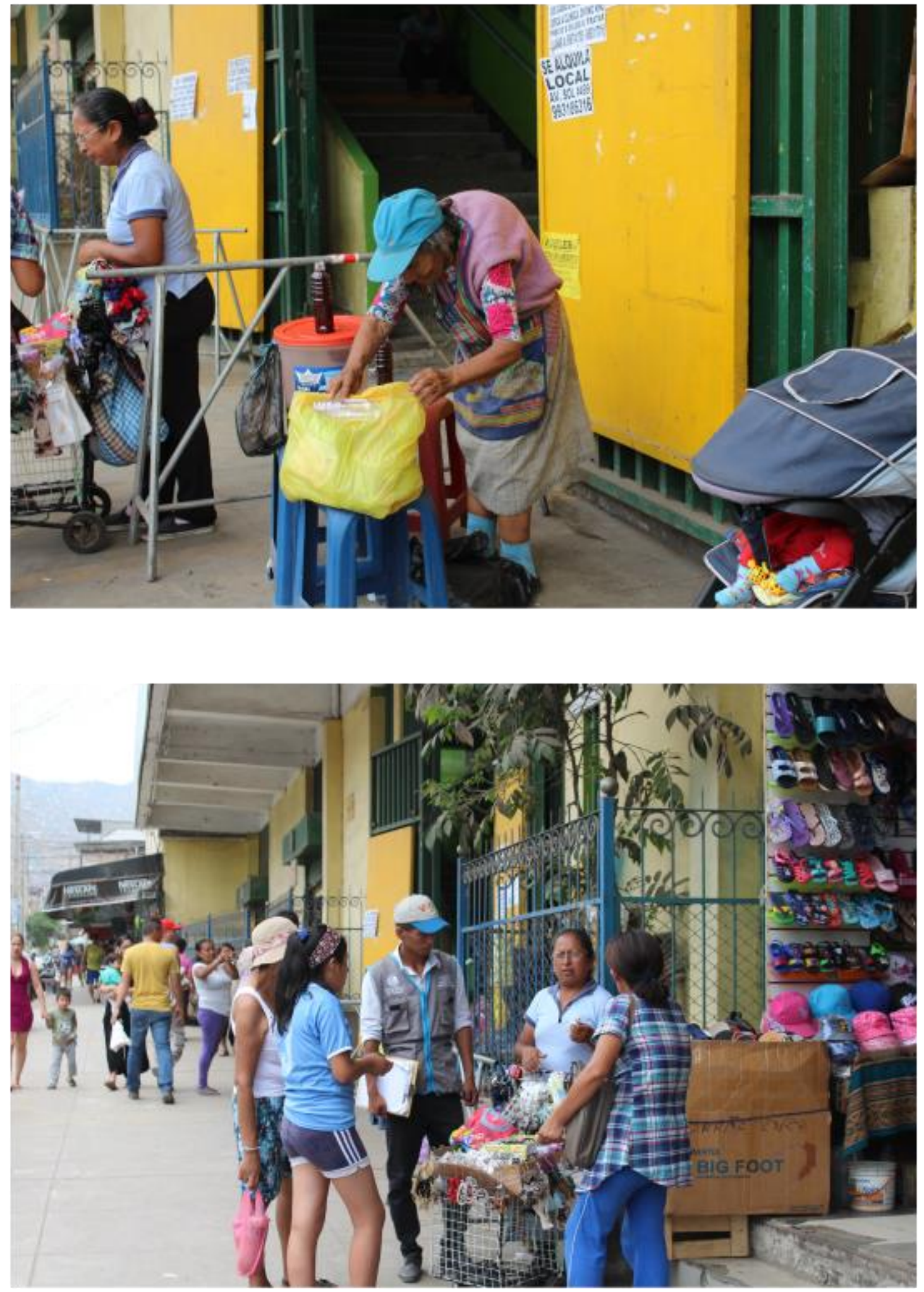
Viernes 15 de Febrero - 2pm
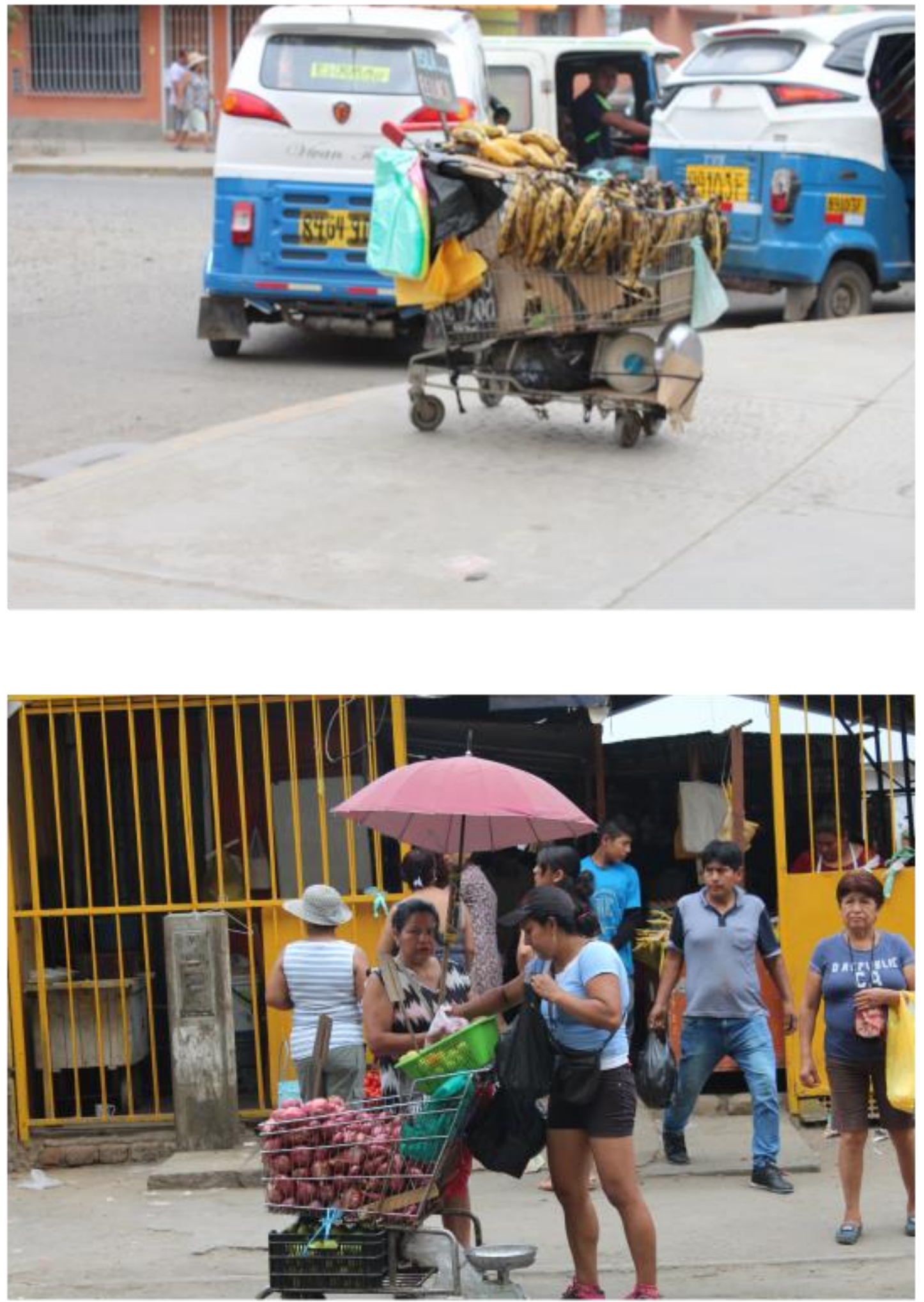

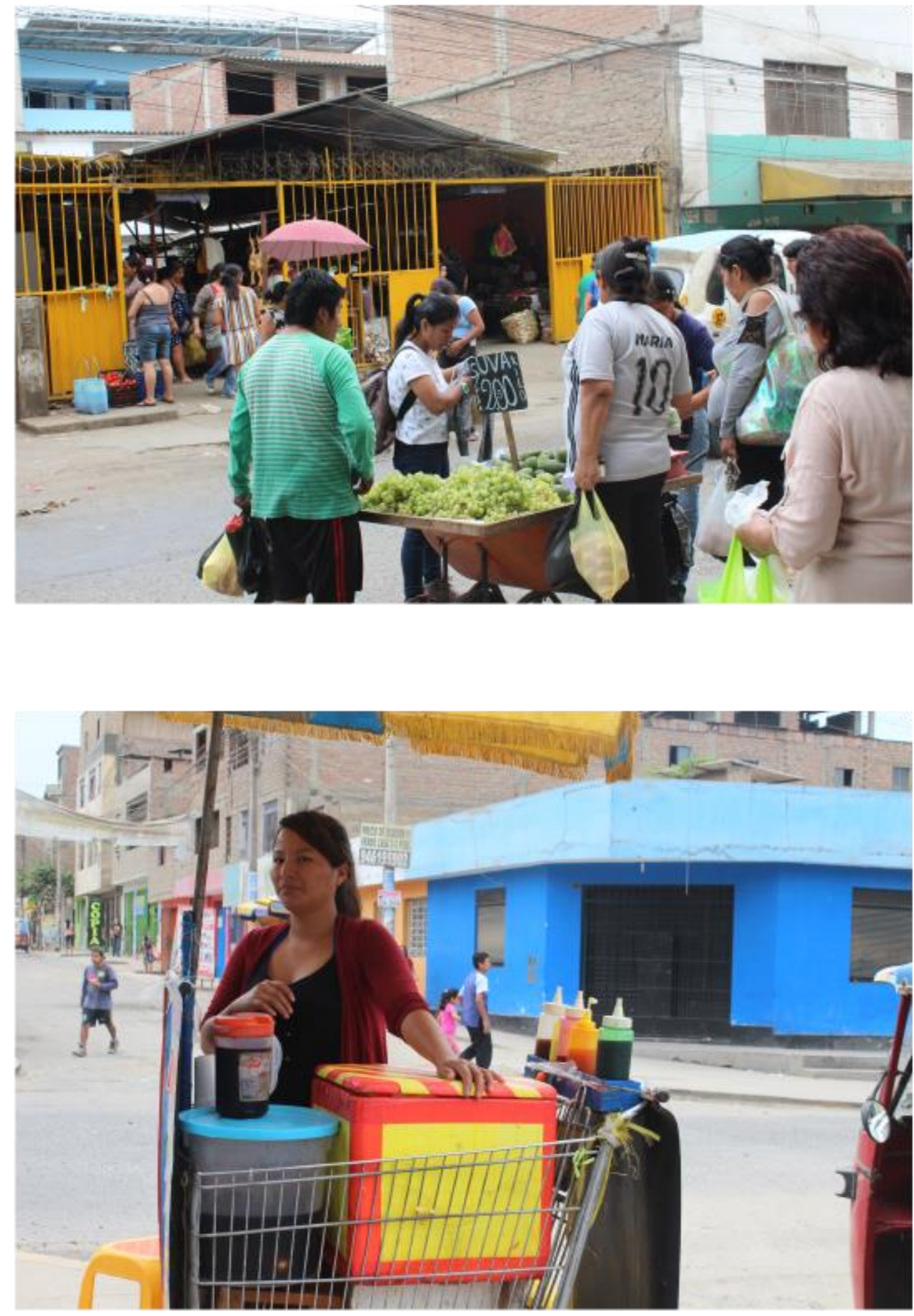


\section{BIBLIOGRAFÍA}

BBVA Observatorio Económico Perú 2017 Informalidad Laboral y algunas propuestas para reducirla (Recuperado 22 de febrero del 2019) https://www.bbvaresearch.com/wp-content/uploads/2017/01/Observatorioinformalidad-laboral1.pdf

Diario Correo 2015 (Recuperado el 22 de febrero del 2019)

http://diariocorreo.pe/ciudad/esta-permitido-que-fiscalizadores-arrebaten-bienes-avendedores-ambulantes-634099/

Campaña sí a la Formalidad 2014 Colombia (Recuperada el 25 de febrero 2019) http://www.camaraarmenia.org.co/contenido-index-id-138.htm

Crezcamos juntos México (Recuperado el 25 de Junio 2017)

https://www.gob.mx/crezcamosjuntos/que-hacemos\#acciones

Ministerio de economía y finanzas Perú (Recuperado 16 de febrero del 2019)

https://www.mef.gob.pe/es/sistema-tributario-lineamientos-de-politica-tributaria/delgobierno-central

La economía informal, causas consecuencias y ejes de solución OIT 2014 (Recuperado el 20 de febrero del 2019)

http://centrum.pucp.edu.pe/oci/presentaciones/10-APERHU - Roberto Villamil.pdf La Economía de Perú y los problemas del desarrollo (Recuperado el 25 de Febrero del 2019)

https://www.celag.org/peru-enigma-crecimiento-economico-latinoamericano/

Periódico Perú 212017 (Recuperado el 22 de febrero del 2019)

http://peru21.pe/actualidad/chorrillos-detienen-dos-agentes-serenazgo-extorsionarambulantes-2280141

Periódico El Comercio 2017 (Recuperado el 25 de febrero del 2019)

http://elcomercio.pe/economia/peru/bbva-research-informal-hay-peru-estudio-232073

Portal de Noticias Gaceta Ucayalina, Enero 2019

https://www.gacetaucayalina.com/2019/01/el-comercio-informal-calles-sinambulantes-en-trujillo.html

Producción y Empleo informal en el Perú INEI 2007 (Recuperado 22 de febrero del 2019) 
https://www.inei.gob.pe/media/MenuRecursivo/publicaciones digitales/Est/Lib1154/li bro.pdf

Revista salud pública 2012 (Recuperado 15 de febrero del 2019)

http://docplayer.es/2970767-Condiciones-de-trabajo-y-salud-de-vendedores-

informales-estacionarios-del-mercado-de-bazurto-en-cartagena.html

Soto, H (1989) El otro Sendero

Entrevista al Sr. Luis Ruiz Expresidente de la Cooperativa de Servicios Especiales

San Francisco Ltda., actualmente socio y comerciante formal del mercado San

Francisco

Entrevista a la Sra. Kreysi Mohina Socia de la Cooperativa de Servicios Especiales

San Francisco Ltda. y comerciante formal del mercado San Francisco

Entrevista al Sr. Adrian Paz Comerciante formal del mercado San Francisco

Entrevista a la Sra. Delia Pacheco Ambulante en venta de ropa en los alrededores

del mercado San Francisco

Entrevista al Sr. Miguel Ángel Félix Presidente Actual de la Cooperativa de Servicios Especiales San Francisco Ltda.

Entrevista al Sr. Pedro Vílchez Representante de Gerencia de Desarrollo Económico Local de la Municipalidad de Villa María del Triunfo 